\title{
Bioinformatics analysis of potential key genes and mechanisms in type 2 diabetes mellitus
}

Basavaraj Vastrad ${ }^{1}$, Chanabasayya Vastrad $*^{2}$

1. Department of Biochemistry, Basaveshwar College of Pharmacy, Gadag, Karnataka 582103, India.

2. Biostatistics and Bioinformatics, Chanabasava Nilaya, Bharthinagar, Dharwad 580001, Karnataka, India.

* Chanabasayya Vastrad

channu.vastrad@gmail.com

Ph: +919480073398

Chanabasava Nilaya, Bharthinagar,

Dharwad 580001 , Karanataka, India 


\begin{abstract}
Type 2 diabetes mellitus (T2DM) is etiologically related to metabolic disorder. The aim of our study was to screen out candidate genes of T2DM and to elucidate the underlying molecular mechanisms by bioinformatics methods. Expression profiling by high throughput sequencing data of GSE154126 was downloaded from Gene Expression Omnibus (GEO) database. The differentially expressed genes (DEGs) between T2DM and normal control were identified. And then, functional enrichment analyses of gene ontology (GO) and REACTOME pathway analysis was performed. Protein-protein interaction (PPI) network and module analyses were performed based on the DEGs. Additionally, potential miRNAs of hub genes were predicted by miRNet database . Transcription factors (TFs) of hub genes were detected by NetworkAnalyst database. Further, validations were performed by receiver operating characteristic curve (ROC) analysis and real-time polymerase chain reaction (RT-PCR). In total, 925 DEGs were identified in T2DM, including 447 up regulated genes and 478 down-regulated genes. Functional enrichment analysis results showed that up regulated DEGs were significantly enriched in defense response, neutrophil degranulation, cell adhesion and extracellular matrix organization. The top 10 hub genes, JUN, VCAM1, RELA, U2AF2, ADRB2, FN1, CDK1, TK1, A2M and ACTA2 were identified from the PPI network, modules, miRNA-hub gene regulatory network and TF-hub gene regulatory network. Furthermore, ROC analysis and RT-PCR revealed that JUN, VCAM1, RELA, U2AF2, ADRB2, FN1, CDK1, TK1, A2M and ACTA2 might serve as biomarkers in T2DM. Bioinformatics analysis is a useful tool to explore the molecular mechanism and pathogenesis of T2DM. The identified hub genes may participate in the onset and advancement of T2DM and serve as therapeutic targets.
\end{abstract}

Keywords: biomarker; differentially expressed genes; type 2 diabetes mellitus; bioinformatics; protein-protein interaction network 


\section{Introduction}

Type 2 diabetes mellitus (T2DM) is the most common chronic metabolic disorder in adults and its affects more than $90 \%$ people worldwide [1]. The incidence rate of T2DM is high, which vigorously affects the patient's health. T2DM can affect the brain [2], kidney [3], eyes [4] and heart [5]. Numerous risk factors might affect T2DM progression, including genetic [6], environmental [7] metabolic [8] risk factors, obesity [9] and hypertension [10]; however, how these factors affect the progression of T2DM requires further investigation and no effective treatment has been advanced for the relief of T2DM. In addition, molecular biology investigation have identified numerous biomarkers and signaling pathways that contribute to T2DM, including the OCT1 [11], TNF- $\alpha$ [12], TCF7L2 [13], KCNJ11 [14], SDF$1 \beta$ [14], EDNRB [15], NOS3 [15], PI3K/AKT pathway [16], IL-6 signalling pathways [17], Wnt signaling pathway [18], insulin signaling [19] and NF- $\kappa B$ signaling pathway [20]. Further investigation into the molecular events linked with T2DM progression is required.

With the advancement of molecular biological and pathological techniques, a range of markers are considered powerful tools for searching diagnostic and predictive biomarkers, especially in the therapies targeting T2DM. Expression profiling by high throughput sequencing, efficient and large-scale techniques for gaining genetic data, have been widely performed to collect and to study Expression profiling by high throughput sequencing data in T2DM. These high throughput sequencing studies develop a novel approach for identifying T2DM related genes and implement encouraging expectation for molecular prediction and therapeutic targets [21].

In the current investigation, the expression profiling by high throughput sequencing data of GSE154126 [22] was downloaded from Gene Expression Omnibus (GEO, http://www.ncbi.nlm.nih.gov/geo/) [23] to screen the differentially expressed genes (DEGs) between T2DM and normal control. Next, the DEGs were analyzed using a bioinformatics approach. To identify the enriched biological functions and pathways of DEGs, the Gene Ontology (GO) and REACTOME pathway enrichment analysis of DEGs were performed. Subsequently, functional enrichment, protein-protein interaction (PPI) networks construction, module analyses and miRNA-hub regulatory gene network 
construction and TF-hub regulatory gene network construction were performed to determine the significant pathogenic genes and their key pathways involved in the mechanism of occurrence and progression of T2DM. Hub genes were validated using the receiver operating characteristic curve (ROC) analysis and RT-PCR. These results may provide information for subsequent experimental studies of T2DM, and contribute to the understanding of the molecular mechanisms underlying the advancement of T2DM.

\section{Material and Methods}

\section{RNA sequencing data}

The expression profiling by high throughput sequencing of GSE154126 was downloaded from the GEO database. The data were produced based on the GPL11154 platform Illumina HiSeq 2000 (Homo sapiens). The GSE154126 dataset contained 1276 samples, including 508 samples of T2DM samples and 768 normal control samples.

\section{Identification of DEGs}

The limma package [24] in R Bioconductor was used to identify DEGs between T2DM samples and normal control samples. The P-values of DEGs were calculated using a t-test in $\mathrm{R}$ with the limma package. $\mathrm{P}$ value $<0.05,|\log \mathrm{FC}|>$ 0.63 for up regulated genes and $|\log \mathrm{FC}|<-1.99$ for down regulated genes were set as the cutoff criterion for statistically significant DEGs. In this investigation, ggplot2 and the gplots in R package were used to plot the volcano diagrams and heat map of the DEGs, respectively.

\section{Gene Ontology (GO) and REACTOME pathway enrichment analysis}

Gene Ontology (GO) (http://geneontology.org/) [25] and REACTOME (https://reactome.org/) [26] pathway enrichment analyses of T2DM DEGs were performed using ToppGene (ToppFun) (https://toppgene.cchmc.org/enrichment.jsp) [27]. GO terms of biological processes (BP), cellular components (CC), and molecular functions (MF) linked with a p-value $<0.05$ were considered to be significantly enriched.

\section{PPI network construction and module analysis}


The online IntAct interactome (https://www.ebi.ac.uk/intact/) [28] database was used to identify potential interaction among the common DEGs, and a confidence score of $\geq 0.4$ was set as the threshold. Cytoscape software, version 3.8.2 (www.cytoscape.org) [29] was used to visualize the PPI network of common DEGs. The Network Analyzer plug-in was used to calculate node degree [30], betweenness centrality [31], stress centrality [32] and closeness centrality [33], that were to filter hub genes of PPI. The PEWCC1 (http://apps.cytoscape.org/apps/PEWCC1) [34] was used to search modules of the PPI network and the default parameters (Degree cutoff $\geq 10$, node score cutoff $\geq 0.4$, K-core $\geq 4$, and $\max \operatorname{depth}=100$.) were set in the functional interface of Cytoscape software.

\section{MiRNA-hub gene regulatory network construction}

miRNet database (https://www.mirnet.ca/) [35] for miRNA-hub gene regulations, through which regulatory associations between hub genes and miRNAs can be identified. This study inputted the overlapped hub genes into the database to examine the regulatory association pairs between miRNAs and hub genes. Based on the data this study obtained, miRNA-hub gene regulatory network was constructed and visualized by Cytoscape 3.8.2 software to show the overlapped miRNAs and hub genes. Therefore, these miRNAs and hub genes might play a potential role in the pathogenesis and treatment of T2DM.

\section{TF-hub gene regulatory network construction}

NetworkAnalyst database (https://www.networkanalyst.ca/) [36] for TF-hub gene regulations, through which regulatory associations between hub genes and TFs can be identified. This study inputted the overlapped hub genes into the database to examine the regulatory association pairs between TFs and hub genes. Based on the data this study obtained, TF -hub gene regulatory network was constructed and visualized by Cytoscape 3.8.2 software to show the overlapped TFs and hub genes. Therefore, these TFs and hub genes might play a potential role in the pathogenesis and treatment of T2DM.

Validation of hub genes by receiver operating characteristic curve (ROC) analysis 
Genes in the PPI network identified by Network Analyzer plug-in were selected as candidate hub genes. To evaluate the role of candidate genes in the diagnosis of T2DM, receiver operating characteristic (ROC) curve analysis was organize in RStudio with pROC package [37]. The genes with area under curve (AUC) $>0.8$ was considered as hub genes of T2DM.

\section{Detection of the mRNA expression of the hub genes by RT-PCR}

Pancreatic beta cell line MIN6 culture treated with streptozotocin for T2DM and pancreatic beta cell line MIN6 culture for normal control were used to examine the mRNA expression of the hub genes in T2DM and normal control. Pancreatic beta cell line MIN6 were maintained in $15 \%$ fetal calf serum, $50 \mathrm{mg} / \mathrm{l}$ streptomycin and $75 \mathrm{mg} / \mathrm{l}$ penicillin sulphate in Dulbecco's modified Eagle's medium (DMEM). Pancreatic beta cell line MIN6 were cultured at $37{ }^{\circ} \mathrm{C}$ and $\mathrm{CO}_{2}$ concentration is $5 \%$. Total RNA was isolated from pancreatic beta cell line MIN6 culture treated with streptozotocin and pancreatic beta cell line MIN6 culture using TRI Reagent (Sigma, USA) according to the instructions. RNA samples were reverse transcribed into cDNA by reverse transcription kit (Thermo Fisher Scientific, Waltham, MA, USA). RT-PCR analysis was performed QuantStudio 7 Flex realtime PCR system (Thermo Fisher Scientific, Waltham, MA, USA). The set of primers used in the investigation is listed in Table 1.The experiment was repeated in triplicate. PCR profiles used in this investigation were: denaturing for $10 \mathrm{~min}$ at $95^{\circ} \mathrm{C}$, annealing for $15 \mathrm{sec}$ at $95^{\circ} \mathrm{C}$, and extension for $10 \mathrm{sec}$ at $72^{\circ} \mathrm{C}$. PCR was carried out for 30 cycles. The relative value of the hub gene was normalized to those of $\beta$-actin through the $2^{-\Delta \Delta \mathrm{Ct}}$ calculation [38].

\section{Results}

\section{Identification of DEGs}

Standardization of the expression profiling by high throughput sequencing results from GSE154126, DEGs were identified. A total of 925 differentially expressed genes including 447 up regulated genes and 478 down regulated genes were detected and are listed in Table 2. The results were validated with a volcano plot of all up regulated genes and down regulated genes (Fig.1). Fig. 2 shows the DEG expression heat map. 


\section{Gene Ontology (GO) and REACTOME pathway enrichment analysis}

GO enrichment analysis showed that the DEGs were mainly involved in defense response, secretion, secretory vesicle, golgi apparatus, identical protein binding, transmembrane transporter activity, cell adhesion, localization of cell, extracellular matrix, intrinsic component of plasma membrane, structural molecule activity and signaling receptor binding, and are listed in Table 3. REACTOME pathway enrichment analysis revealed that the DEGs were mainly enriched in the neutrophil degranulation, innate immune system, extracellular matrix organization and diseases of glycosylation, and are listed in Table 4.

\section{PPI network construction and module analysis}

The PPI network of DEGs was constructed with 7195 nodes and 16541 edges (Fig.3). The node degree, betweenness centrality, stress centrality and closeness centrality methods were performed to calculate the top ranking hub genes. The results revealed 10 genes identified as hub genes, including JUN, VCAM1, RELA, U2AF2, ADRB2, FN1, CDK1, TK1, A2M and ACTA2, and are listed Table 5. PEWCC1 was used to identify the two significant cluster modules in the PPI network and the top modules were selected (Fig.4A and Fig.4B). Gene Ontology (GO) and REACTOME pathway enrichment analysis revealed that the module 1 (48 nodes and 104 edges) and module 2 (30 nodes and 92 edges) were mainly enriched in cytokine signaling in immune system, identical protein binding, neutrophil degranulation, golgi apparatus, innate immune system, extracellular matrix organization, axon guidance, cell adhesion, platelet activation, signaling and aggregation, diseases of glycosylation, hemostasis, extracellular matrix, localization of cell and structural molecule activity.

\section{MiRNA-hub gene regulatory network construction}

The miRNA-hub gene regulatory network was shown in Fig. 5, consisting of 2807 nodes and 21728 interactions. MiRNAs includes hsa-mir-1255b-5p, hsa-mir-499a5p, hsa-mir-200a-3p, hsa-mir-449c-5p, hsa-mir-520a-5p, hsa-mir-410-3p, hsa-mir3941, hsa-mir-181d-3p, hsa-mir-181c-5p and hsa-mir-708-5p were with the highest connectivity target genes, targeting 10 hub genes (up regulated: MRPL12, RAB5C, VCAM1, HIF1A and CLU; down regulated: CDK1, CHEK1, TK1, KIT and 
TOP2A) and are listed in Table 6. TF-hub gene regulatory network construction

The TF-hub gene regulatory network was shown in Fig. 6, consisting of 625 nodes and 10244 interactions. TFs includes VDR, BACH1, TFCP2L1, HOXC9, GATA2, TBX3, ATF3, GATA4, PAX6 and FOXP1 were with the highest connectivity target genes, targeting 10 hub genes (up regulated: JUN, POLR2A, HIF1A, MRPL12 and U2AF2; down regulated: RPTOR, FN1, ANLN, MME and HEY1) and are listed in Table 6.

Validation of hub genes by receiver operating characteristic curve (ROC) analysis

Validate the expression of these 10 genes in T2DM and performed ROC analysis in RStudio with pROC package. The analysis results were available in Fig.7. Ten genes (JUN, VCAM1, RELA, U2AF2, ADRB2, FN1, CDK1, TK1, A2M and ACTA2) with AUC more than 0.90 were considered as hub genes, indicating that they have the capability to diagnose T2DM patients with excellent specificity and sensitivity.

\section{Detection of the mRNA expression of the hub genes by RT-PCR}

To further verify the expression level of hub genes in T2DM (pancreatic beta cell line MIN6 culture treated with streptozotocin) and normal (pancreatic beta cell line MIN6 culture), RT-PCR was performed to calculate the mRNA levels of the ten hub genes identified in the present study (JUN, VCAM1, RELA, U2AF2, ADRB2, FN1, CDK1, TK1, A2M and ACTA2) in T2DM. As illustrated in Fig. 8, the expression of JUN, VCAM1, RELA, U2AF2 and ADRB2 were significantly up regulated in T2DM compared with normal, while FN1, CDK1, TK1, A2M and ACTA2 were significantly up regulated in T2DM compared with normal. The current RT-PCR results were in line with the previous bioinformatics analysis, suggesting that these hub genes might be associated to the molecular mechanism underlying T2DM.

\section{Discussion}

T2DM is a complex metabolic disorder characterized by defective glucose uptake in muscle and fat, varied glucose-induced insulin secretion, and heightened hepatic 
glucose production. It is largely ascribed to insulin resistance and leads in a heavy health and economic burden. Therefore, it is important to study the molecular mechanism of T2DM. In this investigation, we tried to identify the important genes related to T2DM by comparing the differences in expression profiling by high throughput sequencing between the T2DM and normal controls. A total of 925 DEGs (447 up regulated genes and 478 down regulated genes) were screened between T2DM and control samples. Emmens et al [39] found that PENK (proenkephalin) expression was up regulated in cardiovascular diseases, but this gene might be responsible for progression of T2DM. Recent studies have proposed that the SAA1 [40], SUCNR1 [41], CRP (C-reactive protein) [42], APCS (amyloid P component, serum) [43], PCK1 [44], IGF2BP3 [45], POSTN (periostin) [46] and COL6A3 [47] are associated with progression of T2DM. CARTPT (CART prepropeptide) [48], SEMA3C [49] and TDO2 [50] were proved to participate in the development of obesity, but these genes might be linked with progression of T2DM. SOX11 is associated with progression of neurological disorders [51], but this gene might be liable for advancement of T2DM.

The functional enrichment analysis indicated that the DEGs were primarily involved in the defense response, secretory vesicle, identical protein binding, cell adhesion, extracellular matrix, structural molecule activity, neutrophil degranulation and extracellular matrix organization. Neutrophil degranulation [52], innate immune system [53], platelet degranulation [54], extracellular matrix organization [55], diseases of glycosylation [56], platelet activation, signaling and aggregation [57], hemostasis [58], secretion [59], secretory vesicle [60], transmembrane transporter activity [61], cell adhesion [62], localization of cell [63], extracellular matrix [55], intrinsic component of plasma membrane [64], structural molecule activity [65], signaling receptor binding [66], have been highly noted in T2DM. Reports indicate that HIF1A [67], HLA-DRB1 [68], CHI3L1 [69], ADORA2A [70], ADRB2 [71], CLU (clusterin) [72], AGT (angiotensinogen) [73], VCAM1 [74], PPARA (peroxisome proliferator activated receptor alpha) [75], APOL1 [76], ZFP36 [77], PPM1B [78], SOCS1 [79], SNCA (synuclein alpha) [80], CTSS (cathepsin S) [81], IL6R [82], CFB (complement factor B) [83], DEFB1 [84], VNN1 [85], RAB27A [86], DPP4 [87], RARRES2 [88], CASP1 [89], LCN2 [90], REG3A [91], CD74 [92], PCSK2 [93], CHGB (chromogranin B) [94], TTR (transthyretin) [95], LRG1 [96], ALB (albumin) [97], DPP7 [98], 
APOH (apolipoprotein H) [99], CTSD (cathepsin D) [100], GCG (glucagon) [101], KCNQ1 [102], NR4A1 [103], PLIN5 [104], ALDH2 [105], ANG (angiogenin) [106], CLDN7 [107], PRLR (prolactin receptor) [108], SOD2 [109], MLXIPL (MLX interacting protein like) [110], CTSD (cathepsin D) [111], PECAM1 [112], ADA (adenosine deaminase) [113], MFGE8 [114], COL1A1 [115], COL3A1 [116], NID2 [117], ARG1 [118], CD93 [119], IGF2 [120], IL18 [121], LAMA1 [122], HPSE (heparanase) [123], BMP4 [124], CXCR4 [125], KDR (kinase insert domain receptor) [126], ESAM (endothelial cell adhesion molecule) [127], THBS1 [128], CD34 [129], SERPINE1 [130], WNT5B [131], MGP (matrix Gla protein) [132], MMP3 [133], MMP9 [134], MMP11 [135], IL16 [136], TNFRSF11B [137], TIMP3 [138] and CAPN3 [139] were found in T2DM. HLA-A [140], HLA-B [141], HLA-C [142], HLA-DPB1 [143], HLA-E [144], ERBB3 [145], MFAP4 [146] and JAK3 [147] have been reported significantly expressed in type 1 diabetes mellitus, but these genes might be involved in T2DM progression. HLADRA [148], SERPINA1 [149], ABHD12 [150], IMPA2 [151], ARSA (arylsulfatase A) [152], LRFN5 [153], PLXNA4 [154], CHL1 [155], ITPKB (inositol-trisphosphate 3-kinase B) [156], PTN (pleiotrophin) [157], LAMA2 [158], CDH6 [159] and A2M [160] have been shown to have an important role in neurological disorders, but these genes might be associated with progression of T2DM. HLA-F [161], HLA-H [162], FGA (fibrinogen alpha chain) [163], HSPA1B [164], MRC1 [165], DAB2IP [166], KCNJ8 [167], KLKB1 [168], CXCL2 [169], SERPINE2 [170], ADH1C [171], AMBP (alpha-1microglobulin/bikunin precursor) [172], NR4A2 [173], TYMP (thymidine phosphorylase) [174], TFRC (transferrin receptor) [175], PLAU (plasminogen activator, urokinase) [176], COL6A2 [177], COL15A1 [178], ABI3BP [179], NEXN (nexilin F-actin binding protein) [180], S1PR1 [181], THY1 [182], COL4A1 [183], COL5A2 [184], ADAMTS2 [185], ECM1 [186] and LTBP2 [187] have been found to be differentially expressed in cardiovascular diseases, but these genes might be linked with progression of T2DM. CCL20 [188], CRH (corticotropin releasing hormone) [189], SPP1 [190], LDLR (low density lipoprotein receptor) [191], RORA (RAR related orphan receptor A) [192], LYZ (lysozyme) [193], PTPRN2 [194], DAPK2 [195], OIP5 [196], PON3 [197], NR4A3 [198], VCAN (versican) [199], CNTNAP2 [200], IL1RAP [201], GLI2 [202], CDH13 [203], AEBP1 [204], BGN (biglycan) [205], LOX (lysyl oxidase) [206], IL1RL1 [207] and LUM (lumican) [208] were found to be involved in 
advancement of obesity, but these genes might be key for development of T2DM. C4BPA [209], KYNU (kynureninase) [210], ORM1 [211], ARSA (arylsulfatase A) [212], CYB5R3 [213], MAT1A [214], SDC4 [215], ASL (argininosuccinate lyase) [216], SLC4A4 [217], EPHB6 [218], SPARCL1 [219], THBS2 [220], EFNB2 [221] and CD248 [222] were revealed to be associated with hypertension, but these genes might be involved in progression of T2DM. GSDMD (gasdermin D) [223], UNC5B [224] and PDGFB (platelet derived growth factor subunit B) [225] have been reported significantly expressed in diabetic nephropathy.

A PPI network and modules was constructed and analyzed with DEGs, and then hub genes were identified. Gregg et al [226] revealed that CDK1 involvement in of obesity, but this gene might be associated with advancement of T2DM. ACTA2 was revealed to be associated with development of T2DM [227]. JUN (jun proto-oncogene, AP-1 transcription factor subunit), RELA (RELA proto-oncogene, NF-kB subunit), U2AF2, TK1, RAB5C, OCRL (OCRL inositol polyphosphate-5phosphatase), COL5A1, FN1, SPARC (secreted protein acidic and cysteine rich), TGFBI (transforming growth factor beta induced) and COL1A2 might be the novel biomarkers for the advancement of T2DM.

In this investigation, miRNA-hub gene regulatory network and TF-hub gene regulatory network were constructed and analyzed. Demirsoy et al [228], Hourigan et al [229], Safar et al [230], Zmuda et al [231], Boese et al [232] and Suhara et al [233] found that hsa-mir-200a-3p, hsa-mir-181c-5p, VDR (vitamin D receptor), ATF3, PAX6 and RPTOR (regulatory associated protein of MTOR complex 1) were participating in the occurrence and development of T2DM. Cabiati et al [234] and Patankar et al [235] proved that hsa-mir-410-3p and GATA4 mediate the development of obesity, but these genes might be associated with development of T2DM. Hsa-mir-3941 [236], BACH1 [237], GATA2 [238], FOXP1 [239] and HEY1 [240] were found to be involved in the process of cardiovascular diseases, but these genes might be associated with development of T2DM. Hsa-mir-708$5 p$ was revealed to be correlated with disease outcome in patients with neurological disorders [241], but this gene might be linked with development of T2DM. A previous study found that MRPL12 [242] and MME (membrane metalloendopeptidase) [243] expression could enhance the diabetic nephropathy. A previous study showed that CHEK1 gene is involved in the hypertension [244], but this gene might be associated in development of T2DM. Hsa-mir-1255b-5p, 
hsa-mir-499a-5p, hsa-mir-449c-5p, hsa-mir-520a-5p, hsa-mir-181d-3p, TFCP2L1, HOXC9, TBX3, KIT (KIT proto-oncogene, receptor tyrosine kinase), TOP2A, POLR2A and ANLN (anillin actin binding protein) might be the novel biomarkers for the advancement of T2DM.

In conclusion, the current investigation exhibits the global profile of DEGs and relative signaling pathways that might participate in the initiation and advancement of T2DM. In the pathogenesis of T2DM, the possible hub genes are JUN, VCAM1, RELA, U2AF2, ADRB2, FN1, CDK1, TK1, A2M and ACTA2. These results could help elucidate the molecular mechanism underlying T2DM pathogenesis and provide potential targets for T2DM therapy. Therefore, more experiments are required to ascertain the clinical value of the identified hub genes as biomarkers and the underlying molecular mechanism.

\section{Acknowledgement}

I thank Jonathan Schug, University of Pennsylvania, School of Medicine, NextGeneration Sequencing Core, Philadelphia, Pennsylvania, USA, very much, the author who deposited their profiling by high throughput sequencing dataset GSE154126, into the public GEO database.

\section{Conflict of interest}

The authors declare that they have no conflict of interest.

\section{Ethical approval}

This article does not contain any studies with human participants or animals performed by any of the authors.

\section{Informed consent}

No informed consent because this study does not contain human or animals participants.

\section{Availability of data and materials}

The datasets supporting the conclusions of this article are available in the GEO (Gene Expression Omnibus) (https://www.ncbi.nlm.nih.gov/geo/) repository. 
[(GSE154126)

(https://www.ncbi.nlm.nih.gov/geo/query/acc.cgi?acc=GSE154126)]

\section{Consent for publication}

Not applicable.

\section{Competing interests}

The authors declare that they have no competing interests.

\section{Author Contributions}

B. V. - Writing original draft, and review and editing

C. V. - Software and investigation

\section{Authors}

Basavaraj Vastrad

Chanabasayya Vastrad
ORCID ID: 0000-0003-2202-7637

ORCID ID: $\underline{0000-0003-3615-4450}$

\section{References}

1. Jing X, Chen J, Dong Y, Han D, Zhao H, Wang X, Gao F, Li C, Cui Z, Liu $\mathrm{Y}$, et al. Related factors of quality of life of type 2 diabetes patients: a systematic review and meta-analysis. Health Qual Life Outcomes. 2018;16(1):189. doi:10.1186/s12955-018-1021-9

2. Moran C, Beare R, Wang W, Callisaya M, Srikanth V; Alzheimer's Disease Neuroimaging Initiative (ADNI). Type 2 diabetes mellitus, brain atrophy, and cognitive decline. Neurology. 2019;92(8):e823-e830. doi:10.1212/WNL.0000000000006955

3. Cannon CP, Perkovic V, Agarwal R, Baldassarre J, Bakris G, Charytan DM, de Zeeuw D, Edwards R, Greene T, Heerspink HJL, et al Evaluating the Effects of Canagliflozin on Cardiovascular and Renal Events in Patients With Type 2 Diabetes Mellitus and Chronic Kidney Disease According to Baseline HbA1c, Including Those With HbA1c <7\%: Results From the CREDENCE Trial. Circulation. 2020;141(5):407-410. doi:10.1161/CIRCULATIONAHA.119.044359 
4. Choi EY, Park SE, Lee SC, Koh HJ, Kim SS, Byeon SH, Kim M. et al. Association Between Clinical Biomarkers and Optical Coherence Tomography Angiography Parameters in Type 2 Diabetes Mellitus. Invest Ophthalmol Vis Sci. 2020;61(3):4. doi:10.1167/iovs.61.3.4

5. Kenny HC, Abel ED. Heart Failure in Type 2 Diabetes Mellitus. Circ Res. 2019;124(1):121-141. doi:10.1161/CIRCRESAHA.118.311371

6. García-Chapa EG, Leal-Ugarte E, Peralta-Leal V, Durán-González J, MezaEspinoza JP. Genetic Epidemiology of Type 2 Diabetes in Mexican Mestizos. Biomed Res Int. 2017;2017:3937893. doi:10.1155/2017/3937893

7. Dendup T, Feng X, Clingan S, Astell-Burt T. Environmental Risk Factors for Developing Type 2 Diabetes Mellitus: A Systematic Review. Int J Environ Res Public Health. 2018;15(1):78. doi:10.3390/ijerph15010078

8. Sun Y, Gao HY, Fan ZY, He Y, Yan YX. Metabolomics Signatures in Type 2 Diabetes: A Systematic Review and Integrative Analysis. J Clin Endocrinol Metab. 2020;105(4):dgz240. doi:10.1210/clinem/dgz240

9. Kahn SE, Hull RL, Utzschneider KM. Mechanisms linking obesity to insulin resistance and type 2 diabetes. Nature. 2006;444(7121):840-846. doi:10.1038/nature05482

10.Climie RE, van Sloten TT, Bruno RM, Taddei S, Empana JP, Stehouwer CDA, Sharman JE, Boutouyrie P, Laurent S. Macrovasculature and Microvasculature at the Crossroads Between Type 2 Diabetes Mellitus and Hypertension. Hypertension. 2019;73(6):1138-1149. doi:10.1161/HYPERTENSIONAHA.118.11769

11.Mofo Mato EP, Guewo-Fokeng M, Essop MF, Owira PMO. Genetic polymorphisms of organic cation transporter 1 (OCT1) and responses to metformin therapy in individuals with type 2 diabetes: A systematic review. Medicine (Baltimore). 2018;97(27):e11349. doi:10.1097/MD.0000000000011349

12.Guo X, Li C, Wu J, Mei Q, Liu C, Sun W, Xu L, Fu S. The association of TNF- $\alpha-308 \mathrm{G} / \mathrm{A}$ and $-238 \mathrm{G} / \mathrm{A}$ polymorphisms with type 2 diabetes mellitus: a meta-analysis. Biosci Rep. 2019;39(12):BSR20191301. doi:10.1042/BSR20191301

13.Ding W, Xu L, Zhang L, Han Z, Jiang Q, Wang Z, Jin S. Meta-analysis of association between TCF7L2 polymorphism rs7903146 and type 2 diabetes mellitus. BMC Med Genet. 2018;19(1):38. doi:10.1186/s12881-018-0553-5 
14.Rizvi S, Raza ST, Mahdi F, Singh SP, Rajput M, Rahman Q. Genetic polymorphisms in KCNJ11 (E23K, rs5219) and SDF-1 $\beta$ (G801A, rs1801157) genes are associated with the risk of type 2 diabetes mellitus. $\mathrm{Br}$ J Biomed Sci. 2018;75(3):139-144. doi:10.1080/09674845.2018.1473939

15.Bregar D, Cilenšek I, Mankoč S, Reschner A, Petrovič D, Globočnik Petrovič M. The joint effect of the endothelin receptor B gene (EDNRB) polymorphism rs10507875 and nitric oxide synthase 3 gene (NOS3) polymorphism rs869109213 in Slovenian patients with type 2 diabetes mellitus and diabetic retinopathy. Bosn J Basic Med Sci. 2018;18(1):80-86. doi:10.17305/bjbms.2017.2244

16. Huang X, Liu G, Guo J, Su Z. The PI3K/AKT pathway in obesity and type 2 diabetes. Int J Biol Sci. 2018;14(11):1483-1496. doi:10.7150/ijbs.27173

17.Akbari M, Hassan-Zadeh V. IL-6 signalling pathways and the development of type 2 diabetes. Inflammopharmacology. 2018;26(3):685-698. doi:10.1007/s10787-018-0458-0

18.Jin T, Liu L. The Wnt signaling pathway effector TCF7L2 and type 2 diabetes mellitus. Mol Endocrinol. 2008;22(11):2383-2392. doi:10.1210/me.2008-0135

19.Karolina DS, Armugam A, Tavintharan S, et al. MicroRNA 144 impairs insulin signaling by inhibiting the expression of insulin receptor substrate 1 in type 2 diabetes mellitus. PLoS One. 2011;6(8):e22839. doi:10.1371/journal.pone.0022839

20.Zuo Y. The role of adiponectin gene mediated by NF- $\kappa$ B signaling pathway in the pathogenesis of type 2 diabetes. Eur Rev Med Pharmacol Sci. 2018;22(4):1106-1112. doi:10.26355/eurrev_201802_14398

21. Yang F, Chen Y, Xue Z, Lv Y, Shen L, Li K, Zheng P, Pan P, Feng T, Jin L, et al. High-Throughput Sequencing and Exploration of the IncRNAcircRNA-miRNA-mRNA Network in Type 2 Diabetes Mellitus. Biomed Res Int. 2020;2020:8162524. doi:10.1155/2020/8162524

22.Avrahami D, Wang YJ, Schug J, Feleke E, Gao L, Liu C; HPAP Consortium, Naji A, Glaser B, Kaestner KH. Single-cell transcriptomics of human islet ontogeny defines the molecular basis of $\beta$-cell dedifferentiation in T2D. Mol Metab. 2020;42:101057. doi:10.1016/j.molmet.2020.101057

23.Clough E, Barrett T. The Gene Expression Omnibus Database. Methods Mol Biol. 2016;1418:93-110. doi:10.1007/978-1-4939-3578-9_5 
24. Ritchie ME, Phipson B, Wu D, Hu Y, Law CW, Shi W, Smyth GK. limma powers differential expression analyses for RNA-sequencing and microarray studies. Nucleic Acids Res. 2015;43(7):e47. doi:10.1093/nar/gkv007

25. Thomas PD. The Gene Ontology and the Meaning of Biological Function.

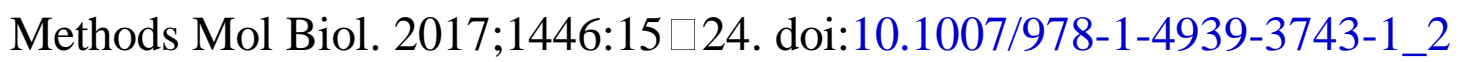

26.Fabregat A, Jupe S, Matthews L, Sidiropoulos K, Gillespie M, Garapati P, Haw R, Jassal B, Korninger F, May B et al The Reactome Pathway Knowledgebase. Nucleic Acids Res. 2018;46(D1):D649-D655. doi:10.1093/nar/gkx1132

27. Chen J, Bardes EE, Aronow BJ, Jegga AG. ToppGene Suite for gene list enrichment analysis and candidate gene prioritization. Nucleic Acids Res. 2009;37(Web Server issue):W305-W311. doi:10.1093/nar/gkp427

28. Orchard S, Ammari M, Aranda B, Breuza L, Briganti L, Broackes-Carter F, Campbell NH, Chavali G, Chen C, del-Toro N, et al. The MIntAct project-IntAct as a common curation platform for 11 molecular interaction databases. Nucleic Acids Res. 2014;42(Database issue):D358-D363. doi:10.1093/nar/gkt1115

29. Shannon P, Markiel A, Ozier O, Baliga NS, Wang JT, Ramage D, Amin N, Schwikowski B, Ideker T Cytoscape: a software environment for integrated models of biomolecular interaction networks. Genome Res 2003;13(11):2498-2504. doi:10.1101/gr.1239303

30.Przulj N, Wigle DA, Jurisica I. Functional topology in a network of protein interactions. Bioinformatics. 2004;20(3):340-348. doi:10.1093/bioinformatics/btg415

31.Nguyen TP, Liu WC, Jordán F. Inferring pleiotropy by network analysis: linked diseases in the human PPI network. BMC Syst Biol. 2011;5:179. doi:10.1186/1752-0509-5-179

32. Shi Z, Zhang B. Fast network centrality analysis using GPUs. BMC Bioinformatics. 2011;12:149. doi:10.1186/1471-2105-12-149

33.Fadhal E, Gamieldien J, Mwambene EC. Protein interaction networks as metric spaces: a novel perspective on distribution of hubs. BMC Syst Biol. 2014;8:6. doi:10.1186/1752-0509-8-6

34. Zaki N, Efimov D, Berengueres J. Protein complex detection using interaction reliability assessment and weighted clustering coefficient. BMC Bioinformatics. 2013;14:163. doi:10.1186/1471-2105-14 
35.Fan Y, Xia J (2018) miRNet-Functional Analysis and Visual Exploration of miRNA-Target Interactions in a Network Context. Methods Mol Biol 1819:215-233. doi:10.1007/978-1-4939-8618-7_10

36.Zhou G, Soufan O, Ewald J, Hancock REW, Basu N, Xia J (2019) NetworkAnalyst 3.0: a visual analytics platform for comprehensive gene expression profiling and meta-analysis. Nucleic Acids Res 47:W234-W241. doi:10.1093/nar/gkz240

37.Robin X, Turck N, Hainard A, Tiberti N, Lisacek F, Sanchez JC, Müller M. pROC: an open-source package for $\mathrm{R}$ and $\mathrm{S}+$ to analyze and compare ROC curves. BMC Bioinformatics 2011;12:77. doi:10.1186/1471-2105-12-77

38.Livak KJ, Schmittgen TD Analysis of relative gene expression data using real-time quantitative PCR and the 2(-Delta Delta C(T)) Method. Methods 2001;25:402-408. doi:10.1006/meth.2001.1262

39.Emmens JE, Ter Maaten JM, Damman K, van Veldhuisen DJ, de Boer RA, Struck J, Bergmann A, Sama IE, Streng KW, Anker SD, et al. Proenkephalin, an Opioid System Surrogate, as a Novel Comprehensive Renal Marker in Heart Failure. Circ Heart Fail. 2019;12(5):e005544. doi:10.1161/CIRCHEARTFAILURE.118.005544

40.Wang Y, Cao F, Wang Y, Yu G, Jia BL. Silencing of SAA1 inhibits palmitate- or high-fat diet induced insulin resistance through suppression of the NF-кB pathway. Mol Med. 2019;25(1):17. doi:10.1186/s10020-0190075-4

41.Du B, Jia X, Tian W, Yan X, Wang N, Cai D, Li X, Zhang H, Jin M, Wu N, et al. Associations of SUCNR1, GRK4, CAMK1D gene polymorphisms and the susceptibility of type 2 diabetes mellitus and essential hypertension in a northern Chinese Han population. J Diabetes Complications. 2021;35(1):107752. doi:10.1016/j.jdiacomp.2020.107752

42. Yeo ES, Hwang JY, Park JE, Choi YJ, Huh KB, Kim WY. Tumor necrosis factor (TNF-alpha) and C-reactive protein (CRP) are positively associated with the risk of chronic kidney disease in patients with type 2 diabetes. Yonsei Med J. 2010;51(4):519-525. doi:10.3349/ymj.2010.51.4.519

43. Scarale MG, Copetti M, Garofolo M, Fontana A, Salvemini L, De Cosmo S, Lamacchia O, Penno G, Trischitta V, Menzaghi C.The Synergic Association of hs-CRP and Serum Amyloid P Component in Predicting All-Cause 
Mortality in Patients With Type 2 Diabetes. Diabetes Care. 2020;43(5):1025-1032. doi:10.2337/dc19-2489

44.Rees SD, Britten AC, Bellary S, O'Hare JP, Kumar S, Barnett AH, Kelly MA. The promoter polymorphism $-232 \mathrm{C} / \mathrm{G}$ of the PCK1 gene is associated with type 2 diabetes in a UK-resident South Asian population. BMC Med Genet. 2009;10:83. doi:10.1186/1471-2350-10-83

45.Rodriguez S, Eiriksdottir G, Gaunt TR, Harris TB, Launer LJ, Gudnason V, Day IN. IGF2BP1, IGF2BP2 and IGF2BP3 genotype, haplotype and genetic model studies in metabolic syndrome traits and diabetes. Growth Horm IGF Res. 2010;20(4):310-318. doi:10.1016/j.ghir.2010.04.002

46.Luo Y, Qu H, Wang H, Wei H, Wu J, Duan Y, Liu D, Deng H. Plasma Periostin Levels Are Increased in Chinese Subjects with Obesity and Type 2 Diabetes and Are Positively Correlated with Glucose and Lipid Parameters. Mediators Inflamm. 2016;2016:6423637. doi:10.1155/2016/6423637

47.Dankel SN, Svärd J, Matthä S, Claussnitzer M, Klöting N, Glunk V, Fandalyuk Z, Grytten E, Solsvik MH, Nielsen HJ, et al. COL6A3 expression in adipocytes associates with insulin resistance and depends on PPAR $\gamma$ and adipocyte size. Obesity (Silver Spring). 2014;22(8):1807-1813. doi:10.1002/oby.20758

48.Lisa Y, Sook- HF, Yee- HS. Association of the Cocaine- and AmphetamineRegulated Transcript Prepropeptide Gene (CARTPT) rs2239670 Variant with Obesity among Kampar Health Clinic Patrons, Malaysia. Malays J Med Sci. 2012;19(1):43-51.

49.Nam JS, Ahn CW, Park HJ, Kim YS. Semaphorin $3 \square \mathrm{C}$ is a Novel Adipokine Representing Exercise-Induced Improvements of Metabolism in Metabolically Healthy Obese Young Males. Sci Rep. 2020;10(1):10005. doi:10.1038/s41598-020-67004-7

50.Poulain-Godefroy O, Eury E, Leloire A, Hennart B, Guillemin GJ, Allorge D, Froguel P.Induction of TDO2 and IDO2 in Liver by High-Fat Feeding in Mice: Discrepancies with Human Obesity. Int J Tryptophan Res. 2013;6(Suppl 1):29-37. doi:10.4137/IJTR.S11717

51.Sun CP, Sun D, Luan ZL, Dai X, Bie X, Ming WH, Sun XW, Huo XX, Lu TL, Zhang D. Association of SOX11 Polymorphisms in distal 3'UTR with Susceptibility for Schizophrenia. J Clin Lab Anal. 2020;34(8):e23306. doi:10.1002/jcla.23306 
52.Gorudko IV, Kostevich VA, Sokolov AV, Shamova EV, Buko IV, Konstantinova EE, Vasiliev VB, Cherenkevich SN, Panasenko OM. Functional activity of neutrophils in diabetes mellitus and coronary heart disease: role of myeloperoxidase in the development of oxidative stress. Bull Exp Biol Med. 2012;154(1):23-26. doi:10.1007/s10517-012-1865-7

53. Creely SJ, McTernan PG, Kusminski CM, Fisher fM, Da Silva NF, Khanolkar M, Evans M, Harte AL, Kumar S. Lipopolysaccharide activates an innate immune system response in human adipose tissue in obesity and type 2 diabetes. Am J Physiol Endocrinol Metab. 2007;292(3):E740-E747. doi:10.1152/ajpendo.00302.2006

54.Fateh-Moghadam S, Li Z, Ersel S, Reuter T, Htun P, Plöckinger U, Bocksch W, Dietz R, Gawaz M. Platelet degranulation is associated with progression of intima-media thickness of the common carotid artery in patients with diabetes mellitus type 2. Arterioscler Thromb Vasc Biol. 2005;25(6):12991303. doi:10.1161/01.ATV.0000165699.41301.c5

55.Liu JH, Chen Y, Zhen Z, Ho LM, Tsang A, Yuen M, Lam K, Tse HF, Yiu KH. Relationship of biomarkers of extracellular matrix with myocardial function in Type 2 diabetes mellitus. Biomark Med. 2017;11(7):569-578. doi:10.2217/bmm-2017-0044

56.Kundu D, Roy A, Mandal T, Bandyopadhyay U, Ghosh E, Ray D. Relation of microalbuminuria to glycosylated hemoglobin and duration of type 2 diabetes. Niger J Clin Pract. 2013;16(2):216-220. doi:10.4103/11193077.110159

57.Suslova TE, Sitozhevskii AV, Ogurkova ON, Kravchenko ES, Kologrivova IV, Anfinogenova Y, Karpov RS. Platelet hemostasis in patients with metabolic syndrome and type 2 diabetes mellitus: cGMP- and NO-dependent mechanisms in the insulin-mediated platelet aggregation. Front Physiol. 2015;5:501. doi:10.3389/fphys.2014.00501

58.Palella E, Cimino R, Pullano SA, Fiorillo AS, Gulletta E, Brunetti A, Foti DP, Greco M. Laboratory Parameters of Hemostasis, Adhesion Molecules, and Inflammation in Type 2 Diabetes Mellitus: Correlation with Glycemic Control. Int J Environ Res Public Health. 2020;17(1):300. doi:10.3390/ijerph17010300

59.Cortez-Navarrete M, Martínez-Abundis E, Pérez-Rubio KG, González-Ortiz M, Méndez-Del Villar M. Momordica charantia Administration Improves 
Insulin Secretion in Type 2 Diabetes Mellitus. J Med Food. 2018;21(7):672677. doi:10.1089/jmf.2017.0114

60.Xiao Y, Zheng L, Zou X, Wang J, Zhong J, Zhong T. Extracellular vesicles in type 2 diabetes mellitus: key roles in pathogenesis, complications, and therapy. J Extracell Vesicles. 2019;8(1):1625677. doi:10.1080/20013078.2019.1625677

61. Saha S. Association between the membrane transporter proteins and type 2 diabetes mellitus. Expert Rev Clin Pharmacol. 2020;13(3):287-297. doi:10.1080/17512433.2020.1729125

62.Hegazy GA, Awan Z, Hashem E, Al-Ama N, Abunaji AB. Levels of soluble cell adhesion molecules in type 2 diabetes mellitus patients with macrovascular complications. J Int Med Res. 2020;48(4):300060519893858. doi:10.1177/0300060519893858

63.Tang X, Hu X, Yang X, Fan Y, Li Y, Hu W, Liao Y, Zheng MC, Peng W, Gao L. Predicting diabetes mellitus genes via protein-protein interaction and protein subcellular localization information. BMC Genomics. 2016;17 Suppl 4(Suppl 4):433. doi:10.1186/s12864-016-2795-y

64. Weijers RN. Lipid composition of cell membranes and its relevance in type 2 diabetes mellitus. Curr Diabetes Rev. 2012;8(5):390-400. doi:10.2174/157339912802083531

65.Nicolle E, Souard F, Faure P, Boumendjel A. Flavonoids as promising lead compounds in type 2 diabetes mellitus: molecules of interest and structureactivity relationship. Curr Med Chem. 2011;18(17):2661-2672. doi:10.2174/092986711795933777

66. Alghamdi F, Guo M, Abdulkhalek S, Crawford N, Amith SR, Szewczuk MR. A novel insulin receptor-signaling platform and its link to insulin resistance and type 2 diabetes. Cell Signal. 2014;26(6):1355-1368. doi:10.1016/j.cellsig.2014.02.015

67.Huang Y, Jin L, Yu H, Jiang G, Tam CHT, Jiang S, Zheng C, Jiang F, Zhang $\mathrm{R}$, Zhang $\mathrm{H}$, et al. SNPs in PRKCA-HIF1A-GLUT1 are associated with diabetic kidney disease in a Chinese Han population with type 2 diabetes. Eur J Clin Invest. 2020;50(9):e13264. doi:10.1111/eci.13264

68.Al-Daghri NM, Al-Attas O, Alokail MS, Alkharfy KM, Draz HM, Agliardi C, Mohammed AK, Guerini FR, Clerici M. Vitamin D receptor gene polymorphisms and HLA DRB $1 * 04$ cosegregation in Saudi type 2 diabetes 
$\begin{array}{llll}\text { patients. } & \mathrm{J} & \text { Immunol. } & \text { 2012;188(3):1325-1332. }\end{array}$ doi:10.4049/jimmunol.1101954

69.Zhang S, Sousa A, Lin M, Iwano A, Jain R, Ma B, Lee CM, Park JW, Kamle S, Carlson R, et al. Role of Chitinase 3-Like 1 Protein in the Pathogenesis of Hepatic Insulin Resistance in Nonalcoholic Fatty Liver Disease. Cells. 2021;10(2):201. doi:10.3390/cells10020201

70. Yamamoto M, Guo DH, Hernandez CM, Stranahan AM. Endothelial Adora2a Activation Promotes Blood-Brain Barrier Breakdown and Cognitive Impairment in Mice with Diet-Induced Insulin Resistance. J Neurosci. 2019;39(21):4179-4192. doi:10.1523/JNEUROSCI.2506-18.2019

71.Connor A, Baumgartner RN, Kerber RA, O'Brien E, Rai SN, Wolff RK, Slattery ML, Giuliano AR, Risendal BC, Byers TE, et al. ADRB2 G-G haplotype associated with breast cancer risk among Hispanic and nonHispanic white women: interaction with type 2 diabetes and obesity. Cancer Causes Control. 2012;23(10):1653-1663. doi:10.1007/s10552-012-0043-6

72.Cai R, Han J, Sun J, Huang R, Tian S, Shen Y, Dong X, Xia W, Wang S. Plasma Clusterin and the CLU Gene rs11136000 Variant Are Associated with Mild Cognitive Impairment in Type 2 Diabetic Patients. Front Aging Neurosci. 2016;8:179. doi:10.3389/fnagi.2016.00179

73. Woods TC, Satou R, Miyata K, Katsurada A, Dugas CM, Klingenberg NC, Fonseca VA, Navar LG. Canagliflozin Prevents Intrarenal Angiotensinogen Augmentation and Mitigates Kidney Injury and Hypertension in Mouse Model of Type 2 Diabetes Mellitus. Am J Nephrol. 2019;49(4):331-342. doi:10.1159/000499597

74.Nakamura K, Yamagishi S, Adachi H, Matsui T, Kurita-Nakamura Y, Takeuchi M, Inoue H, Imaizumi T. Serum levels of soluble form of receptor for advanced glycation end products (sRAGE) are positively associated with circulating AGEs and soluble form of VCAM-1 in patients with type 2 diabetes. Microvasc Res. 2008;76(1):52-56. doi:10.1016/j.mvr.2007.09.004

75.Bajaj M, Suraamornkul S, Hardies LJ, Glass L, Musi N, DeFronzo RA. Effects of peroxisome proliferator-activated receptor (PPAR)-alpha and PPAR-gamma agonists on glucose and lipid metabolism in patients with type 2 diabetes mellitus. Diabetologia. 2007;50(8):1723-1731. doi:10.1007/s00125-007-0698-9 
76.Chan GC, Divers J, Russell GB, Langefeld CD, Wagenknecht LE, Hsu FC, $\mathrm{Xu}$ J, Smith SC, Palmer ND, Hicks PJ, et al. FGF23 Concentration and APOL1 Genotype Are Novel Predictors of Mortality in African Americans With Type 2 Diabetes. Diabetes Care. 2018;41(1):178-186. doi:10.2337/dc17-0820

77. Caracciolo V, Young J, Gonzales D, Ni Y, Flowers SJ, Summer R, Waldman SA, Kim JK, Jung DY, Noh HL, et al. Myeloid-specific deletion of Zfp36 protects against insulin resistance and fatty liver in diet-induced obese mice. Am J Physiol Endocrinol Metab. 2018;315(4):E676-E693. doi:10.1152/ajpendo.00224.2017

78.Wu YS, Li ZM, Chen YT, Dai SJ, Zhou XJ, Yang YX, Lou JS, Ji LT, Bao YT, Xuan L, et al. Berberine Improves Inflammatory Responses of Diabetes Mellitus in Zucker Diabetic Fatty Rats and Insulin-Resistant HepG2 Cells through the PPM1B Pathway. J Immunol Res. 2020;2020:2141508. doi: $10.1155 / 2020 / 2141508$

79. Opazo-Ríos L, Sanchez Matus Y, Rodrigues-Díez RR, Carpio D, Droguett A, Egido J, Gomez-Guerrero C, Mezzano S.Anti-inflammatory, antioxidant and renoprotective effects of SOCS1 mimetic peptide in the BTBR ob/ob mouse model of type 2 diabetes. BMJ Open Diabetes Res Care. 2020;8(1):e001242. doi:10.1136/bmjdrc-2020-001242

80.Hong CT, Chen KY, Wang W, Chiu JY, Wu D, Chao TY, Hu CJ, Chau KD, Bamodu OA. Insulin Resistance Promotes Parkinson's Disease through Aberrant Expression of $\alpha$-Synuclein, Mitochondrial Dysfunction, and Deregulation of the Polo-Like Kinase 2 Signaling. Cells. 2020;9(3):740. doi:10.3390/cells9030740

81. Wen W, Sun H, Yang Y, Jia Y, Fang F, Qin Y, Zhang M, Wei Y. Usefulness of Cathepsin S to Predict Risk for Obstructive Sleep Apnea among Patients with Type 2 Diabetes. Dis Markers. 2020;2020:8819134. doi:10.1155/2020/8819134

82.Wu X, Yu T, Ji N, Huang Y, Gao L, Shi W, Yan Y, Li H, Ma L, Wu K, et al. IL6R inhibits viability and apoptosis of pancreatic beta-cells in type 2 diabetes mellitus via regulation by miR-22 of the JAK/STAT signaling pathway. Diabetes Metab Syndr Obes. 2019;12:1645-1657. doi:10.2147/DMSO.S211700 
83.Wang J, Yang MM, Li YB, Liu GD, Teng Y, Liu XM. Association of CFH and CFB gene polymorphisms with retinopathy in type 2 diabetic patients. Mediators Inflamm. 2013;2013:748435. doi:10.1155/2013/748435

84.Soraia Aguiar de Melo Dias R, Carlos Mourão Pinho R, Almeida FR, Alfredo Farias Bandeira F, Celerino da Silva R, Crovella S, de Carvalho Farias Vajgel B, Cimões R. Evaluation of DEFB1 polymorphisms in individuals with chronic periodontitis and diabetes mellitus type 2 in a population of northeastern Brazil. Spec Care Dentist. 2018;38(4):227-233. doi:10.1111/scd.12296

85.van Diepen JA, Jansen PA, Ballak DB, Hijmans A, Rutjes FP, Tack CJ, Netea MG, Schalkwijk J, Stienstra R. Genetic and pharmacological inhibition of vanin-1 activity in animal models of type 2 diabetes. Sci Rep. 2016;6:21906. Published 2016 Mar 2. doi:10.1038/srep21906

86.Jiang S, Shen D, Jia WJ, Han X, Shen N, Tao W, Gao X, Xue B, Li CJ. GGPPS-mediated Rab27A geranylgeranylation regulates $\beta$ cell dysfunction during type 2 diabetes development by affecting insulin granule docked pool formation. J Pathol. 2016;238(1):109-119. doi:10.1002/path.4652

87.Lee SA, Kim YR, Yang EJ, Kwon EJ, Kim SH, Kang SH, Park DB, Oh BC, Kim J, Heo ST, et al. CD26/DPP4 levels in peripheral blood and T cells in patients with type 2 diabetes mellitus. J Clin Endocrinol Metab. 2013;98(6):2553-2561. doi:10.1210/jc.2012-4288

88.Zhao K, Ding W, Zhang Y, Ma K, Wang D, Hu C, Liu J, Zhang X. Variants in the RARRES2 gene are associated with serum chemerin and increase the risk of diabetic kidney disease in type 2 diabetes. Int J Biol Macromol. 2020;165(Pt A):1574-1580. doi:10.1016/j.ijbiomac.2020.10.030

89.Vincent JA, Mohr S. Inhibition of caspase-1/interleukin-1beta signaling prevents degeneration of retinal capillaries in diabetes and galactosemia. Diabetes. 2007;56(1):224-230. doi:10.2337/db06-0427

90.Wang W, Ye S, Qian L, Xing Y, Ren A, Chen C, Li S, Xu J, Liu Q, Dong L, et al. Elevated serum lipocalin 2 levels are associated with indexes of both glucose and bone metabolism in type 2 diabetes mellitus. Endokrynol Pol. 2018;69(3):276-282. doi:10.5603/EP.a2018.0030

91.Wu Y, Quan Y, Liu Y, Liu K, Li H, Jiang Z, Zhang T, Lei H, Radek KA, Li D, et al. Hyperglycaemia inhibits REG3A expression to exacerbate TLR3- 
mediated skin inflammation in diabetes. Nat Commun. 2016;7:13393. doi:10.1038/ncomms13393

92.Chan PC, Wu TN, Chen YC, Lu CH, Wabitsch M, Tian YF, Hsieh PS. Targetted inhibition of CD74 attenuates adipose COX-2-MIF-mediated M1 macrophage polarization and retards obesity-related adipose tissue inflammation and insulin resistance. Clin Sci (Lond). 2018;132(14):15811596. doi:10.1042/CS20180041

93. Chang TJ, Chiu YF, Sheu WH, Shih KC, Hwu CM, Quertermous T, Jou YS, Kuo SS, et al. Genetic polymorphisms of PCSK2 are associated with glucose homeostasis and progression to type 2 diabetes in a Chinese population. Sci Rep. 2015;5:14380. doi:10.1038/srep14380

94.Herold Z, Herold M, Rosta K, Doleschall M, Somogyi A. Lower serum chromogranin B level is associated with type 1 diabetes and with type 2 diabetes patients with intensive conservative insulin treatment. Diabetol Metab Syndr. 2020;12:61. doi:10.1186/s13098-020-00569-5

95.Kwanbunjan K, Panprathip P, Phosat C, Chumpathat N, Wechjakwen N, Puduang S, Auyyuenyong R, Henkel I, Schweigert FJ. Association of retinol binding protein 4 and transthyretin with triglyceride levels and insulin resistance in rural thais with high type 2 diabetes risk. BMC Endocr Disord. 2018;18(1):26. doi:10.1186/s12902-018-0254-2

96.Liu JJ, Pek SLT, Wang J, Liu S, Ang K, Shao YM, Tang JI, Gurung RL, Tavintharan S, Tang WE, et al. Association of Plasma Leucine-Rich $\alpha-2$ Glycoprotein 1, a Modulator of Transforming Growth Factor- $\beta$ Signaling Pathway, With Incident Heart Failure in Individuals With Type 2 Diabetes. Diabetes Care. 2021;44(2):571-577. doi:10.2337/dc20-2065

97.Hu F, Lou Y, Shi J, Cao L, Wang C, Ma J, Peng X, Xu S, Chen H, Zhao D et al. Baseline serum albumin and its dynamic change is associated with type 2 diabetes risk: A large cohort study in China. Diabetes Metab Res Rev. 2020;36(5):e3296. doi:10.1002/dmrr.3296

98. Makrilakis K. The Role of DPP-4 Inhibitors in the Treatment Algorithm of Type 2 Diabetes Mellitus: When to Select, What to Expect. Int J Environ Res Public Health. 2019;16(15):2720. doi:10.3390/ijerph16152720

99. Castro A, Lázaro I, Selva DM, Céspedes E, Girona J, NúriaPlana, Guardiola M, Cabré A, Simó R, Masana L. APOH is increased in the plasma and liver 
of type 2 diabetic patients with metabolic syndrome. Atherosclerosis. 2010;209(1):201-205. doi:10.1016/j.atherosclerosis.2009.09.072

100. Ding L, Houben T, Oligschlaeger Y, Bitorina AV, Verwer BJ, Tushuizen ME, Shiri-Sverdlov R. Plasma Cathepsin D Activity Rather Than Levels Correlates With Metabolic Parameters of Type 2 Diabetes in Male Individuals. Front Endocrinol (Lausanne). 2020;11:575070. doi:10.3389/fendo.2020.575070

101. Li L, Gao K, Zhao J, Feng T, Yin L, Wang J, Wang C, Li C, Wang Y, Wang Q, et al. Glucagon gene polymorphism modifies the effects of smoking and physical activity on risk of type 2 diabetes mellitus in Han Chinese. Gene. 2014;534(2):352-355. doi:10.1016/j.gene.2013.09.121

102. Travers ME, Mackay DJ, Dekker Nitert M, Morris AP, Lindgren CM, Berry A, Johnson PR, Hanley N, Groop LC, McCarthy MI, et al. Insights into the molecular mechanism for type 2 diabetes susceptibility at the KCNQ1 locus from temporal changes in imprinting status in human islets. Diabetes. 2013;62(3):987-992. doi:10.2337/db12-0819

103. Ming Y, Yin Y, Sun Z. Interaction of Nuclear Receptor Subfamily 4 Group A Member 1 (Nr4a1) and Liver Linase B1 (LKB1) Mitigates Type 2 Diabetes Mellitus by Activating Monophosphate-Activated Protein Kinase (AMPK)/Sirtuin 1 (SIRT1) Axis and Inhibiting Nuclear Factor-kappa B (NF- $\kappa$ B) Activation. Med Sci Monit. 2020;26:e920278.. doi:10.12659/MSM.920278

104. Gemmink A, Daemen S, Brouwers B, Huntjens PR, Schaart G, Moonen-Kornips E, Jörgensen J, Hoeks J, Schrauwen P, Hesselink MKC. Dissociation of intramyocellular lipid storage and insulin resistance in trained athletes and type 2 diabetes patients; involvement of perilipin 5?. J Physiol. 2018;596(5):857-868. doi:10.1113/JP275182

105. Li GY, Li ZB, Li F, Dong LP, Tang L, Xiang J, Li JM, Bao MH. Meta-Analysis on the Association of ALDH2 Polymorphisms and Type 2 Diabetic Mellitus, Diabetic Retinopathy. Int J Environ Res Public Health. 2017;14(2):165. doi:10.3390/ijerph14020165

106. Siebert J, Reiwer-Gostomska M, Mysliwska J, Marek N, Raczynska $\mathrm{K}$, Glasner L. Glycemic control influences serum angiogenin concentrations in patients with type 2 diabetes. Diabetes Care. 2010;33(8):1829-1830. doi:10.2337/dc10-0130 
107. Belalcazar LM, Papandonatos GD, McCaffery JM, Peter I, Pajewski NM, Erar B, Allred ND, Balasubramanyam A, Bowden DW, Brautbar A, et al. A common variant in the CLDN7/ELP5 locus predicts adiponectin change with lifestyle intervention and improved fitness in obese individuals with diabetes. Physiol Genomics. 2015;47(6):215-224. doi:10.1152/physiolgenomics.00109.2014

108. Erdenebaatar C, Yamaguchi M, Monsur M, Saito F, Honda R, Tashiro H, Ohba T, Iyama KI, Katabuchi H. Serum Prolactin Contributes to Enhancing Prolactin Receptor and pJAK2 in Type I Endometrial Cancer Cells in Young Women Without Insulin Resistance. Int J Gynecol Pathol. 2019;38(4):318-325. doi:10.1097/PGP.0000000000000527

109. Işikli A, Kubat-Üzüm A, Satman İ, Matur Z, Öge AE, Küçükali Cİ, Tüzün E, Erden S, Özkök E. A SOD2 Polymorphism is Associated with Abnormal Quantitative Sensory Testing in Type 2 Diabetic Patients. Noro Psikiyatr Ars. 2018;55(3):276-279. doi:10.29399/npa.23027

110. Mtiraoui N, Turki A, Nemr R, Echtay A, Izzidi I, Al-Zaben GS, IraniHakime N, Keleshian SH, Mahjoub T, Almawi WY. Contribution of common variants of ENPP1, IGF2BP2, KCNJ11, MLXIPL, PPAR $\gamma$, SLC30A8 and TCF7L2 to the risk of type 2 diabetes in Lebanese and Tunisian Arabs. Diabetes Metab. 2012;38(5):444-449. doi:10.1016/j.diabet.2012.05.002

111. Ding L, Houben $\mathrm{T}$, Oligschlaeger $\mathrm{Y}$, Bitorina AV, Verwer BJ, Tushuizen ME, Shiri-Sverdlov R. Plasma Cathepsin D. Plasma Cathepsin D Activity Rather Than Levels Correlates With Metabolic Parameters of Type 2 Diabetes in Male Individuals. Front Endocrinol (Lausanne). 2020;11:575070. doi:10.3389/fendo.2020.575070

112. Završnik M, Kariž S, Makuc J, Šeruga M, Cilenšek I, Petrovič D. PECAM-1 Leu125Val (rs688) Polymorphism and Diabetic Nephropathy in Caucasians with Type 2 Diabetes Mellitus. Anal Cell Pathol (Amst). 2016;2016:3152967. doi:10.1155/2016/3152967

113. Niraula A, Thapa S, Kunwar S, Lamsal M, Baral N, Maskey R. Adenosine deaminase activity in type 2 diabetes mellitus: does it have any role?. BMC Endocr Disord. 2018;18(1):58. doi:10.1186/s12902-018-0284-9 114. Sun G, Liu J, Xia G, Zhang L, Li Y, Zhou Z, Lv Y, Wei S, Liu J, Quan J. Reduced serum milk fat globule-epidermal growth factor 8 (MFG- 
E8) concentrations are associated with an increased risk of microvascular complications in patients with type 2 diabetes. Clin Chim Acta. 2017;466:201-206. doi:10.1016/j.cca.2017.01.013

115. Lin G, Wan X, Liu D, Wen Y, Yang C, Zhao C. COL1A1 as a potential new biomarker and therapeutic target for type 2 diabetes. Pharmacol Res. 2021;105436. doi:10.1016/j.phrs.2021.105436

116. Gaikwad AB, Gupta J, Tikoo K. Epigenetic changes and alteration of Fbn1 and Col3A1 gene expression under hyperglycaemic and hyperinsulinaemic conditions. Biochem J. 2010;432(2):333-341. doi:10.1042/BJ20100414

117. Sasso FC, Marfella R, Pagano A, Porta G, Signoriello G, Lascar N, Minutolo R, Carbonara O, Persico M, Piscione F, et al. Lack of effect of aspirin in primary $\mathrm{CV}$ prevention in type 2 diabetic patients with nephropathy: results from 8 years follow-up of NID-2 study. Acta Diabetol. 2015;52(2):239-247. doi:10.1007/s00592-014-0623-X

118. Fawad Ali Shah S, Iqbal T, Naveed N, Akram S, Arshad Rafiq M, Hussain S. ARG1 single nucleotide polymorphisms rs2781666 and rs2781665 confer risk of Type 2 diabetes mellitus. EXCLI J. 2018;17:847855. doi:10.17179/excli2018-1178

119. Lee M, Park HS, Choi MY, Kim HZ, Moon SJ, Ha JY, Choi A, Park YW, Park JS, Shin EC, et al. Significance of Soluble CD93 in Type 2 Diabetes as a Biomarker for Diabetic Nephropathy: Integrated Results from Human and Rodent Studies. J Clin Med. 2020;9(5):1394. doi: $10.3390 / \mathrm{jcm} 9051394$

120. Mercader JM, Liao RG, Bell AD, Dymek Z, Estrada K, Tukiainen T, Huerta-Chagoya A, Moreno-Macías H, Jablonski KA, Hanson RL, et al. A Loss-of-Function Splice Acceptor Variant in IGF2 Is Protective for Type 2 Diabetes. Diabetes. 2017;66(11):2903-2914. doi:10.2337/db17-018

121. Hivert MF, Sun Q, Shrader P, Mantzoros CS, Meigs JB, Hu FB. Circulating IL-18 and the risk of type 2 diabetes in women. Diabetologia. 2009;52(10):2101-2108. doi:10.1007/s00125-009-1455-z

122. Perry JR, Voight BF, Yengo L, Amin N, Dupuis J, Ganser M, Grallert H, Navarro P, Li M, Qi L, et al. Yengo L, et al. Stratifying type 2 diabetes cases by BMI identifies genetic risk variants in LAMA1 and enrichment for 
risk variants in lean compared to obese cases. PLoS Genet. 2012;8(5):e1002741. doi:10.1371/journal.pgen.1002741

123. Simeonovic CJ, Ziolkowski AF, Wu Z, Choong FJ, Freeman C, Parish CR. Heparanase and autoimmune diabetes. Front Immunol. 2013;4:471. doi:10.3389/fimmu.2013.00471

124. Youn JY, Zhou J, Cai H. Bone Morphogenic Protein 4 Mediates NOX1-Dependent eNOS Uncoupling, Endothelial Dysfunction, and COX2 Induction in Type 2 Diabetes Mellitus. Mol Endocrinol. 2015;29(8):11231133. doi:10.1210/ME.2014-1313

125. Vidaković M, Grdović N, Dinić S, Mihailović M, Uskoković A, Arambašić Jovanović J. The Importance of the CXCL12/CXCR4 Axis in Therapeutic Approaches to Diabetes Mellitus Attenuation. Front Immunol. 2015;6:403. doi:10.3389/fimmu.2015.00403

126. Merlo S, Starčević JN, Mankoč S, Šantl Letonja M, Cokan Vujkovac A, Zorc M, Petrovič D. Vascular Endothelial Growth Factor Gene Polymorphism (rs2010963) and and Its Receptor, Kinase Insert DomainContaining Receptor Gene Polymorphism (rs2071559), and Markers of Carotid Atherosclerosis in Patients with Type 2 Diabetes Mellitus. J Diabetes Res. 2016;2016:1482194. doi:10.1155/2016/1482194

127. Kacso IM, Potra AR, Rusu A, Moldovan D, Rusu CC, Kacso G, Hancu ND, Muresan A, Bondor CI. su A, et al. Relationship of endothelial cell selective adhesion molecule to markers of oxidative stress in type 2 diabetes. Scand J Clin Lab Invest. 2014;74(2):170-176. doi:10.3109/00365513.2013.869700

128. Bai J, Xia M, Xue Y, Ma F, Cui A, Sun Y, Han Y, Xu X, Zhang F, Hu $\mathrm{Z}$, et al. Thrombospondin 1 improves hepatic steatosis in diet-induced insulin-resistant mice and is associated with hepatic fat content in humans. EBioMedicine. 2020;57:102849. doi:10.1016/j.ebiom.2020.102849

129. Yamashita A, Nishihira K, Matsuura Y, Ito T, Kawahara K, Hatakeyama K, Hashiguchi T, Maruyama I, Yagi H, Matsumoto M, et al. Paucity of CD34-positive cells and increased expression of high-mobility group box 1 in coronary thrombus with type 2 diabetes mellitus. Atherosclerosis. 2012;224(2):511-514. doi:10.1016/j.atherosclerosis.2012.07.027 
130. Fan Q, Li H, Qin Y, Li L, Chen L, Zhang L, Lv Y, Liang D, Liang Y, Long T, et al. Association of SERPINE1 rs6092 with type 2 diabetes and related metabolic traits in a Chinese population. Gene. 2018;661:176-181. doi:10.1016/j.gene.2018.04.011

131. Salpea KD, Gable DR, Cooper JA, Stephens JW, Hurel SJ, Ireland HA, Feher MD, Godsland IF, Humphries SE. The effect of WNT5B IVS3C $>\mathrm{G}$ on the susceptibility to type 2 diabetes in UK Caucasian subjects. Nutr Metab Cardiovasc Dis. 2009;19(2):140-145. doi:10.1016/j.numecd.2008.02.009

132. Sardana M, Vasim I, Varakantam S, Kewan U, Tariq A, Koppula MR, Syed AA, Beraun M, Drummen NE, Vermeer C, et al. Inactive Matrix GlaProtein and Arterial Stiffness in Type 2 Diabetes Mellitus. Am J Hypertens. 2017;30(2):196-201. doi:10.1093/ajh/hpw146

133. Lee JE, Choi YK, Seo HA, Jeon JH, Jeong JY, Moon SS, Kim JG, Kim BW, Kim SW, Min Yoo, et al. Impact of ENPP1 and MMP3 gene polymorphisms on aortic calcification in patients with type 2 diabetes in a Korean population. Diabetes Res Clin Pract. 2010;88(1):87-96. doi:10.1016/j.diabres.2010.01.002

134. Kaminari A, Tsilibary EC, Tzinia A. A New Perspective in Utilizing MMP-9 as a Therapeutic Target for Alzheimer's Disease and Type 2 Diabetes Mellitus. J Alzheimers Dis. 2018;64(1):1-16. doi:10.3233/JAD180035

135. Arcidiacono B, Chiefari E, Laria AE, Messineo S, Bilotta FL, Britti D, Foti DP, Foryst-Ludwig A, Kintscher U, Brunetti A. Expression of matrix metalloproteinase-11 is increased under conditions of insulin resistance. World J Diabetes. 2017;8(9):422-428. doi:10.4239/wjd.v8.i9.422

136. Cheng F, Liu L, Zhang H, Zhu Y, Li X, Li H. Association of IL-16 gene polymorphisms with the risk of developing type 2 diabetes mellitus in the Chinese Han population. Biosci Rep. 2019;39(8):BSR20190821. doi:10.1042/BSR20190821

137. Biscetti F, Porreca CF, Bertucci F, Straface G, Santoliquido A, Tondi P, Angelini F, Pitocco D, Santoro L, Gasbarrini A, et al. TNFRSF11B gene polymorphisms increased risk of peripheral arterial occlusive disease and critical limb ischemia in patients with type 2 diabetes. Acta Diabetol. 2014;51(6):1025-1032. doi:10.1007/s00592-014-0664-1 
138. Jiang C, Xia W, Wu T, Pan C, Shan H, Wang F, Zhou Z, Yu X. Inhibition of microRNA-222 up-regulates TIMP3 to promotes osteogenic differentiation of MSCs from fracture rats with type 2 diabetes mellitus. J Cell Mol Med. 2020;24(1):686-694. doi:10.1111/jcmm.14777

139. Walder K, McMillan J, Lapsys N, Kriketos A, Trevaskis J, Civitarese A, Southon A, Zimmet P, Collier G. Calpain 3 gene expression in skeletal muscle is associated with body fat content and measures of insulin resistance. Int J Obes Relat Metab Disord. 2002;26(4):442-449. doi:10.1038/sj.ijo.0801946

140. Howson JM, Walker NM, Clayton D, Todd JA; Type 1 Diabetes Genetics Consortium. Confirmation of HLA class II independent type 1 diabetes associations in the major histocompatibility complex including HLA-B and HLA-A. Diabetes Obes Metab. 2009;11 Suppl 1(Suppl 1):3145. doi:10.1111/j.1463-1326.2008.01001.x

141. Schloss J, Ali R, Racine JJ, Chapman HD, Serreze DV, DiLorenzo TP. HLA-B*39:06 Efficiently Mediates Type 1 Diabetes in a Mouse Model Incorporating Reduced Thymic Insulin Expression. J Immunol. 2018;200(10):3353-3363. doi:10.4049/jimmunol.1701652

142. Zhi D, Sun C, Sedimbi SK, Luo F, Shen S, Sanjeevi CB. Killer cell immunoglobulin-like receptor along with HLA-C ligand genes are associated with type 1 diabetes in Chinese Han population. Diabetes Metab Res Rev. 2011;27(8):872-877. doi:10.1002/dmrr.1264

143. Varney MD, Valdes AM, Carlson JA, Noble JA, Tait BD, Bonella P, Lavant E, Fear AL, Louey A, Moonsamy P, et al. HLA DPA1, DPB1 alleles and haplotypes contribute to the risk associated with type 1 diabetes: analysis of the type 1 diabetes genetics consortium families. Diabetes. 2010;59(8):2055-2062. doi:10.2337/db09-0680

144. Jiang H, Canfield SM, Gallagher MP, Jiang HH, Jiang Y, Zheng Z, Chess L. HLA-E-restricted regulatory CD8(+) $\mathrm{T}$ cells are involved in development and control of human autoimmune type 1 diabetes. J Clin Invest. 2010;120(10):3641-3650. doi:10.1172/JCI4352

145. Wang D, Pan G. The Association between rs2292239 Polymorphism in ERBB3 Gene and Type 1 Diabetes: A Meta-Analysis. Biomed Res Int. 2019;2019:7689642. doi:10.1155/2019/7689642 
146. Blindbæk SL, Schlosser A, Green A, Holmskov U, Sorensen GL, Grauslund J. Association between microfibrillar-associated protein 4 (MFAP4) and micro- and macrovascular complications in long-term type 1 diabetes mellitus. Acta Diabetol. 2017;54(4):367-372. doi:10.1007/s00592016-0953-y

147. Cetkovic-Cvrlje M, Dragt AL, Vassilev A, Liu XP, Uckun FM. Targeting JAK3 with JANEX-1 for prevention of autoimmune type 1 diabetes in NOD mice. Clin Immunol. 2003;106(3):213-225. doi:10.1016/s1521-6616(02)00049-9

148. Li J, Jian L, Huang J, Xiong N, Wang T. The rs3129882/rs4248166 in HLA-DRA and rs34372695 in SYT11 are not associated with sporadic Parkinson's disease in Central Chinese population. Int J Neurosci. 2020;1-7. doi:10.1080/00207454.2020.1753728

149. Halbgebauer S, Nagl M, Klafki H, Haußmann U, Steinacker P, Oeckl P, Kassubek J, Pinkhardt E, Ludolph AC, Soininen H, et al. Modified serpinA1 as risk marker for Parkinson's disease dementia: Analysis of baseline data. Sci Rep. 2016;6:26145. doi:10.1038/srep26145

150. Ichu TA, Reed A, Ogasawara D, Ulanovskaya O, Roberts A, Aguirre CA, Bar-Peled L, Gao J, Germain J, Barbas S, et al. ABHD12 and LPCAT3 Interplay Regulates a Lyso-phosphatidylserine-C20:4 Phosphatidylserine Lipid Network Implicated in Neurological Disease. Biochemistry. 2020;59(19):1793-1799. doi:10.1021/acs.biochem.0c00292

151. Bloch PJ, Weller AE, Doyle GA, Ferraro TN, Berrettini WH, Hodge $\mathrm{R}$, Lohoff FW. Association analysis between polymorphisms in the myoinositol monophosphatase 2 (IMPA2) gene and bipolar disorder. Prog Neuropsychopharmacol Biol Psychiatry. 2010;34(8):1515-1519. doi:10.1016/j.pnpbp.2010.08.015

152. Yoo HS, Lee JS, Chung SJ, Ye BS, Sohn YH, Lee SJ, Lee PH. Changes in plasma arylsulfatase A level as a compensatory biomarker of early Parkinson's disease. Sci Rep. 2020;10(1):5567. doi:10.1038/s41598020-62536-4

153. Cappuccio G, Attanasio S, Alagia M, Mutarelli M, Borzone R, Karali M, Genesio R, Mormile A, Nitsch L, Imperati F, et al. Microdeletion of pseudogene chr14.232.a affects LRFN5 expression in cells of a patient with 
autism spectrum disorder. Eur J Hum Genet. 2019;27(9):1475-1480. doi:10.1038/s41431-019-0430-5

154. Han Q, Sun YA, Zong Y, Chen C, Wang HF, Tan L. Common Variants in PLXNA4 and Correlation to CSF-related Phenotypes in Alzheimer's Disease. Front Neurosci. 2018;12:946. doi:10.3389/fnins.2018.00946

155. Yang CR, Ning L, Zhou FH, Sun Q, Meng HP, Han Z, Liu Y, Huang W, Liu S, Li XH, et al. Downregulation of Adhesion Molecule CHL1 in B Cells but Not T Cells of Patients with Major Depression and in the Brain of Mice with Chronic Stress. Neurotox Res. 2020;38(4):914-928. doi:10.1007/s12640-020-00234-9

156. Stygelbout V, Leroy K, Pouillon V, Ando K, D'Amico E, Jia Y, Luo HR, Duyckaerts C, Erneux C, Schurmans S, et al. on V, et al. Inositol trisphosphate 3-kinase $\mathrm{B}$ is increased in human Alzheimer brain and exacerbates mouse Alzheimer pathology. Brain. 2014;137(Pt 2):537-552. doi:10.1093/brain/awt344

157. Alguacil LF, Herradón G. Midkine and Pleiotrophin in the Treatment of Neurodegenerative Diseases and Drug Addiction. Recent Pat CNS Drug Discov. 2015;10(1):28-33. doi:10.2174/1574889810666150326103916

158. Ahmad S, Milan MDC, Hansson O, Demirkan A, Agustin R, Sáez ME, Giagtzoglou N, Cabrera-Socorro A, Bakker MHM, Ramirez A, et al. CDH6 and HAGH protein levels in plasma associate with Alzheimer's disease in APOE $\varepsilon 4$ carriers. Sci Rep. 2020;10(1):8233. doi:10.1038/s41598-020-65038-5

159. Arreguin AJ, Colognato H. Brain Dysfunction in LAMA2-Related Congenital Muscular Dystrophy: Lessons From Human Case Reports and Mouse Models. Front Mol Neurosci. 2020;13:118. doi:10.3389/fnmol.2020.00118

160. Bruno E, Quattrocchi G, Nicoletti A, Le Pira F, Maci T, Mostile G, Andreoli V, Quattrone A, Zappia M. Lack of interaction between LRP1 and A2M polymorphisms for the risk of Alzheimer disease. Neurosci Lett. 2010;482(2):112-116. doi:10.1016/j.neulet.2010.07.012

161. Zidi I, Kharrat N, Abdelhedi R, Hassine AB, Laaribi AB, Yahia HB, Abdelmoula NB, Abid L, Rebai A, Rizzo R. Nonclassical human leukocyte 
antigen (HLA-G, HLA-E, and HLA-F) in coronary artery disease. Hum Immunol. 2016;77(4):325-329. doi:10.1016/j.humimm.2016.01.008

162. Annichino-Bizzacchi JM, Saad ST, Arruda VR, Ramires JA, Siqueira

LH, Chiaparini LC, Mansur AP. C282Y mutation in the HLA-H gene is not a risk factor for patients with myocardial infarction. J Cardiovasc Risk. 2000;7(1):37-40. doi:10.1177/204748730000700107

163. Jacquemin B, Antoniades C, Nyberg F, Plana E, Müller M, Greven S,

Salomaa V, Sunyer J, Bellander T, Chalamandaris AG, et al. Common genetic polymorphisms and haplotypes of fibrinogen alpha, beta, and gamma chains affect fibrinogen levels and the response to proinflammatory stimulation in myocardial infarction survivors: the AIRGENE study. J Am Coll Cardiol. 2008;52(11):941-952. doi:10.1016/j.jacc.2008.06.016

164. Yang Z, Zhang Q, Yu H, Du H, Li L, He Y, Zhu S, Li C, Zhang S,

Luo B, et al. Genetic association study of a novel indel polymorphism in HSPA1B with the risk of sudden cardiac death in the Chinese populations.

Forensic Sci Int. 2021;318:110637. doi:10.1016/j.forsciint.2020.110637

165. Yarnazari A, Hassanpour P, Hosseini-Fard SR, Amirfarhangi A, Najafi M. The sdLDL Reduces MRC1 Expression Level and Secretion of Histamin e in Differentiated M2-macrophages from Patients with Coronary Artery Stenosis. Cardiovasc Hematol Disord Drug Targets. 2017;17(1):2832. doi:10.2174/1871529X17666170106095554

166. Harrison SC, Cooper JA, Li K, Talmud PJ, Sofat R, Stephens JW, Hamsten A; HIFMECH Consortium, Sanders J, Montgomery H, Neil A; Simon Broome Research Consortium, Humphries SE. Association of a sequence variant in DAB2IP with coronary heart disease. Eur Heart J. 2012;33(7):881-888. doi:10.1093/eurheartj/ehr075

167. Delaney JT, Muhammad R, Blair MA, Kor K, Fish FA, Roden DM, Darbar D. A KCNJ8 mutation associated with early repolarization and atrial fibrillation. $\quad$ Europace. 2012;14(10):1428-1432. doi:10.1093/europace/eus150

168. Gittleman HR, Merkulova A, Alhalabi O, Stavrou EX, Veigl ML, Barnholtz-Sloan JS, Schmaier AH. A Cross-sectional Study of KLKB1 and PRCP Polymorphisms in Patient Samples with Cardiovascular Disease. Front Med (Lausanne). 2016;3:17. doi:10.3389/fmed.2016.00017 
169. Guo LY, Yang F, Peng LJ, Li YB, Wang AP. CXCL2, a new critical factor and therapeutic target for cardiovascular diseases. Clin Exp Hypertens. 2020;42(5):428-437. doi:10.1080/10641963.2019.1693585

170. Li X, Zhao D, Guo Z, Li T, Qili M, Xu B, Qian M, Liang H, E X, Chege Gitau S, Wang L, et al. Overexpression of SerpinE2/protease nexin-1 Contribute to Pathological Cardiac Fibrosis via increasing Collagen Deposition. Sci Rep. 2016;6:37635. doi:10.1038/srep37635

171. Latella MC, Di Castelnuovo A, de Lorgeril M, Arnout J, Cappuccio FP, Krogh V, Siani A, van Dongen M, Donati MB, de Gaetano G, et al. Genetic variation of alcohol dehydrogenase type 1C (ADH1C), alcohol consumption, and metabolic cardiovascular risk factors: results from the IMMIDIET study. Atherosclerosis. 2009;207(1):284-290. doi:10.1016/j.atherosclerosis.2009.04.022

172. Liu H, Luo D, Qiu Y, Huang Y, Chen C, Song X, Gao L, Zhou Y. The Effect of AMBP SNPs, Their Haplotypes, and Gene-Environment Interactions on the Risk of Atherothrombotic Stroke Among the Chinese Population. Genet Test Mol Biomarkers. 2019;23(7):487-494. doi:10.1089/gtmb.2018.0248

173. Kardys I, van Tiel CM, de Vries CJ, Pannekoek H, Uitterlinden AG, Hofman A, Witteman JC, de Maat MP. Haplotypes of the NR4A2/NURR1 gene and cardiovascular disease: the Rotterdam Study. Hum Mutat. 2009;30(3):417-423. doi:10.1002/humu.20902

174. Li W, Yue H. Thymidine phosphorylase: A potential new target for treating cardiovascular disease. Trends Cardiovasc Med. 2018;28(3):157171. doi:10.1016/j.tcm.2017.10.003

175. Xu W, Barrientos T, Mao L, Rockman HA, Sauve AA, Andrews NC. Lethal Cardiomyopathy in Mice Lacking Transferrin Receptor in the Heart. Cell Rep. 2015;13(3):533-545. doi:10.1016/j.celrep.2015.09.023

176. Persson M, Engström G, Björkbacka H, Hedblad B. Soluble urokinase plasminogen activator receptor in plasma is associated with incidence of CVD. Results from the Malmö Diet and Cancer Study. Atherosclerosis. 2012;220(2):502-505. doi:10.1016/j.atherosclerosis.2011.10.039

177. Grossman TR, Gamliel A, Wessells RJ, Taghli-Lamallem O, Jepsen K, Ocorr K, Korenberg JR, Peterson KL, Rosenfeld MG, Bodmer R, et al. Over-expression of DSCAM and COL6A2 cooperatively generates 
congenital heart defects. PLoS Genet. 2011;7(11):e1002344. doi:10.1371/journal.pgen.1002344

178. Connelly JJ, Cherepanova OA, Doss JF, Karaoli T, Lillard TS, Markunas CA, Nelson S, Wang T, Ellis PD, Langford CF, et al. Epigenetic regulation of COL15A1 in smooth muscle cell replicative aging and atherosclerosis. Hum Mol Genet. 2013;22(25):5107-5120. doi:10.1093/hmg/ddt365

179. Delfín DA, DeAguero JL, McKown EN. The Extracellular Matrix Protein ABI3BP in Cardiovascular Health and Disease. Front Cardiovasc Med. 2019;6:23. doi:10.3389/fcvm.2019.00023

180. Hu YW, Guo FX, Xu YJ, Li P, Lu ZF, McVey DG, Zheng L, Wang $\mathrm{Q}$, Ye JH, Kang CM, et al. Long noncoding RNA NEXN-AS1 mitigates atherosclerosis by regulating the actin-binding protein NEXN. J Clin Invest. 2019;129(3):1115-1128. doi:10.1172/JCI98230

181. Deng S, Zhou X, Ge Z, Song Y, Wang H, Liu X, Zhang D. Exosomes from adipose-derived mesenchymal stem cells ameliorate cardiac damage after myocardial infarction by activating S1P/SK1/S1PR1 signaling and promoting macrophage M2 polarization. Int $\mathrm{J}$ Biochem Cell Biol. 2019;114:105564. doi:10.1016/j.biocel.2019.105564

182. Li Y, Song D, Mao L, Abraham DM, Bursac N. Lack of Thy1 defines a pathogenic fraction of cardiac fibroblasts in heart failure. Biomaterials. 2020;236:119824. doi:10.1016/j.biomaterials.2020.119824

183. Raza ST, Abbas S, Eba A, Karim F, Wani IA, Rizvi S, Zaidi A, Mahdi F. Association of COL4A1 (rs605143, rs565470) and CD14 (rs2569190) genes polymorphism with coronary artery disease. Mol Cell Biochem. 2018;445(1-2):117-122. doi:10.1007/s11010-017-3257-9

184. Azuaje F, Zhang L, Jeanty C, Puhl SL, Rodius S, Wagner DR. Analysis of a gene co-expression network establishes robust association between Col5a2 and ischemic heart disease. BMC Med Genomics. 2013;6:13. doi:10.1186/1755-8794-6-13

185. Wang X, Chen W, Zhang J, Khan A, Li L, Huang F, Qiu Z, Wang L, Chen X. Critical Role of ADAMTS2 (A Disintegrin and Metalloproteinase With Thrombospondin Motifs 2) in Cardiac Hypertrophy Induced by Pressure Overload. Hypertension. 2017;69(6):1060-1069. doi:10.1161/HYPERTENSIONAHA.116.08581 
186. Hardy SA, Mabotuwana NS, Murtha LA, Coulter B, SanchezBezanilla S, Al-Omary MS, Senanayake T, Loering S, Starkey M, Lee RJ, et al. Novel role of extracellular matrix protein 1 (ECM1) in cardiac aging and myocardial infarction. PLoS One. 2019;14(2):e0212230. doi:10.1371/journal.pone.0212230

187. Chen HX, Yang ZY, Hou HT, Wang J, Wang XL, Yang Q, Liu L, He GW. Novel mutations of TCTN3/LTBP2 with cellular function changes in congenital heart disease associated with polydactyly. J Cell Mol Med. 2020;24(23):13751-13762. doi:10.1111/jcmm. 15950

188. El Shamieh S, Stathopoulou MG, Bonnefond A, Ndiaye NC, Lecoeur C, Meyre D, Dadé S, Chedid P, Salami A, Shahabi P, et al. Obesity status modifies the association between $\mathrm{rs} 7556897 \mathrm{~T}>\mathrm{C}$ in the intergenic region SLC19A3-CCL20 and blood pressure in French children. Clin Chem Lab Med. 2020;58(11):1819-1827. doi:10.1515/cclm-2019-0292

189. Mastorakos G, Zapanti E. The hypothalamic-pituitary-adrenal axis in the neuroendocrine regulation of food intake and obesity: the role of corticotropin releasing hormone. Nutr Neurosci. 2004;7(5-6):271-280. doi:10.1080/10284150400020516

190. Yang H, Graham LC, Reagan AM, Grabowska WA, Schott WH, Howell GR. Transcriptome profiling of brain myeloid cells revealed activation of Itgal, Trem1, and Spp1 in western diet-induced obesity. J Neuroinflammation. 2019;16(1):169. doi:10.1186/s12974-019-1527-Z

191. Du Y, Li S, Cui CJ, Zhang Y, Yang SH, Li JJ. Leptin decreases the expression of low-density lipoprotein receptor via PCSK9 pathway: linking dyslipidemia with obesity. J Transl Med. 2016;14(1):276. doi:10.1186/s12967-016-1032-4

192. Hams E, Roberts J, Bermingham R, Hogan AE, O'Shea D, O'Neill L, Fallon PG. Role for Retinoic Acid-Related Orphan Receptor Alpha (ROR $\alpha)$ Expressing Macrophages in Diet-Induced Obesity. Front Immunol. 2020;11:1966. doi:10.3389/fimmu.2020.01966

193. Moreno-Navarrete JM, Latorre J, Lluch A, Ortega FJ, Comas F, Arnoriaga-Rodríguez M, Ricart W, Fernández-Real JM. Lysozyme is a component of the innate immune system linked to obesity associated-chronic low-grade inflammation and altered glucose tolerance. Clin Nutr. 2021;40(3):1420-1429. doi:10.1016/j.clnu.2020.08.036 
194. Lee S. The association of genetically controlled $\mathrm{CpG}$ methylation (cg158269415) of protein tyrosine phosphatase, receptor type N2 (PTPRN2) with childhood obesity. Sci Rep. 2019;9(1):4855. doi:10.1038/s41598-01940486-w

195. Soussi H, Reggio S, Alili R, Prado C, Mutel S, Pini M, Rouault C, Clément K, Dugail I. DAPK2 Downregulation Associates With Attenuated Adipocyte Autophagic Clearance in Human Obesity. Diabetes. 2015;64(10):3452-3463. doi:10.2337/db14-1933

196. Inoue K, Maeda N, Mori T, Sekimoto R, Tsushima Y, Matsuda K, Yamaoka M, Suganami T, Nishizawa H, Ogawa $Y$ et al. Possible involvement of Opa-interacting protein 5 in adipose proliferation and obesity. PLoS One. 2014;9(2):e87661. doi:10.1371/journal.pone.0087661

197. Salas-Pérez F, Cuevas-Sierra A, Cuervo M, Goni L, Milagro FI, Martínez JA, Riezu-Boj JI. Differentially methylated regions (DMRs) in PON3 gene between responders and non-responders to a weight loss dietary intervention: a new tool for precision management of obesity. Epigenetics. 2021;1-12. doi:10.1080/15592294.2021.1873629

198. Lee JH, Zhang D, Kwak SE, Shin HE, Song W. Effects of Exercise and a High-Fat, High-Sucrose Restriction Diet on Metabolic Indicators, Nr4a3, and Mitochondria-Associated Protein Expression in the Gastrocnemius Muscles of Mice with Diet-Induced Obesity. J Obes Metab Syndr. 2021;10.7570/jomes20043. doi:10.7570/jomes20043

199. Han CY, Kang I, Harten IA, Gebe JA, Chan CK, Omer M, Alonge KM, den Hartigh LJ, Gomes Kjerulf D, Goodspeed L, et al. AdipocyteDerived Versican and Macrophage-Derived Biglycan Control Adipose Tissue Inflammation in Obesity. Cell Rep. 2020;31(13):107818. doi:10.1016/j.celrep.2020.107818

200. Buchner DA, Geisinger JM, Glazebrook PA, Morgan MG, Spiezio SH, Kaiyala KJ, Schwartz MW, Sakurai T, Furley AJ, Kunze DL, et al. The juxtaparanodal proteins CNTNAP2 and TAG1 regulate diet-induced obesity. Mamm Genome. 2012;23(7-8):431-442. doi:10.1007/s00335-012-9400-8

201. Yu GI, Song DK, Shin DH. Associations of IL1RAP and IL1RL1 gene polymorphisms with obesity and inflammation mediators. Inflamm Res. 2020;69(2):191-202. doi:10.1007/s00011-019-01307-y 
202. Shi Y, Long F. Hedgehog signaling via Gli2 prevents obesity induced by high-fat diet in adult mice. Elife. 2017;6:e31649. doi:10.7554/eLife.31649

203. Jo J, Sull JW, Park EJ, Jee SH. Effects of smoking and obesity on the association between CDH13 (rs3865188) and adiponectin among Korean men: the KARE study. Obesity (Silver Spring). 2012;20(8):1683-1687. doi:10.1038/oby.2011.128

204. Zhang L, Reidy SP, Nicholson TE, Lee HJ, Majdalawieh A, Webber C, Stewart BR, Dolphin P, Ro HS. The role of AEBP1 in sex-specific dietinduced obesity. Mol Med. 2005;11(1-12):39-47. doi:10.2119/200500021.Ro

205. Han CY, Kang I, Harten IA, Gebe JA, Chan CK, Omer M, Alonge KM, den Hartigh LJ, Gomes Kjerulf D, Goodspeed L, et al. AdipocyteDerived Versican and Macrophage-Derived Biglycan Control Adipose Tissue Inflammation in Obesity. Cell Rep. 2020;31(13):107818. doi:10.1016/j.celrep.2020.107818

206. Martínez-Martínez E, Rodríguez C, Galán M, Miana M, Jurado-López R, Bartolomé MV, Luaces M, Islas F, Martínez-González J, López-Andrés $\mathrm{N}$, et al. The lysyl oxidase inhibitor ( $\beta$-aminopropionitrile) reduces leptin profibrotic effects and ameliorates cardiovascular remodeling in dietinduced obesity in rats. J Mol Cell Cardiol. 2016;92:96-104. doi:10.1016/j.yjmcc.2016.01.012

207. Yu GI, Song DK, Shin DH. Associations of IL1RAP and IL1RL1 gene polymorphisms with obesity and inflammation mediators. Inflamm Res. 2020;69(2):191-202. doi:10.1007/s00011-019-01307-y

208. Wolff G, Taranko AE, Meln I, Weinmann J, Sijmonsma T, Lerch S, Heide D, Billeter AT, Tews D, Krunic D, et al. Diet-dependent function of the extracellular matrix proteoglycan Lumican in obesity and glucose homeostasis. Mol Metab. 2019;19:97-106. doi:10.1016/j.molmet.2018.10.007

209. Liu X, Jiang C, Yang P. Association of single nucleotide polymorphisms in the 5' upstream region of the C4BPA gene with essential hypertension in a northeastern Han Chinese population. Mol Med Rep. 2017;16(2):1289-1297. doi:10.3892/mmr.2017.6736 
210. Zhang Y, Shen J, He X, Zhang K, Wu S, Xiao B, Zhou X, Phillips $\mathrm{RS}$, Gao P, Jeunemaitre $\mathrm{X}$, et al. A rare variant at the KYNU gene is associated with kynureninase activity and essential hypertension in the Han Chinese population. Circ Cardiovasc Genet. 2011;4(6):687-694. doi:10.1161/CIRCGENETICS.110.959064

211. Pei Q, Yang L, Tan HY, Liu SK, Liu Y, Huang L, Li RH, Wan Q, Huang J, Guo CX, et al. Effects of genetic variants in UGT1A1, SLCO1B3, $\mathrm{ABCB} 1, \mathrm{ABCC} 2, \mathrm{ABCG} 2, \mathrm{ORM} 1$ on PK/PD of telmisartan in Chinese patients with mild to moderate essential hypertension $\square$. Int J Clin Pharmacol Ther. 2017;55(8):659-665. doi:10.5414/CP202744

212. Tang D, Fakiola M, Syn G, Anderson D, Cordell HJ, Scaman ESH, Davis E, Miles SJ, McLeay T, Jamieson SE, et al. Arylsulphatase A Pseudodeficiency (ARSA-PD), hypertension and chronic renal disease in Aboriginal Australians. Sci Rep. 2018;8(1):10912. doi:10.1038/s41598-01829279-9

213. Durgin BG, Hahn SA, Schmidt HM, Miller MP, Hafeez N, Mathar I, Freitag D, Sandner P, Straub AC. Loss of smooth muscle CYB5R3 amplifies angiotensin II-induced hypertension by increasing sGC heme oxidation. JCI Insight. 2019;4(19):e129183. doi:10.1172/jci.insight.129183

214. Lai CQ, Parnell LD, Troen AM, Shen J, Caouette H, Warodomwichit D, Lee YC, Crott JW, Qiu WQ, Rosenberg IH, et al. MAT1A variants are associated with hypertension, stroke, and markers of DNA damage and are modulated by plasma vitamin B-6 and folate. Am J Clin Nutr. 2010;91(5):1377-1386. doi:10.3945/ajen.2009.28923

215. Lipphardt M, Dihazi H, Maas JH, Schäfer AK, Amlaz SI, Ratliff BB, Koziolek MJ, Wallbach M. Syndecan-4 as a Marker of Endothelial Dysfunction in Patients with Resistant Hypertension. J Clin Med. 2020;9(9):3051. doi:10.3390/jcm9093051

216. Kho J, Tian X, Wong WT, Bertin T, Jiang MM, Chen S, Jin Z, Shchelochkov OA, Burrage LC, Reddy AK, et al. Argininosuccinate Lyase Deficiency Causes an Endothelial-Dependent Form of Hypertension. Am J Hum Genet. 2018;103(2):276-287. doi:10.1016/j.ajhg.2018.07.008

217. Yang HC, Liang YJ, Chen JW, Chiang KM, Chung CM, Ho HY, Ting CT, Lin TH, Sheu SH, Tsai WC, et al. Identification of IGF1, SLC4A4, WWOX, and SFMBT1 as hypertension susceptibility genes in Han Chinese 
with a genome-wide gene-based association study. PLoS One. 2012;7(3):e32907. doi:10.1371/journal.pone.0032907

218. Wu T, Zhang BQ, Raelson J, Yao YM, Wu HD, Xu ZX, MaroisBlanchet FC, Tahir MR, Wang Y, Bradley WE, et al. Analysis of the association of EPHB6, EFNB1 and EFNB3 variants with hypertension risks in males with hypogonadism. Sci Rep. 2018;8(1):14497. doi:10.1038/s41598-018-32836-X

219. Keranov S, Dörr O, Jafari L, Liebetrau C, Keller T, Troidl C, Kriechbaum S, Voss S, Richter M, Tello K, et al. SPARCL1 as a biomarker of maladaptive right ventricular remodelling in pulmonary hypertension. Biomarkers. 2020;25(3):290-295. doi:10.1080/1354750X.2020.1745889

220. Oguri M, Kato K, Yokoi K, Watanabe S, Metoki N, Yoshida H, Satoh $\mathrm{K}$, Aoyagi Y, Nishigaki Y, Yoshida $\mathrm{H}$, et al. Association of polymorphisms of THBS2 and HSPA8 with hypertension in Japanese individuals with chronic kidney disease. Mol Med Rep. 2009;2(2):205-211. doi:10.3892/mmr_00000085

221. Wang Y, Hamet P, Thorin E, Tremblay J, Raelson J, Wu Z, Luo H, Jin W, Lavoie JL, Peng J, et al. Reduced blood pressure after smooth muscle EFNB2 deletion and the potential association of EFNB2 mutation with human hypertension risk. Eur J Hum Genet. 2016;24(12):1817-1825. doi:10.1038/ejhg.2016.105

222. Xu T, Shao L, Wang A, Liang R, Lin Y, Wang G, Zhao Y, Hu J, Liu S. CD248 as a novel therapeutic target in pulmonary arterial hypertension. Clin Transl Med. 2020;10(5):e175. doi:10.1002/ctm2.175

223. Cheng Q, Pan J, Zhou ZL, Yin F, Xie HY, Chen PP, Li JY, Zheng PQ, Zhou L, Zhang W, et al. Caspase-11/4 and gasdermin D-mediated pyroptosis contributes to podocyte injury in mouse diabetic nephropathy. Acta Pharmacol Sin. 2020;10.1038/s41401-020-00525-z. doi:10.1038/s41401-020-00525-Z

224. Jiao X, Zhang D, Hong Q, Yan L, Han Q, Shao F, Cai G, Chen X, Zhu H. Netrin-1 works with UNC5B to regulate angiogenesis in diabetic kidney disease. Front Med. 2020;14(3):293-304. doi:10.1007/s11684-0190715-7

225. Uehara G, Suzuki D, Toyoda M, Umezono T, Sakai H. Glomerular expression of platelet-derived growth factor (PDGF)-A, -B chain and PDGF 
receptor-alpha, -beta in human diabetic nephropathy. Clin Exp Nephrol. 2004;8(1):36-42. doi:10.1007/s10157-003-0265-8

226. Gregg T, Sdao SM, Dhillon RS, Rensvold JW, Lewandowski SL, Pagliarini DJ, Denu JM, Merrins MJ. Obesity-dependent CDK1 signaling stimulates mitochondrial respiration at complex $\mathrm{I}$ in pancreatic $\beta$-cells. $\mathrm{J}$ Biol Chem. 2019;294(12):4656-4666. doi:10.1074/jbc.RA118.006085

227. Fang H, Luo X, Wang Y, Liu N, Fu C, Wang H, Fang Y, Shi W, Zhang Y, Zeng $\mathrm{C}$, et al. Correlation between single nucleotide polymorphisms of the ACTA2 gene and coronary artery stenosis in patients with type 2 diabetes mellitus. Exp Ther Med. 2014;7(4):970-976. doi:10.3892/etm.2014.1510

228. Demirsoy İH, Ertural DY, Balci Ş, Çınkır Ü, Sezer K, Tamer L, Aras N. Profiles of Circulating MiRNAs Following Metformin Treatment in Patients with Type 2 Diabetes. J Med Biochem. 2018;37(4):499-506. doi:10.2478/jomb-2018-0009

229. Hourigan ST, Solly EL, Nankivell VA, Ridiandries A, Weimann BM, Henriquez R, Tepper ER, Zhang JQJ, Tsatralis T, Clayton ZE, et al. The regulation of miRNAs by reconstituted high-density lipoproteins in diabetesimpaired angiogenesis. Sci Rep. 2018;8(1):13596. doi:10.1038/s41598-01832016-x

230. Safar HA, Chehadeh SEH, Abdel-Wareth L, Haq A, Jelinek HF, ElGhazali G, Anouti FA. Vitamin D receptor gene polymorphisms among Emirati patients with type 2 diabetes mellitus. J Steroid Biochem Mol Biol. 2018;175:119-124. doi:10.1016/j.jsbmb.2017.03.012

231. Zmuda EJ, Qi L, Zhu MX, Mirmira RG, Montminy MR, Hai T. The roles of ATF3, an adaptive-response gene, in high-fat-diet-induced diabetes and pancreatic beta-cell dysfunction. Mol Endocrinol. 2010;24(7):14231433. doi:10.1210/me.2009-0463

232. Boese EA, Tollefson MR, Schnieders MJ, Darbro BW, Alward WLM, Fingert JH. Novel Intragenic PAX6 Deletion in a Pedigree with Aniridia, Morbid Obesity, and Diabetes. Curr Eye Res. 2020;45(1):91-96. doi:10.1080/02713683.2019.1649704

233. Suhara T, Baba Y, Shimada BK, Higa JK, Matsui T. The mTOR Signaling Pathway in Myocardial Dysfunction in Type 2 Diabetes Mellitus. Curr Diab Rep. 2017;17(6):38. doi:10.1007/s11892-017-0865-4 
234. Cabiati M, Randazzo E, Salvadori C, Peroni D, Federico G, Del Ry S. Circulating microRNAs associated with C-type natriuretic peptide in childhood obesity. $\quad$ Peptides. 2020;133:170387. doi:10.1016/j.peptides.2020.170387

235. Patankar JV, Chandak PG, Obrowsky S, Pfeifer T, Diwoky C, Uellen A, Sattler W, Stollberger R, Hoefler G, Heinemann A, et al. Loss of intestinal GATA4 prevents diet-induced obesity and promotes insulin sensitivity in mice. Am J Physiol Endocrinol Metab. 2011;300(3):E478E488. doi:10.1152/ajpendo.00457.2010

236. Yan Y, Shi R, Yu X, Sun C, Zang W, Tian H. Identification of atrial fibrillation-associated microRNAs in left and right atria of rheumatic mitral valve disease patients [published correction appears in Genes Genet Syst. 2019;94(4):181]. Genes Genet Syst. 2019;94(1):23-34. doi:10.1266/ggs.1700043

237. Ozono R. New biotechnological methods to reduce oxidative stress in the cardiovascular system: focusing on the Bach1/heme oxygenase-1 pathway. Curr Pharm Biotechnol. 2006;7(2):87-93. doi:10.2174/138920106776597630

238. Qiu C, Wang Y, Zhao H, Qin L, Shi Y, Zhu X, Song L, Zhou X, Chen $\mathrm{J}$, Zhou $\mathrm{H}$, et al. The critical role of SENP1-mediated GATA2 deSUMOylation in promoting endothelial activation in graft arteriosclerosis. Nat Commun. 2017;8:15426. doi:10.1038/ncomms15426

239. Liu XM, Du SL, Miao R, Wang LF, Zhong JC. Targeting the forkhead box protein P1 pathway as a novel therapeutic approach for cardiovascular diseases. Heart Fail Rev. 2020;10.1007/s10741-020-09992-2. doi:10.1007/s10741-020-09992-2

240. Fischer A, Steidl C, Wagner TU, Lang E, Jakob PM, Friedl P, Knobeloch KP, Gessler M. Combined loss of Hey1 and HeyL causes congenital heart defects because of impaired epithelial to mesenchymal transition. Circ Res. 2007;100(6):856-863. doi:10.1161/01.RES.0000260913.95642.3b

241. Hecker M, Thamilarasan M, Koczan D, Schröder I, Flechtner K, Freiesleben S, Füllen G, Thiesen HJ, Zettl UK. MicroRNA expression changes during interferon-beta treatment in the peripheral blood of multiple 
sclerosis patients. Int J Mol Sci. 2013;14(8):16087-16110.. doi:10.3390/ijms140816087

242. Gu X, Liu Y, Wang N, Zhen J, Zhang B, Hou S, Cui Z, Wan Q, Feng H. Transcription of MRPL12 regulated by Nrf2 contributes to the mitochondrial dysfunction in diabetic kidney disease. Free Radic Biol Med. 2021;164:329-340. doi:10.1016/j.freeradbiomed.2021.01.004

243. Zhang D, Gu T, Forsberg E, Efendic S, Brismar K, Gu HF. Genetic and functional effects of membrane metalloendopeptidase on diabetic nephropathy development. Am J Nephrol. 2011;34(5):483-490. doi:10.1159/000333006

244. Bourgeois A, Bonnet S, Breuils-Bonnet S, Habbout K, Paradis R, Tremblay E, Lampron MC, Orcholski ME, Potus F, Bertero T, et al. Inhibition of CHK 1 (Checkpoint Kinase 1) Elicits Therapeutic Effects in Pulmonary Arterial Hypertension. Arterioscler Thromb Vasc Biol. 2019;39(8):1667-1681. doi:10.1161/ATVBAHA.119.312537

\section{Tables}

Table 1 The sequences of primers for quantitative RT-PCR

$\begin{array}{ccc}\text { Genes } & \text { Forward Primers } & \text { Reverse Primers } \\ \text { JUN } & \text { TTCCTCCAGTCCGAGAGCG } & \text { TGAGAAGGTCCGAGTTCTTGG } \\ \text { VCAM1 } & \text { TTGGGAGCCTCAACGGTACT } & \text { GCAATCGTTTTGTATTCAGGGGA } \\ \text { RELA } & \text { TGCGATTCCGCTATAAATGCG } & \text { ACAAGTTCATGTGGATGAGGC } \\ \text { U2AF2 } & \text { ATGTCGGACTTCGACGAGTTC } & \text { CCTGTGCCGATTCTCCTTGT } \\ \text { ADRB2 } & \text { ATGTCGGTTATCGTCCTGGC } & \text { GGTTTGTAGTCGCTCGAACTTG } \\ \text { FN1 } & \text { ATGTGGACCCCTCCTGATAGT } & \text { GCCCAGTGATTTCAGCAAAGG } \\ \text { CDK1 } & \text { AGGTACTTACGGTGTGGTGTAT } & \text { CTCGCTTTCAAGTCTGATCTTCT } \\ \text { TK1 } & \text { AGTGCCTGGTCATCAAGTATGC } & \text { GCTGCCACAATTACTGTCTTGC } \\ \text { A2M } & \text { GGCAGAATTTCCGCTTAGAGG } & \text { CACACACGGACACATTCATCT } \\ \text { ACTA2 } & \text { CCCAGACATCAGGGAGTAATGG } & \text { TCTATCGGATACTTCAGCGTCA }\end{array}$

Table 2 The statistical metrics for key differentially expressed genes (DEGs) 
bioRxiv preprint doi: https://doi.org/10.1101/2021.03.28.437386; this version posted May 10, 2021. The copyright holder for this preprint (which was not certified by peer review) is the author/funder. All rights reserved. No reuse allowed without permission.

\begin{tabular}{|c|c|c|c|c|c|c|}
\hline PENK & 4.860097 & $2.31 \mathrm{E}-06$ & $6.52 \mathrm{E}-05$ & 4.724639 & Up & proenkephalin \\
\hline CYP4F11 & 4.557396 & $1.08 \mathrm{E}-08$ & $6.35 \mathrm{E}-07$ & 5.718164 & Up & cytochrome P450 family 4 subfamily F member 11 \\
\hline SAA1 & 4.462926 & $1.67 \mathrm{E}-10$ & $1.47 \mathrm{E}-08$ & 6.389109 & Up & serum amyloid A1 \\
\hline CARTPT & 4.198389 & 4.41E-06 & 0.000113 & 4.591213 & Up & CART prepropeptide \\
\hline SUCNR1 & 4.145076 & $1.59 \mathrm{E}-08$ & $8.96 \mathrm{E}-07$ & 5.651175 & Up & succinate receptor 1 \\
\hline ORM1 & 3.813821 & $8.85 \mathrm{E}-06$ & 0.000205 & 4.443579 & Up & orosomucoid 1 \\
\hline CRP & 3.755592 & $3.74 \mathrm{E}-42$ & $3.70 \mathrm{E}-39$ & 13.60499 & Up & C-reactive protein \\
\hline ITGAX & 3.641001 & 2.84E-06 & 7.77E-05 & 4.681713 & Up & integrin subunit alpha $X$ \\
\hline APCS & 3.628065 & $6.73 \mathrm{E}-19$ & $2.00 \mathrm{E}-16$ & 8.87927 & Up & amyloid P component, serum \\
\hline CA12 & 3.545671 & $6.04 \mathrm{E}-13$ & $8.54 \mathrm{E}-11$ & 7.199606 & Up & carbonic anhydrase 12 \\
\hline CACNA2D3 & 3.499413 & 2.91E-07 & $1.12 \mathrm{E}-05$ & 5.128975 & Up & calcium voltage-gated channel auxiliary subunit alpha2delta 3 \\
\hline SLITRK6 & 3.470335 & $1.29 \mathrm{E}-14$ & $2.33 \mathrm{E}-12$ & 7.706578 & Up & SLIT and NTRK like family member 6 \\
\hline F11 & 3.438039 & $1.28 \mathrm{E}-11$ & $1.45 \mathrm{E}-09$ & 6.771333 & Up & coagulation factor XI \\
\hline CHI3L2 & 3.353492 & 0.003527 & 0.025134 & 2.917594 & Up & chitinase 3 like 2 \\
\hline MUC15 & 3.285 & $5.44 \mathrm{E}-05$ & 0.000915 & 4.035669 & Up & mucin 15 , cell surface associated \\
\hline MSMB & 3.271431 & 0.007069 & 0.041925 & 2.693557 & Up & microseminoprotein beta \\
\hline UCA1 & 3.175529 & 4.97E-12 & $6.20 \mathrm{E}-10$ & 6.906567 & Up & urothelial cancer associated 1 \\
\hline C4BPA & 3.156304 & 7.62E-08 & $3.42 \mathrm{E}-06$ & 5.375891 & Up & complement component 4 binding protein alpha \\
\hline SERPINA6 & 3.094247 & $1.58 \mathrm{E}-14$ & $2.79 \mathrm{E}-12$ & 7.680819 & Up & serpin family A member 6 \\
\hline FGFBP1 & 3.063736 & $5.24 \mathrm{E}-05$ & 0.000889 & 4.044509 & Up & fibroblast growth factor binding protein 1 \\
\hline FGA & 3.039962 & $2.40 \mathrm{E}-05$ & 0.000469 & 4.224153 & Up & fibrinogen alpha chain \\
\hline HAO1 & 2.988341 & 0.008352 & 0.047393 & 2.6375 & Up & hydroxyacid oxidase 1 \\
\hline PIGR & 2.974332 & $3.80 \mathrm{E}-22$ & $1.48 \mathrm{E}-19$ & 9.676431 & Up & polymeric immunoglobulin receptor \\
\hline PPY & 2.954157 & $6.32 \mathrm{E}-32$ & $3.61 \mathrm{E}-29$ & 11.75944 & Up & pancreatic polypeptide \\
\hline ALDH1A2 & 2.942058 & 0.000702 & 0.00735 & 3.38886 & Up & aldehyde dehydrogenase 1 family member $\mathrm{A} 2$ \\
\hline PSTPIP2 & 2.936601 & 0.000134 & 0.001922 & 3.81981 & Up & proline-serine-threonine phosphatase interacting protein 2 \\
\hline SAA2 & 2.886413 & 0.000194 & 0.002625 & 3.726124 & Up & serum amyloid A2 \\
\hline SNORA62 & 2.866455 & 0.000796 & 0.008139 & 3.354352 & Up & small nucleolar RNA, H/ACA box 62 \\
\hline LRG1 & 2.815781 & 3.99E-09 & $2.54 \mathrm{E}-07$ & 5.884742 & Up & leucine rich alpha-2-glycoprotein 1 \\
\hline C16orf54 & 2.814328 & 0.000711 & 0.00743 & 3.385114 & Up & chromosome 16 open reading frame 54 \\
\hline RGS1 & 2.76984 & 0.000395 & 0.004659 & 3.543409 & Up & regulator of G protein signaling 1 \\
\hline TMEM132B & 2.721191 & $3.82 \mathrm{E}-09$ & $2.44 \mathrm{E}-07$ & 5.891843 & Up & transmembrane protein 132B \\
\hline AMBN & 2.717325 & 0.005864 & 0.036494 & 2.75531 & Up & ameloblastin \\
\hline STX19 & 2.699996 & $1.05 \mathrm{E}-05$ & 0.000235 & 4.407223 & Up & syntaxin 19 \\
\hline RAB33A & 2.694358 & 0.006201 & 0.038131 & 2.736957 & Up & RAB33A, member RAS oncogene family \\
\hline KYNU & 2.63086 & 0.000374 & 0.004463 & 3.557871 & Up & kynureninase \\
\hline LOC389834 & 2.602019 & $1.62 \mathrm{E}-11$ & 1.79E-09 & 6.736442 & Up & ankyrin repeat domain 57 pseudogene \\
\hline SLC17A1 & 2.594486 & 0.003475 & 0.024908 & 2.922231 & Up & solute carrier family 17 member 1 \\
\hline ADRB2 & 2.548793 & 0.001254 & 0.011599 & 3.226378 & Up & adrenoceptor beta 2 \\
\hline AADAC & 2.519181 & 0.004121 & 0.028255 & 2.868728 & Up & arylacetamide deacetylase \\
\hline VNN1 & 2.51097 & 4.17E-09 & $2.65 \mathrm{E}-07$ & 5.877277 & Up & vanin 1 \\
\hline SLPI & 2.505407 & $9.85 \mathrm{E}-11$ & $9.02 \mathrm{E}-09$ & 6.469308 & Up & secretory leukocyte peptidase inhibitor \\
\hline SLCO1A2 & 2.502753 & 0.000923 & 0.009176 & 3.313154 & Up & solute carrier organic anion transporter family member $1 \mathrm{~A} 2$ \\
\hline
\end{tabular}


bioRxiv preprint doi: https://doi.org/10.1101/2021.03.28.437386; this version posted May 10, 2021. The copyright holder for this preprint (which was not certified by peer review) is the author/funder. All rights reserved. No reuse allowed without permission.

\begin{tabular}{|c|c|c|c|c|c|c|}
\hline ST8SIA1 & 2.488529 & $2.41 \mathrm{E}-06$ & $6.74 \mathrm{E}-05$ & 4.715297 & Up & ST8 alpha-N-acetyl-neuraminide alpha-2,8-sialyltransferase 1 \\
\hline NRAP & 2.399155 & $4.27 \mathrm{E}-05$ & 0.000748 & 4.092199 & Up & nebulin related anchoring protein \\
\hline HLA-DRA & 2.388682 & 2.35E-08 & $1.25 \mathrm{E}-06$ & 5.584286 & Up & major histocompatibility complex, class II, DR alpha \\
\hline CHI3L1 & 2.387761 & $2.28 \mathrm{E}-06$ & $6.49 \mathrm{E}-05$ & 4.72652 & Up & chitinase 3 like 1 \\
\hline SLC19A3 & 2.385339 & 0.001489 & 0.013224 & 3.176838 & Up & solute carrier family 19 member 3 \\
\hline AMBP & 2.361932 & $1.13 \mathrm{E}-11$ & $1.30 \mathrm{E}-09$ & 6.788459 & Up & alpha-1-microglobulin/bikunin precursor \\
\hline REG3A & 2.360754 & $1.23 \mathrm{E}-16$ & $2.77 \mathrm{E}-14$ & 8.279959 & Up & regenerating family member 3 alpha \\
\hline SLITRK1 & 2.357923 & 0.000111 & 0.001645 & 3.864203 & Up & SLIT and NTRK like family member 1 \\
\hline IDUA & 2.326669 & $4.20 \mathrm{E}-06$ & 0.000109 & 4.601026 & Up & alpha-L-iduronidase \\
\hline GLB1L3 & 2.31374 & 0.00073 & 0.007589 & 3.377954 & Up & galactosidase beta 1 like 3 \\
\hline CCL20 & 2.287171 & $1.33 \mathrm{E}-06$ & 4.22E-05 & 4.834695 & Up & $\mathrm{C}-\mathrm{C}$ motif chemokine ligand 20 \\
\hline VNN2 & 2.286735 & 7.10E-06 & 0.000169 & 4.490666 & Up & $\operatorname{vanin} 2$ \\
\hline LOC100287042 & 2.281235 & $3.41 \mathrm{E}-05$ & 0.000622 & 4.144375 & Up & uncharacterized LOC100287042 \\
\hline SLC25A19 & 2.270193 & $2.32 \mathrm{E}-06$ & $6.56 \mathrm{E}-05$ & 4.723098 & Up & solute carrier family 25 member 19 \\
\hline GABRE & 2.249575 & 0.002005 & 0.016626 & 3.089455 & Up & gamma-aminobutyric acid type A receptor subunit epsilon \\
\hline NR1H4 & 2.247257 & 0.001413 & 0.012715 & 3.192038 & Up & nuclear receptor subfamily 1 group $\mathrm{H}$ member 4 \\
\hline TSPAN8 & 2.233034 & $1.85 \mathrm{E}-12$ & $2.50 \mathrm{E}-10$ & 7.045428 & Up & tetraspanin 8 \\
\hline CEACAM7 & 2.226633 & $5.58 \mathrm{E}-08$ & 2.64E-06 & 5.43174 & Up & CEA cell adhesion molecule 7 \\
\hline CA4 & 2.191782 & 0.006301 & 0.038587 & 2.731677 & Up & carbonic anhydrase 4 \\
\hline CERS1 & 2.18001 & 0.006481 & 0.039298 & 2.722409 & Up & ceramide synthase 1 \\
\hline CDH17 & 2.177532 & 0.002096 & 0.017108 & 3.076347 & Up & cadherin 17 \\
\hline PPP1R1B & 2.15086 & 0.00586 & 0.036487 & 2.755516 & Up & protein phosphatase 1 regulatory inhibitor subunit $1 \mathrm{~B}$ \\
\hline ACSF3 & 2.095319 & 0.000462 & 0.005303 & 3.501601 & Up & acyl-CoA synthetase family member 3 \\
\hline FFAR1 & 2.080867 & 0.005375 & 0.03423 & 2.783637 & Up & free fatty acid receptor 1 \\
\hline SERPINA10 & 2.046459 & $8.11 \mathrm{E}-06$ & 0.00019 & 4.462269 & Up & serpin family A member 10 \\
\hline FIGNL1 & 2.041234 & 4.60E-05 & 0.000794 & 4.07531 & Up & fidgetin like 1 \\
\hline $\mathrm{ADH} 1 \mathrm{C}$ & 2.037037 & 4.35E-06 & 0.000112 & 4.594134 & Up & alcohol dehydrogenase 1C (class I), gamma polypeptide \\
\hline HLA-DMB & 2.032997 & 0.005544 & 0.035075 & 2.773628 & Up & major histocompatibility complex, class II, DM beta \\
\hline SLC34A2 & 2.032368 & $2.84 \mathrm{E}-05$ & 0.00054 & 4.186165 & Up & solute carrier family 34 member 2 \\
\hline SPATA2L & 2.020068 & 5.03E-05 & 0.00086 & 4.054045 & Up & spermatogenesis associated 2 like \\
\hline $\mathrm{HCN} 3$ & 1.997149 & $5.93 \mathrm{E}-08$ & $2.76 \mathrm{E}-06$ & 5.420837 & Up & hyperpolarization activated cyclic nucleotide gated potassium channel 3 \\
\hline KCTD16 & 1.962394 & 0.003351 & 0.024334 & 2.933559 & Up & potassium channel tetramerization domain containing 16 \\
\hline PKLR & 1.928837 & $3.46 \mathrm{E}-06$ & $9.23 \mathrm{E}-05$ & 4.641383 & Up & pyruvate kinase $\mathrm{L} / \mathrm{R}$ \\
\hline DUOXA2 & 1.924972 & $1.06 \mathrm{E}-06$ & 3.44E-05 & 4.880573 & Up & dual oxidase maturation factor 2 \\
\hline $\mathrm{FA} 2 \mathrm{H}$ & 1.92455 & 0.002863 & 0.021636 & 2.982087 & Up & fatty acid 2-hydroxylase \\
\hline TUB & 1.917857 & $1.09 \mathrm{E}-07$ & 4.74E-06 & 5.311478 & Up & TUB bipartite transcription factor \\
\hline PID1 & 1.916368 & 0.004177 & 0.028518 & 2.864483 & Up & phosphotyrosine interaction domain containing 1 \\
\hline MLIP & 1.913434 & $2.16 \mathrm{E}-07$ & 8.57E-06 & 5.184749 & Up & muscular LMNA interacting protein \\
\hline GCNT3 & 1.908059 & $1.93 \mathrm{E}-08$ & $1.06 \mathrm{E}-06$ & 5.618207 & Up & glucosaminyl ( $\mathrm{N}$-acetyl) transferase 3 , mucin type \\
\hline OTOGL & 1.892097 & $1.00 \mathrm{E}-04$ & 0.001501 & 3.890689 & Up & otogelin like \\
\hline CDKN2A & 1.883974 & 0.00094 & 0.009327 & 3.307815 & Up & cyclin dependent kinase inhibitor $2 \mathrm{~A}$ \\
\hline MACROD1 & 1.872259 & 0.007006 & 0.04162 & 2.696554 & Up & mono-ADP ribosylhydrolase 1 \\
\hline VCAM1 & 1.871446 & $3.76 \mathrm{E}-06$ & $9.91 \mathrm{E}-05$ & 4.624033 & Up & vascular cell adhesion molecule 1 \\
\hline
\end{tabular}




\begin{tabular}{|c|c|c|c|c|c|c|}
\hline LGALS4 & 1.84876 & $9.70 \mathrm{E}-06$ & 0.00022 & 4.423816 & Up & galectin 4 \\
\hline TMEM143 & 1.846802 & 0.001428 & 0.012824 & 3.188908 & Up & transmembrane protein 143 \\
\hline $\mathrm{CRH}$ & 1.827098 & $2.35 \mathrm{E}-06$ & $6.62 \mathrm{E}-05$ & 4.720469 & Up & corticotropin releasing hormone \\
\hline WDR72 & 1.824566 & 0.008691 & 0.048752 & 2.623982 & Up & WD repeat domain 72 \\
\hline WDR24 & 1.819369 & 0.001795 & 0.015187 & 3.122228 & Up & WD repeat domain 24 \\
\hline KCNQ1 & 1.817087 & $1.48 \mathrm{E}-05$ & 0.000311 & 4.331946 & Up & potassium voltage-gated channel subfamily $Q$ member 1 \\
\hline NR4A2 & 1.815373 & $1.42 \mathrm{E}-10$ & $1.27 \mathrm{E}-08$ & 6.413344 & Up & nuclear receptor subfamily 4 group A member 2 \\
\hline NECAB2 & 1.813422 & 0.001222 & 0.011371 & 3.233672 & Up & N-terminal EF-hand calcium binding protein 2 \\
\hline URB2 & 1.811519 & $8.32 \mathrm{E}-05$ & 0.001288 & 3.93486 & Up & URB2 ribosome biogenesis homolog \\
\hline ALB & 1.794782 & $1.48 \mathrm{E}-05$ & 0.000311 & 4.331897 & Up & albumin \\
\hline KCNH6 & 1.77235 & $5.47 \mathrm{E}-05$ & 0.000915 & 4.03459 & Up & potassium voltage-gated channel subfamily $\mathrm{H}$ member 6 \\
\hline CNGA1 & 1.769682 & $5.46 \mathrm{E}-05$ & 0.000915 & 4.035139 & Up & cyclic nucleotide gated channel subunit alpha 1 \\
\hline MAT1A & 1.766294 & 0.00023 & 0.003021 & 3.683726 & Up & methionine adenosyltransferase $1 \mathrm{~A}$ \\
\hline SLC24A3 & 1.759392 & 0.004454 & 0.029889 & 2.844072 & Up & solute carrier family 24 member 3 \\
\hline DAB2IP & 1.759192 & $7.46 \mathrm{E}-07$ & $2.52 \mathrm{E}-05$ & 4.949072 & Up & $\mathrm{DAB} 2$ interacting protein \\
\hline SNORA20 & 1.756052 & 0.003502 & 0.025024 & 2.919876 & Up & small nucleolar RNA, H/ACA box 20 \\
\hline ARRDC2 & 1.750189 & $6.94 \mathrm{E}-06$ & 0.000166 & 4.495401 & Up & arrestin domain containing 2 \\
\hline PLIN5 & 1.739472 & 0.006153 & 0.037942 & 2.739541 & Up & perilipin 5 \\
\hline SLC6A20 & 1.736959 & 0.008503 & 0.047957 & 2.631413 & Up & solute carrier family 6 member 20 \\
\hline $\mathrm{CD} 74$ & 1.736016 & $2.32 \mathrm{E}-11$ & $2.48 \mathrm{E}-09$ & 6.684348 & Up & CD74 molecule \\
\hline DUOXA1 & 1.726737 & $5.87 \mathrm{E}-05$ & 0.000971 & 4.018021 & Up & dual oxidase maturation factor 1 \\
\hline $\mathrm{CP}$ & 1.7227 & $2.93 \mathrm{E}-10$ & $2.44 \mathrm{E}-08$ & 6.302509 & Up & ceruloplasmin \\
\hline ALDOB & 1.721723 & 0.000101 & 0.001509 & 3.889197 & Up & aldolase, fructose-bisphosphate B \\
\hline OIP5 & 1.717334 & 0.008267 & 0.047125 & 2.640977 & Up & Opa interacting protein 5 \\
\hline HLA-F-AS1 & 1.716992 & 4.92E-06 & 0.000124 & 4.568213 & Up & HLA-F antisense RNA 1 \\
\hline PCDH10 & 1.715746 & 0.001468 & 0.01308 & 3.18087 & Up & protocadherin 10 \\
\hline FJX1 & 1.693333 & 0.003956 & 0.027372 & 2.881683 & Up & four-jointed box kinase 1 \\
\hline MAP3K9 & 1.683732 & $9.32 \mathrm{E}-06$ & 0.000214 & 4.432432 & Up & mitogen-activated protein kinase kinase kinase 9 \\
\hline HABP2 & 1.681662 & 0.000412 & 0.004825 & 3.532477 & Up & hyaluronan binding protein 2 \\
\hline BRD7P3 & 1.677208 & 0.000205 & 0.002741 & 3.712458 & Up & bromodomain containing 7 pseudogene 3 \\
\hline SHROOM1 & 1.671713 & $1.55 \mathrm{E}-08$ & $8.74 \mathrm{E}-07$ & 5.656164 & Up & shroom family member 1 \\
\hline PTPRH & 1.669188 & 0.000118 & 0.001725 & 3.85006 & Up & protein tyrosine phosphatase receptor type $\mathrm{H}$ \\
\hline SHANK2 & 1.665031 & 0.000579 & 0.006326 & 3.441284 & Up & SH3 and multiple ankyrin repeat domains 2 \\
\hline PGR & 1.657716 & $1.99 \mathrm{E}-09$ & $1.33 \mathrm{E}-07$ & 5.999007 & Up & progesterone receptor \\
\hline PHLDA3 & 1.65533 & 0.000794 & 0.008137 & 3.354941 & Up & pleckstrin homology like domain family A member 3 \\
\hline S100Z & 1.652261 & 0.00568 & 0.035738 & 2.765729 & Up & S100 calcium binding protein $\mathrm{Z}$ \\
\hline SOCS1 & 1.634331 & 0.003513 & 0.025042 & 2.918905 & Up & suppressor of cytokine signaling 1 \\
\hline ASPSCR1 & 1.624667 & 0.000167 & 0.002316 & 3.764994 & Up & ASPSCR1 tether for SLC2A4, UBX domain containing \\
\hline BIRC3 & 1.618173 & $5.91 \mathrm{E}-09$ & $3.66 \mathrm{E}-07$ & 5.819157 & Up & baculoviral IAP repeat containing 3 \\
\hline C1QTNF4 & 1.614263 & 0.004843 & 0.031685 & 2.817264 & Up & $\mathrm{C} 1 \mathrm{q}$ and $\mathrm{TNF}$ related 4 \\
\hline RNF32 & 1.601341 & 0.005621 & 0.035412 & 2.76913 & Up & ring finger protein 32 \\
\hline VARS2 & 1.58278 & 0.000596 & 0.006463 & 3.433317 & Up & valyl-tRNA synthetase 2 , mitochondrial \\
\hline PLEKHB1 & 1.578123 & $5.54 \mathrm{E}-05$ & 0.000926 & 4.031511 & Up & pleckstrin homology domain containing B1 \\
\hline
\end{tabular}




\begin{tabular}{|c|c|c|c|c|c|c|}
\hline $\mathrm{CDH} 22$ & 1.571917 & 0.005098 & 0.03286 & 2.800754 & Up & cadherin 22 \\
\hline DOCK8 & 1.567052 & 0.004065 & 0.027932 & 2.873092 & Up & dedicator of cytokinesis 8 \\
\hline SERTM1 & 1.564759 & 0.001697 & 0.014507 & 3.13872 & Up & serine rich and transmembrane domain containing 1 \\
\hline ADRB1 & 1.554144 & 0.001395 & 0.012583 & 3.195745 & Up & adrenoceptor beta 1 \\
\hline CALY & 1.543282 & 0.000114 & 0.001673 & 3.858656 & Up & calcyon neuron specific vesicular protein \\
\hline ACSS2 & 1.542 & 7.54E-05 & 0.001186 & 3.958622 & Up & acyl-CoA synthetase short chain family member 2 \\
\hline JMJD4 & 1.540229 & 0.000174 & 0.002405 & 3.754382 & Up & jumonji domain containing 4 \\
\hline STEAP4 & 1.533888 & 0.004097 & 0.028125 & 2.870632 & $\mathrm{Up}$ & STEAP4 metalloreductase \\
\hline OSGIN2 & 1.529591 & $1.60 \mathrm{E}-06$ & 4.91E-05 & 4.798679 & Up & oxidative stress induced growth inhibitor family member 2 \\
\hline SPP1 & 1.527485 & $4.18 \mathrm{E}-11$ & 4.25E-09 & 6.597665 & Up & secreted phosphoprotein 1 \\
\hline ZNF784 & 1.523025 & 0.008388 & 0.047542 & 2.636046 & Up & zinc finger protein 784 \\
\hline RHOT2 & 1.510241 & $1.68 \mathrm{E}-08$ & 9.37E-07 & 5.642248 & Up & ras homolog family member $\mathrm{T} 2$ \\
\hline DPP4 & 1.507531 & $1.17 \mathrm{E}-06$ & $3.76 \mathrm{E}-05$ & 4.860897 & Up & dipeptidyl peptidase 4 \\
\hline DEFB1 & 1.505726 & $5.22 \mathrm{E}-05$ & 0.000885 & 4.045675 & Up & defensin beta 1 \\
\hline FAM20A & 1.500559 & 0.005505 & 0.034873 & 2.775919 & Up & FAM20A golgi associated secretory pathway pseudokinase \\
\hline KLB & 1.489726 & 0.001201 & 0.011223 & 3.238649 & Up & klotho beta \\
\hline CLIP2 & 1.487029 & 0.000132 & 0.001905 & 3.823121 & Up & CAP-Gly domain containing linker protein 2 \\
\hline MVD & 1.483339 & 0.000281 & 0.003571 & 3.631897 & Up & mevalonate diphosphate decarboxylase \\
\hline SCNN1A & 1.482171 & 0.005552 & 0.035114 & 2.773124 & Up & sodium channel epithelial 1 subunit alpha \\
\hline LRRC24 & 1.468999 & 0.000285 & 0.003597 & 3.628672 & Up & leucine rich repeat containing 24 \\
\hline ELL & 1.459712 & 0.002701 & 0.020786 & 2.999815 & Up & elongation factor for RNA polymerase II \\
\hline CCDC85B & 1.454035 & 0.000695 & 0.007327 & 3.391678 & Up & coiled-coil domain containing 85B \\
\hline DENND2D & 1.448171 & 2.07E-06 & $6.02 \mathrm{E}-05$ & 4.746846 & Up & DENN domain containing 2D \\
\hline NR4A3 & 1.443348 & 0.000701 & 0.00735 & 3.389062 & Up & nuclear receptor subfamily 4 group A member 3 \\
\hline PEX7 & 1.441084 & 0.000698 & 0.00735 & 3.39031 & Up & peroxisomal biogenesis factor 7 \\
\hline CASP10 & 1.43516 & 0.001067 & 0.010216 & 3.272233 & Up & caspase 10 \\
\hline RNASE4 & 1.434292 & $8.21 \mathrm{E}-09$ & 4.96E-07 & 5.764056 & Up & ribonuclease A family member 4 \\
\hline GGA1 & 1.422219 & 2.17E-06 & $6.27 \mathrm{E}-05$ & 4.736599 & Up & golgi associated, gamma adaptin ear containing, ARF binding protein 1 \\
\hline ZBTB48 & 1.420898 & $5.67 \mathrm{E}-06$ & 0.00014 & 4.538176 & Up & zinc finger and BTB domain containing 48 \\
\hline ARX & 1.41982 & $4.88 \mathrm{E}-07$ & $1.75 \mathrm{E}-05$ & 5.031034 & Up & aristaless related homeobox \\
\hline HLA-DRB1 & 1.417078 & 0.005289 & 0.033753 & 2.788877 & Up & major histocompatibility complex, class II, DR beta 1 \\
\hline HSD17B2 & 1.41604 & 0.005122 & 0.032969 & 2.799273 & Up & hydroxysteroid 17-beta dehydrogenase 2 \\
\hline FAM98C & 1.412537 & 0.001652 & 0.014229 & 3.146501 & Up & family with sequence similarity 98 member $\mathrm{C}$ \\
\hline KLKB1 & 1.408861 & 0.003203 & 0.023502 & 2.94759 & Up & kallikrein B1 \\
\hline KLHDC1 & 1.40424 & 0.000949 & 0.009368 & 3.305269 & Up & kelch domain containing 1 \\
\hline RAB20 & 1.402783 & 0.007176 & 0.042473 & 2.688558 & Up & RAB20, member RAS oncogene family \\
\hline DUOX2 & 1.400604 & $8.92 \mathrm{E}-06$ & 0.000206 & 4.441768 & Up & dual oxidase 2 \\
\hline CASP1 & 1.396972 & 0.004561 & 0.030411 & 2.836529 & Up & caspase 1 \\
\hline CHN2 & 1.393794 & 0.00846 & 0.047791 & 2.633124 & Up & chimerin 2 \\
\hline $\mathrm{KCNC} 4$ & 1.383783 & 0.001837 & 0.015486 & 3.115314 & Up & potassium voltage-gated channel subfamily $\mathrm{C}$ member 4 \\
\hline ARMC7 & 1.382084 & 3.64E-05 & 0.000655 & 4.128939 & Up & armadillo repeat containing 7 \\
\hline LAT2 & 1.375052 & 0.008875 & 0.049473 & 2.616818 & Up & linker for activation of $\mathrm{T}$ cells family member 2 \\
\hline WFDC2 & 1.361957 & $4.56 \mathrm{E}-05$ & 0.000788 & 4.077326 & Up & WAP four-disulfide core domain 2 \\
\hline
\end{tabular}


bioRxiv preprint doi: https://doi.org/10.1101/2021.03.28.437386; this version posted May 10, 2021. The copyright holder for this preprint (which was not certified by peer review) is the author/funder. All rights reserved. No reuse allowed without permission.

\begin{tabular}{|c|c|c|c|c|c|c|}
\hline NPAS4 & 1.357653 & 0.002985 & 0.022333 & 2.969242 & Up & neuronal PAS domain protein 4 \\
\hline HLA-DPB1 & 1.353913 & 0.008542 & 0.048154 & 2.629871 & Up & major histocompatibility complex, class II, DP beta 1 \\
\hline RARRES2 & 1.349155 & 0.002552 & 0.019943 & 3.017143 & Up & retinoic acid receptor responder 2 \\
\hline RFX1 & 1.349082 & $7.70 \mathrm{E}-05$ & 0.001207 & 3.953595 & Up & regulatory factor $\mathrm{X} 1$ \\
\hline CYP3A5 & 1.33808 & 2.89E-06 & $7.86 \mathrm{E}-05$ & 4.67874 & Up & cytochrome P450 family 3 subfamily A member 5 \\
\hline MIR29C & 1.334143 & 0.000797 & 0.008139 & 3.353784 & Up & microRNA 29c \\
\hline MRPL12 & 1.333729 & 0.001991 & 0.016546 & 3.091565 & Up & mitochondrial ribosomal protein L12 \\
\hline FBXO36 & 1.333024 & $1.23 \mathrm{E}-05$ & 0.000269 & 4.372934 & $\mathrm{Up}$ & F-box protein 36 \\
\hline FAM86DP & 1.328847 & 0.005607 & 0.035369 & 2.76994 & Up & family with sequence similarity 86 member $\mathrm{D}$, pseudogene \\
\hline ARVCF & 1.326161 & $3.31 \mathrm{E}-05$ & 0.00061 & 4.150713 & Up & ARVCF delta catenin family member \\
\hline DEPTOR & 1.318149 & 0.001117 & 0.010593 & 3.259253 & Up & DEP domain containing MTOR interacting protein \\
\hline KCNJ8 & 1.318057 & 0.000238 & 0.003115 & 3.674944 & Up & potassium inwardly rectifying channel subfamily $\mathrm{J}$ member 8 \\
\hline PDZK1IP1 & 1.315801 & $9.18 \mathrm{E}-05$ & 0.001398 & 3.911373 & Up & PDZK1 interacting protein 1 \\
\hline CFB & 1.315099 & $3.82 \mathrm{E}-06$ & 9.99E-05 & 4.621177 & Up & complement factor B \\
\hline CPT1B & 1.308267 & 0.000694 & 0.007327 & 3.391758 & Up & carnitine palmitoyltransferase $1 \mathrm{~B}$ \\
\hline MMRN1 & 1.306941 & 0.000963 & 0.009463 & 3.30117 & Up & multimerin 1 \\
\hline ETV3 & 1.301854 & 0.001294 & 0.011913 & 3.217317 & Up & ETS variant transcription factor 3 \\
\hline DTNB & 1.283314 & 0.005856 & 0.036476 & 2.755748 & Up & dystrobrevin beta \\
\hline MMP1 & 1.282851 & 0.000374 & 0.004463 & 3.557922 & Up & matrix metallopeptidase 1 \\
\hline TMEM176A & 1.282033 & $6.86 \mathrm{E}-10$ & $5.17 \mathrm{E}-08$ & 6.169302 & Up & transmembrane protein $176 \mathrm{~A}$ \\
\hline NR4A1 & 1.277418 & $9.03 \mathrm{E}-10$ & $6.61 \mathrm{E}-08$ & 6.125627 & Up & nuclear receptor subfamily 4 group A member 1 \\
\hline TYMP & 1.269805 & 0.003887 & 0.02702 & 2.887229 & Up & $\begin{array}{l}\text { thymidine phosphorylase } \\
\text { WAS protein homolog associated with actin golgi membranes and }\end{array}$ \\
\hline WHAMMP3 & 1.268427 & 0.00011 & 0.001633 & 3.86674 & Up & microtubules pseudogene 3 \\
\hline GPX2 & 1.266532 & $1.24 \mathrm{E}-06$ & $3.98 \mathrm{E}-05$ & 4.848674 & Up & glutathione peroxidase 2 \\
\hline MRC1 & 1.265704 & 0.002608 & 0.020311 & 3.010482 & Up & mannose receptor C-type 1 \\
\hline SLC28A3 & 1.261081 & 0.005242 & 0.033569 & 2.791764 & Up & solute carrier family 28 member 3 \\
\hline GRINA & 1.260001 & $1.66 \mathrm{E}-09$ & $1.13 \mathrm{E}-07$ & 6.028311 & Up & glutamate ionotropic receptor NMDA type subunit associated protein 1 \\
\hline COMTD1 & 1.259376 & 0.000438 & 0.005062 & 3.516212 & Up & catechol-O-methyltransferase domain containing 1 \\
\hline ITPKC & 1.253391 & 0.003493 & 0.025012 & 2.92061 & Up & inositol-trisphosphate 3-kinase C \\
\hline LTBP3 & 1.251497 & $8.68 \mathrm{E}-07$ & $2.89 \mathrm{E}-05$ & 4.919326 & Up & latent transforming growth factor beta binding protein 3 \\
\hline MT1A & 1.250232 & 0.001512 & 0.013377 & 3.172284 & Up & metallothionein $1 \mathrm{~A}$ \\
\hline ZNF34 & 1.239207 & 0.001255 & 0.011605 & 3.226068 & Up & zinc finger protein 34 \\
\hline FBXW5 & 1.233028 & $1.30 \mathrm{E}-06$ & 4.11E-05 & 4.840395 & Up & F-box and WD repeat domain containing 5 \\
\hline LCN2 & 1.224204 & $1.29 \mathrm{E}-05$ & 0.00028 & 4.362318 & Up & lipocalin 2 \\
\hline CEACAM19 & 1.214525 & 0.007367 & 0.04329 & 2.679795 & Up & CEA cell adhesion molecule 19 \\
\hline PRLR & 1.214388 & 0.002876 & 0.021699 & 2.980724 & Up & prolactin receptor \\
\hline ZNF862 & 1.210155 & 0.003181 & 0.023371 & 2.949721 & Up & zinc finger protein 862 \\
\hline STXBP6 & 1.205294 & 0.000536 & 0.00594 & 3.462271 & Up & syntaxin binding protein 6 \\
\hline DUSP8 & 1.202609 & $8.43 \mathrm{E}-05$ & 0.001299 & 3.931698 & Up & dual specificity phosphatase 8 \\
\hline $\mathrm{ZC} 3 \mathrm{H} 12 \mathrm{~A}$ & 1.195651 & 0.001091 & 0.010383 & 3.265831 & Up & zinc finger $\mathrm{CCCH}$-type containing $12 \mathrm{~A}$ \\
\hline LHPP & 1.194241 & 0.003948 & 0.027329 & 2.882321 & Up & phospholysine phosphohistidine inorganic pyrophosphate phosphatase \\
\hline GP2 & 1.191415 & 0.002309 & 0.018474 & 3.047314 & Up & glycoprotein 2 \\
\hline
\end{tabular}




\begin{tabular}{|c|c|c|c|c|c|c|}
\hline SIK1 & 1.18886 & $1.21 \mathrm{E}-05$ & 0.000266 & 4.376562 & Up & salt inducible kinase 1 \\
\hline SERPING1 & 1.188811 & $1.08 \mathrm{E}-05$ & 0.00024 & 4.401319 & Up & serpin family $\mathrm{G}$ member 1 \\
\hline ATP13A2 & 1.188695 & 0.003061 & 0.022786 & 2.961525 & Up & ATPase cation transporting $13 \mathrm{~A} 2$ \\
\hline ADORA2A & 1.188079 & 0.002256 & 0.018136 & 3.054326 & Up & adenosine $\mathrm{A} 2 \mathrm{a}$ receptor \\
\hline BTG2 & 1.187414 & $2.04 \mathrm{E}-12$ & $2.70 \mathrm{E}-10$ & 7.031727 & Up & BTG anti-proliferation factor 2 \\
\hline SEMA3E & 1.184185 & $2.70 \mathrm{E}-05$ & 0.000518 & 4.197493 & Up & semaphorin $3 \mathrm{E}$ \\
\hline MUC13 & 1.181307 & $2.25 \mathrm{E}-07$ & 8.87E-06 & 5.177146 & Up & mucin 13 , cell surface associated \\
\hline STS & 1.181228 & 0.007185 & 0.042494 & 2.688133 & $\mathrm{Up}$ & steroid sulfatase \\
\hline CPM & 1.180739 & 0.000637 & 0.006829 & 3.415186 & Up & carboxypeptidase M \\
\hline PPP1R12B & 1.178311 & 0.00055 & 0.006085 & 3.45499 & Up & protein phosphatase 1 regulatory subunit $12 \mathrm{~B}$ \\
\hline TMEM30B & 1.174283 & $6.10 \mathrm{E}-08$ & $2.81 \mathrm{E}-06$ & 5.415896 & Up & transmembrane protein $30 \mathrm{~B}$ \\
\hline UNC119B & 1.172844 & 0.000104 & 0.00155 & 3.880943 & Up & unc-119 lipid binding chaperone B \\
\hline CHRNE & 1.172479 & 0.000127 & 0.001847 & 3.831284 & Up & cholinergic receptor nicotinic epsilon subunit \\
\hline RPS6KA6 & 1.170868 & 0.000293 & 0.003668 & 3.621693 & Up & ribosomal protein S6 kinase A6 \\
\hline ITGB3BP & 1.16542 & $2.55 \mathrm{E}-05$ & 0.000496 & 4.210131 & Up & integrin subunit beta 3 binding protein \\
\hline TPSG1 & 1.160373 & 0.001307 & 0.011969 & 3.214515 & Up & tryptase gamma 1 \\
\hline TNFAIP2 & 1.159342 & $3.35 \mathrm{E}-05$ & 0.000615 & 4.14848 & Up & TNF alpha induced protein 2 \\
\hline ZBTB7A & 1.155527 & $9.88 \mathrm{E}-10$ & 7.16E-08 & 6.111375 & Up & zinc finger and BTB domain containing 7A \\
\hline $\mathrm{BBC} 3$ & 1.154274 & 0.006236 & 0.03831 & 2.735096 & Up & BCL2 binding component 3 \\
\hline EPS8L2 & 1.149059 & $2.71 \mathrm{E}-06$ & $7.46 \mathrm{E}-05$ & 4.691359 & Up & EPS8 like 2 \\
\hline DAPK2 & 1.148499 & 0.00055 & 0.006084 & 3.455243 & Up & death associated protein kinase 2 \\
\hline SDC4 & 1.147833 & 2.13E-06 & $6.17 \mathrm{E}-05$ & 4.740494 & Up & syndecan 4 \\
\hline SPOCK3 & 1.147027 & 0.001613 & 0.013975 & 3.153535 & Up & SPARC (osteonectin), cwcv and kazal like domains proteoglycan 3 \\
\hline ZFP36 & 1.145497 & $4.76 \mathrm{E}-10$ & $3.82 \mathrm{E}-08$ & 6.226781 & Up & ZFP36 ring finger protein \\
\hline $\mathrm{CA} 2$ & 1.144512 & 0.003937 & 0.02728 & 2.883181 & Up & carbonic anhydrase 2 \\
\hline GRAMD4 & 1.143431 & 0.000704 & 0.007369 & 3.38796 & Up & GRAM domain containing 4 \\
\hline KIFC2 & 1.137498 & 0.006227 & 0.038275 & 2.735575 & Up & kinesin family member $\mathrm{C} 2$ \\
\hline RASSF5 & 1.136232 & $2.75 \mathrm{E}-06$ & $7.55 \mathrm{E}-05$ & 4.688523 & Up & Ras association domain family member 5 \\
\hline CTSD & 1.132154 & $3.47 \mathrm{E}-11$ & $3.60 \mathrm{E}-09$ & 6.625256 & Up & cathepsin D \\
\hline SPTSSB & 1.131418 & 0.000381 & 0.004523 & 3.553075 & Up & serine palmitoyltransferase small subunit B \\
\hline SOD2 & 1.126412 & $6.27 \mathrm{E}-11$ & $6.21 \mathrm{E}-09$ & 6.537195 & Up & superoxide dismutase 2 \\
\hline ROGDI & 1.125008 & 0.000108 & 0.001606 & 3.871842 & Up & rogdi atypical leucine zipper \\
\hline WHAMMP2 & 1.122241 & 0.001637 & 0.014145 & 3.149165 & Up & $\begin{array}{l}\text { WAS protein homolog associated with actin, golgi membranes and } \\
\text { microtubules pseudogene } 2\end{array}$ \\
\hline JAKMIP1 & 1.121972 & 0.007586 & 0.044265 & 2.669952 & Up & janus kinase and microtubule interacting protein 1 \\
\hline SMOC1 & 1.120388 & 4.12E-05 & 0.000724 & 4.100379 & Up & SPARC related modular calcium binding 1 \\
\hline KAT8 & 1.118592 & 0.000671 & 0.00712 & 3.401263 & Up & lysine acetyltransferase 8 \\
\hline MRS2P2 & 1.109493 & 0.005082 & 0.032798 & 2.801787 & Up & MRS2 pseudogene 2 \\
\hline $\mathrm{PBX} 2$ & 1.106311 & 0.000883 & 0.008875 & 3.325261 & Up & PBX homeobox 2 \\
\hline NAT9 & 1.105312 & 0.00236 & 0.018801 & 3.040739 & Up & $\mathrm{N}$-acetyltransferase 9 (putative) \\
\hline GBP2 & 1.097352 & 0.00316 & 0.023257 & 2.951688 & Up & guanylate binding protein 2 \\
\hline $\mathrm{APOH}$ & 1.0953 & 0.001207 & 0.01127 & 3.237117 & Up & apolipoprotein $\mathrm{H}$ \\
\hline ARSA & 1.094952 & $8.14 \mathrm{E}-05$ & 0.001267 & 3.940246 & Up & arylsulfatase A \\
\hline
\end{tabular}




\begin{tabular}{|c|c|c|c|c|c|c|}
\hline PIM3 & 1.093568 & $6.09 \mathrm{E}-05$ & 0.000997 & 4.009468 & Up & Pim-3 proto-oncogene, serine/threonine kinase \\
\hline DDX25 & 1.087549 & 0.008743 & 0.048956 & 2.621949 & Up & DEAD-box helicase 25 \\
\hline EGR3 & 1.083482 & 0.004081 & 0.02803 & 2.871842 & Up & early growth response 3 \\
\hline RAB17 & 1.080047 & 0.000476 & 0.00542 & 3.493738 & Up & RAB17, member RAS oncogene family \\
\hline SNORD102 & 1.078771 & 0.000943 & 0.009353 & 3.306857 & Up & small nucleolar RNA, C/D box 102 \\
\hline GSDMD & 1.07772 & 0.001234 & 0.011455 & 3.230845 & Up & gasdermin D \\
\hline HLA-B & 1.072221 & $2.50 \mathrm{E}-17$ & $6.18 \mathrm{E}-15$ & 8.467954 & Up & major histocompatibility complex, class I, B \\
\hline PON3 & 1.071857 & 0.00437 & 0.029495 & 2.850165 & Up & paraoxonase 3 \\
\hline $\mathrm{C} 1 \mathrm{R}$ & 1.071156 & 0.003238 & 0.023686 & 2.944197 & Up & complement $\mathrm{C} 1 \mathrm{r}$ \\
\hline HYI & 1.069764 & 4.05E-05 & 0.000713 & 4.104388 & Up & hydroxypyruvate isomerase (putative) \\
\hline DDX54 & 1.068929 & 0.001651 & 0.014228 & 3.146782 & Up & DEAD-box helicase 54 \\
\hline LONP1 & 1.066421 & $9.16 \mathrm{E}-06$ & 0.000211 & 4.436098 & Up & lon peptidase 1 , mitochondrial \\
\hline SERPINA1 & 1.062074 & $1.98 \mathrm{E}-08$ & $1.08 \mathrm{E}-06$ & 5.614097 & Up & serpin family A member 1 \\
\hline MGC70870 & 1.055503 & 0.004001 & 0.027598 & 2.878076 & Up & C-terminal binding protein 2 pseudogene \\
\hline UBD & 1.054856 & 0.007211 & 0.042594 & 2.686948 & Up & ubiquitin $\mathrm{D}$ \\
\hline CASZ1 & 1.054643 & 0.003332 & 0.024209 & 2.935302 & Up & castor zinc finger 1 \\
\hline SNCA & 1.052071 & 0.001465 & 0.013067 & 3.181438 & Up & synuclein alpha \\
\hline ONECUT2 & 1.050612 & 0.000491 & 0.005529 & 3.485354 & Up & one cut homeobox 2 \\
\hline EGR4 & 1.047477 & 0.003331 & 0.024209 & 2.935462 & Up & early growth response 4 \\
\hline PNLIP & 1.044398 & 0.001947 & 0.01625 & 3.098235 & Up & pancreatic lipase \\
\hline SLC29A4 & 1.044248 & $8.53 \mathrm{E}-05$ & 0.001311 & 3.928868 & Up & solute carrier family 29 member 4 \\
\hline JUN & 1.041042 & $5.35 \mathrm{E}-11$ & 5.37E-09 & 6.560931 & Up & Jun proto-oncogene, AP-1 transcription factor subunit \\
\hline OCRL & 1.035964 & 0.000137 & 0.001962 & 3.813522 & Up & OCRL inositol polyphosphate-5-phosphatase \\
\hline DHCR24 & 1.031289 & $3.93 \mathrm{E}-05$ & 0.000696 & 4.111443 & Up & 24-dehydrocholesterol reductase \\
\hline TMC5 & 1.028393 & 0.001332 & 0.012139 & 3.209069 & Up & transmembrane channel like 5 \\
\hline FSTL5 & 1.022268 & 0.000867 & 0.008745 & 3.330316 & Up & follistatin like 5 \\
\hline RAP1A & 1.013348 & $2.63 \mathrm{E}-06$ & $7.26 \mathrm{E}-05$ & 4.698065 & Up & RAP1A, member of RAS oncogene family \\
\hline AOX1 & 1.012166 & 0.002812 & 0.021393 & 2.987574 & $\mathrm{Up}$ & aldehyde oxidase 1 \\
\hline ZNF692 & 1.011426 & 0.002003 & 0.01662 & 3.089814 & Up & zinc finger protein 692 \\
\hline SLC22A17 & 1.011289 & $3.88 \mathrm{E}-07$ & $1.44 \mathrm{E}-05$ & 5.074865 & Up & solute carrier family 22 member 17 \\
\hline TRAPPC5 & 1.010652 & $5.56 \mathrm{E}-07$ & $1.94 \mathrm{E}-05$ & 5.005747 & Up & trafficking protein particle complex 5 \\
\hline CTSS & 1.010378 & 0.000557 & 0.006137 & 3.451709 & Up & cathepsin $\mathrm{S}$ \\
\hline COX5A & 1.008381 & $2.21 \mathrm{E}-11$ & 2.37E-09 & 6.691712 & Up & cytochrome c oxidase subunit $5 \mathrm{~A}$ \\
\hline NUDT16 & 1.004815 & 0.002233 & 0.01798 & 3.057404 & Up & nudix hydrolase 16 \\
\hline C1orf122 & 0.998501 & $1.80 \mathrm{E}-06$ & $5.45 \mathrm{E}-05$ & 4.774514 & Up & chromosome 1 open reading frame 122 \\
\hline SNHG1 & 0.992947 & 0.001731 & 0.014763 & 3.132913 & Up & small nucleolar RNA host gene 1 \\
\hline ABHD12 & 0.98966 & $4.40 \mathrm{E}-05$ & 0.000766 & 4.08564 & Up & abhydrolase domain containing 12 , lysophospholipase \\
\hline MIR147B & 0.989371 & $1.01 \mathrm{E}-06$ & $3.31 \mathrm{E}-05$ & 4.889678 & Up & microRNA $147 \mathrm{~b}$ \\
\hline TTR & 0.98906 & $2.80 \mathrm{E}-11$ & $2.95 \mathrm{E}-09$ & 6.656749 & Up & transthyretin \\
\hline RAB27A & 0.986412 & 0.000326 & 0.004015 & 3.593435 & Up & RAB27A, member RAS oncogene family \\
\hline GNAI1 & 0.98537 & $5.81 \mathrm{E}-07$ & $2.02 \mathrm{E}-05$ & 4.997344 & Up & G protein subunit alpha i1 \\
\hline TM4SF4 & 0.982872 & $1.68 \mathrm{E}-08$ & $9.37 \mathrm{E}-07$ & 5.642406 & Up & transmembrane $4 \mathrm{~L}$ six family member 4 \\
\hline $\mathrm{SCN} 3 \mathrm{~A}$ & 0.981372 & 0.001031 & 0.009986 & 3.281956 & Up & sodium voltage-gated channel alpha subunit 3 \\
\hline
\end{tabular}




\begin{tabular}{|c|c|c|c|c|c|c|}
\hline TMED10P1 & 0.981285 & 1.17E-09 & $8.18 \mathrm{E}-08$ & 6.084545 & Up & transmembrane p24 trafficking protein 10 pseudogene 1 \\
\hline SLC16A7 & 0.979185 & 0.003043 & 0.022676 & 2.963325 & Up & solute carrier family 16 member 7 \\
\hline IL6R & 0.97521 & 0.002568 & 0.020043 & 3.01516 & Up & interleukin 6 receptor \\
\hline IMPA2 & 0.974629 & 0.004064 & 0.027932 & 2.873126 & Up & inositol monophosphatase 2 \\
\hline DUSP1 & 0.97403 & $1.62 \mathrm{E}-09$ & $1.11 \mathrm{E}-07$ & 6.032277 & Up & dual specificity phosphatase 1 \\
\hline HSPA1B & 0.973353 & $1.57 \mathrm{E}-06$ & 4.84E-05 & 4.802269 & Up & heat shock protein family A (Hsp70) member 1B \\
\hline SLC12A7 & 0.970748 & 0.000457 & 0.005244 & 3.504999 & Up & solute carrier family 12 member 7 \\
\hline NAGLU & 0.967873 & 0.001187 & 0.011106 & 3.242006 & Up & $\mathrm{N}$-acetyl-alpha-glucosaminidase \\
\hline DLEC1 & 0.95751 & 0.001453 & 0.012998 & 3.183982 & Up & DLEC1 cilia and flagella associated protein \\
\hline C15orf48 & 0.957485 & $1.05 \mathrm{E}-07$ & 4.62E-06 & 5.317105 & Up & chromosome 15 open reading frame 48 \\
\hline $\mathrm{ABCB} 1$ & 0.951745 & 0.000274 & 0.003499 & 3.638721 & Up & ATP binding cassette subfamily B member 1 \\
\hline RIPPLY2 & 0.949701 & 0.003964 & 0.027394 & 2.880986 & Up & ripply transcriptional repressor 2 \\
\hline XAB2 & 0.947952 & 0.004995 & 0.032378 & 2.80736 & Up & XPA binding protein 2 \\
\hline PTP4A1 & 0.944972 & $3.71 \mathrm{E}-12$ & $4.71 \mathrm{E}-10$ & 6.947816 & Up & protein tyrosine phosphatase 4A1 \\
\hline GBA2 & 0.942585 & 0.000161 & 0.002251 & 3.774149 & Up & glucosylceramidase beta 2 \\
\hline $\mathrm{F} 10$ & 0.941789 & 0.000946 & 0.009363 & 3.305991 & Up & coagulation factor $\mathrm{X}$ \\
\hline ANG & 0.940414 & 0.000569 & 0.006246 & 3.445744 & Up & angiogenin \\
\hline AFMID & 0.940065 & 0.000663 & 0.007049 & 3.404575 & Up & arylformamidase \\
\hline ASL & 0.939426 & 0.000486 & 0.005494 & 3.488568 & Up & argininosuccinate lyase \\
\hline POLD3 & 0.937297 & 0.001543 & 0.013561 & 3.166421 & Up & DNA polymerase delta 3 , accessory subunit \\
\hline SERTAD3 & 0.932907 & 0.004437 & 0.029803 & 2.845289 & Up & SERTA domain containing 3 \\
\hline GABBR1 & 0.93278 & 0.008879 & 0.049473 & 2.616667 & Up & gamma-aminobutyric acid type B receptor subunit 1 \\
\hline CACNA1H & 0.924741 & 0.008616 & 0.048407 & 2.626944 & Up & calcium voltage-gated channel subunit alpha1 $\mathrm{H}$ \\
\hline SNORA16A & 0.923544 & 0.004705 & 0.031053 & 2.826564 & Up & small nucleolar RNA, H/ACA box 16A \\
\hline SCYL3 & 0.922277 & 0.006814 & 0.04082 & 2.705785 & Up & SCY 1 like pseudokinase 3 \\
\hline HLA-J & 0.918614 & $1.94 \mathrm{E}-12$ & $2.60 \mathrm{E}-10$ & 7.038739 & Up & major histocompatibility complex, class I, J (pseudogene) \\
\hline CXCL2 & 0.917487 & 0.007511 & 0.043967 & 2.673279 & Up & $\mathrm{C}-\mathrm{X}-\mathrm{C}$ motif chemokine ligand 2 \\
\hline PHF2 & 0.917134 & 0.000249 & 0.003226 & 3.663365 & Up & PHD finger protein 2 \\
\hline TRIB2 & 0.911615 & 0.003408 & 0.024577 & 2.928347 & Up & tribbles pseudokinase 2 \\
\hline PSMG1 & 0.909231 & 0.00298 & 0.022303 & 2.969825 & Up & proteasome assembly chaperone 1 \\
\hline PDK4 & 0.90829 & $4.21 \mathrm{E}-06$ & 0.000109 & 4.60061 & Up & pyruvate dehydrogenase kinase 4 \\
\hline SNORD58C & 0.907764 & 0.001022 & 0.009924 & 3.284462 & Up & small nucleolar RNA, C/D box $58 \mathrm{C}$ \\
\hline PDE4D & 0.906149 & 0.001133 & 0.010707 & 3.255316 & Up & phosphodiesterase $4 \mathrm{D}$ \\
\hline RPS10P7 & 0.90502 & 0.001134 & 0.010716 & 3.254896 & Up & ribosomal protein S10 pseudogene 7 \\
\hline CENPB & 0.904336 & 0.00031 & 0.003844 & 3.606946 & Up & centromere protein B \\
\hline HLA-E & 0.904162 & $6.68 \mathrm{E}-12$ & $8.06 \mathrm{E}-10$ & 6.864398 & Up & major histocompatibility complex, class I, E \\
\hline NUCB1 & 0.894836 & 8.94E-09 & $5.31 \mathrm{E}-07$ & 5.749746 & Up & nucleobindin 1 \\
\hline CHCHD10 & 0.894544 & 0.001878 & 0.015787 & 3.108808 & Up & coiled-coil-helix-coiled-coil-helix domain containing 10 \\
\hline PLA2G4C & 0.894513 & 0.005097 & 0.03286 & 2.800841 & Up & phospholipase A2 group IVC \\
\hline HLA-H & 0.894171 & $3.72 \mathrm{E}-16$ & $8.01 \mathrm{E}-14$ & 8.147234 & Up & major histocompatibility complex, class I, H (pseudogene) \\
\hline ALDH2 & 0.889919 & 0.000355 & 0.004306 & 3.571102 & Up & aldehyde dehydrogenase 2 family member \\
\hline TLCD1 & 0.889556 & 0.000423 & 0.004945 & 3.525304 & Up & TLC domain containing 1 \\
\hline QSOX1 & 0.889003 & 0.000201 & 0.002694 & 3.717941 & $\mathrm{Up}$ & quiescin sulfhydryl oxidase 1 \\
\hline
\end{tabular}




\begin{tabular}{|c|c|c|c|c|c|c|}
\hline GNPTG & 0.887892 & $1.68 \mathrm{E}-06$ & $5.13 \mathrm{E}-05$ & 4.788321 & Up & $\mathrm{N}$-acetylglucosamine-1-phosphate transferase subunit gamma \\
\hline GAMT & 0.885655 & 0.000914 & 0.009113 & 3.315622 & Up & guanidinoacetate $\mathrm{N}$-methyltransferase \\
\hline MUC20 & 0.885387 & 0.003114 & 0.023048 & 2.956302 & Up & mucin 20 , cell surface associated \\
\hline GAA & 0.883575 & 0.000625 & 0.006716 & 3.420709 & Up & glucosidase alpha, acid \\
\hline EPHX1 & 0.882556 & 0.001246 & 0.011542 & 3.228161 & $\mathrm{Up}$ & epoxide hydrolase 1 \\
\hline IRX2 & 0.87814 & 0.002012 & 0.016648 & 3.088401 & Up & iroquois homeobox 2 \\
\hline KDM1B & 0.877681 & 0.005787 & 0.036232 & 2.759592 & Up & lysine demethylase $1 \mathrm{~B}$ \\
\hline AGT & 0.872907 & 0.000369 & 0.00442 & 3.561241 & Up & angiotensinogen \\
\hline APOL1 & 0.871137 & 0.006065 & 0.037495 & 2.744251 & Up & apolipoprotein L1 \\
\hline ERBB3 & 0.866594 & 0.004566 & 0.030436 & 2.836126 & Up & erb-b2 receptor tyrosine kinase 3 \\
\hline GC & 0.865249 & 2.64E-05 & 0.000509 & 4.202422 & Up & GC vitamin D binding protein \\
\hline RMRP & 0.86397 & 0.007313 & 0.043044 & 2.682239 & Up & RNA component of mitochondrial RNA processing endoribonuclease \\
\hline PCSK1N & 0.863171 & $6.05 \mathrm{E}-08$ & $2.80 \mathrm{E}-06$ & 5.417249 & Up & proprotein convertase subtilisin/kexin type 1 inhibitor \\
\hline SLC38A4 & 0.862664 & $3.30 \mathrm{E}-05$ & 0.000608 & 4.151567 & Up & solute carrier family 38 member 4 \\
\hline MLXIPL & 0.858192 & $6.46 \mathrm{E}-05$ & 0.001051 & 3.995352 & Up & MLX interacting protein like \\
\hline RELA & 0.857395 & 0.001565 & 0.013703 & 3.162393 & Up & RELA proto-oncogene, NF-kB subunit \\
\hline ABHD14A & 0.850443 & 0.002904 & 0.02186 & 2.97768 & Up & abhydrolase domain containing $14 \mathrm{~A}$ \\
\hline C8orf82 & 0.850138 & 0.008439 & 0.047738 & 2.634 & Up & chromosome 8 open reading frame 82 \\
\hline UNKL & 0.847906 & 7.89E-06 & 0.000186 & 4.468256 & $\mathrm{Up}$ & unk like zinc finger \\
\hline PTPRN2 & 0.840172 & $6.24 \mathrm{E}-06$ & 0.000152 & 4.51796 & Up & protein tyrosine phosphatase receptor type $\mathrm{N} 2$ \\
\hline RTN1 & 0.837885 & 0.001814 & 0.015323 & 3.119108 & Up & reticulon 1 \\
\hline FAM193B & 0.835166 & 0.002056 & 0.016897 & 3.082015 & $\mathrm{Up}$ & family with sequence similarity 193 member B \\
\hline SLC44A4 & 0.830175 & 0.00423 & 0.028795 & 2.860443 & $\mathrm{Up}$ & solute carrier family 44 member 4 \\
\hline TMEM183B & 0.829275 & 0.000465 & 0.005319 & 3.500193 & Up & transmembrane protein 183B \\
\hline C4orf48 & 0.827987 & 0.000237 & 0.003105 & 3.676047 & Up & chromosome 4 open reading frame 48 \\
\hline TBL2 & 0.824308 & 0.006363 & 0.038834 & 2.72849 & Up & transducin beta like 2 \\
\hline CEBPD & 0.822274 & 0.001777 & 0.015066 & 3.125176 & Up & CCAAT enhancer binding protein delta \\
\hline RCAN2 & 0.817966 & 0.002449 & 0.019362 & 3.029615 & $\mathrm{Up}$ & regulator of calcineurin 2 \\
\hline LYZ & 0.814951 & 0.004806 & 0.031556 & 2.819766 & $\mathrm{Up}$ & lysozyme \\
\hline IFITM2 & 0.813561 & 0.000853 & 0.008613 & 3.335119 & Up & interferon induced transmembrane protein 2 \\
\hline FAM8A1 & 0.810943 & 0.004296 & 0.029143 & 2.855578 & $\mathrm{Up}$ & family with sequence similarity 8 member A1 \\
\hline REPIN1 & 0.808075 & 0.000433 & 0.005031 & 3.519312 & $\mathrm{Up}$ & replication initiator 1 \\
\hline DCAF11 & 0.805362 & 0.00197 & 0.016392 & 3.094725 & Up & DDB1 and CUL4 associated factor 11 \\
\hline HLA-C & 0.800301 & $3.33 \mathrm{E}-12$ & $4.26 \mathrm{E}-10$ & 6.962988 & Up & major histocompatibility complex, class I, C \\
\hline BTG1 & 0.800153 & $8.89 \mathrm{E}-09$ & $5.30 \mathrm{E}-07$ & 5.750679 & Up & BTG anti-proliferation factor 1 \\
\hline $\mathrm{RAB} 5 \mathrm{C}$ & 0.797754 & $1.87 \mathrm{E}-05$ & 0.000381 & 4.279496 & Up & RAB5C, member RAS oncogene family \\
\hline ARRDC4 & 0.79144 & 0.00267 & 0.02064 & 3.003382 & Up & arrestin domain containing 4 \\
\hline HLA-A & 0.789204 & $3.01 \mathrm{E}-15$ & $5.65 \mathrm{E}-13$ & 7.890626 & Up & major histocompatibility complex, class I, A \\
\hline PJA1 & 0.78577 & 0.007641 & 0.0445 & 2.667514 & Up & praja ring finger ubiquitin ligase 1 \\
\hline TRIOBP & 0.785496 & 0.004833 & 0.031656 & 2.817931 & Up & TRIO and F-actin binding protein \\
\hline CLU & 0.784071 & $1.52 \mathrm{E}-11$ & $1.70 \mathrm{E}-09$ & 6.745903 & Up & clusterin \\
\hline SDHA & 0.783467 & 0.000506 & 0.005656 & 3.477682 & Up & succinate dehydrogenase complex flavoprotein subunit A \\
\hline $\mathrm{KCNK} 3$ & 0.783131 & 0.000368 & 0.004415 & 3.561765 & Up & potassium two pore domain channel subfamily K member 3 \\
\hline
\end{tabular}




\begin{tabular}{|c|c|c|c|c|c|c|}
\hline RORA & 0.782585 & 0.002328 & 0.018607 & 3.044836 & Up & RAR related orphan receptor A \\
\hline GCG & 0.78151 & $1.87 \mathrm{E}-05$ & 0.000381 & 4.279675 & Up & glucagon \\
\hline SLC4A4 & 0.781078 & 0.003066 & 0.022802 & 2.961006 & Up & solute carrier family 4 member 4 \\
\hline SPINT2 & 0.780022 & $9.63 \mathrm{E}-11$ & $8.88 \mathrm{E}-09$ & 6.472653 & Up & serine peptidase inhibitor, Kunitz type 2 \\
\hline $\mathrm{CFC} 1$ & 0.776461 & 0.000113 & 0.001657 & 3.861527 & Up & cripto, FRL-1, cryptic family 1 \\
\hline $\mathrm{CFC1B}$ & 0.776461 & 0.000113 & 0.001657 & 3.861527 & Up & cripto, FRL-1, cryptic family $1 \mathrm{~B}$ \\
\hline GPX3 & 0.773677 & $9.26 \mathrm{E}-07$ & $3.06 \mathrm{E}-05$ & 4.906725 & Up & glutathione peroxidase 3 \\
\hline MAF & 0.769808 & 0.001577 & 0.013743 & 3.16013 & Up & MAF bZIP transcription factor \\
\hline PFKL & 0.768515 & 0.002023 & 0.016727 & 3.086839 & Up & phosphofructokinase, liver type \\
\hline BCS1L & 0.76814 & 0.00669 & 0.040207 & 2.71188 & Up & BCS1 homolog, ubiquinol-cytochrome c reductase complex chaperone \\
\hline POLR2A & 0.760606 & $3.80 \mathrm{E}-05$ & 0.000676 & 4.119563 & Up & RNA polymerase II subunit A \\
\hline RNF149 & 0.757628 & 3.03E-05 & 0.000569 & 4.171111 & Up & ring finger protein 149 \\
\hline HPS3 & 0.757014 & 0.003509 & 0.025028 & 2.919233 & Up & HPS3 biogenesis of lysosomal organelles complex 2 subunit 1 \\
\hline ANP32A & 0.756629 & $8.89 \mathrm{E}-05$ & 0.001361 & 3.919 & Up & acidic nuclear phosphoprotein 32 family member A \\
\hline COA5 & 0.755377 & 0.000444 & 0.005122 & 3.512514 & Up & cytochrome c oxidase assembly factor 5 \\
\hline PUS7L & 0.752571 & 0.004713 & 0.031065 & 2.826015 & Up & pseudouridine synthase 7 like \\
\hline DACH1 & 0.751247 & 0.001646 & 0.014201 & 3.147665 & Up & dachshund family transcription factor 1 \\
\hline RNPEP & 0.75053 & 0.000405 & 0.004758 & 3.536608 & Up & arginyl aminopeptidase \\
\hline SERPINE2 & 0.74936 & 0.001499 & 0.013289 & 3.174888 & Up & serpin family E member 2 \\
\hline LSM6 & 0.747747 & $5.05 \mathrm{E}-05$ & 0.00086 & 4.053353 & Up & LSM6 homolog, U6 small nuclear RNA and mRNA degradation associated \\
\hline ABLIM1 & 0.74695 & $3.75 \mathrm{E}-06$ & $9.89 \mathrm{E}-05$ & 4.624807 & Up & actin binding LIM protein 1 \\
\hline PPAN-P2RY11 & 0.745678 & $5.43 \mathrm{E}-05$ & 0.000913 & 4.036365 & Up & PPAN-P2RY11 readthrough \\
\hline GET4 & 0.743207 & 0.002683 & 0.020717 & 3.001928 & Up & guided entry of tail-anchored proteins factor 4 \\
\hline SPAG16 & 0.742949 & 0.000338 & 0.004142 & 3.584044 & Up & sperm associated antigen 16 \\
\hline RAP1GAP & 0.74019 & 0.001536 & 0.013537 & 3.167786 & Up & RAP1 GTPase activating protein \\
\hline MTMR12 & 0.739827 & 0.003094 & 0.022947 & 2.958222 & Up & myotubularin related protein 12 \\
\hline SNN & 0.739567 & 0.001212 & 0.011301 & 3.23615 & Up & stannin \\
\hline ITPK1 & 0.737421 & 0.002697 & 0.020771 & 3.000349 & Up & inositol-tetrakisphosphate 1-kinase \\
\hline PLTP & 0.735518 & $1.70 \mathrm{E}-07$ & $6.94 \mathrm{E}-06$ & 5.229404 & Up & phospholipid transfer protein \\
\hline SESN1 & 0.733841 & 0.004166 & 0.028469 & 2.865326 & Up & sestrin 1 \\
\hline CCDC86 & 0.732086 & 0.005585 & 0.035271 & 2.77121 & Up & coiled-coil domain containing 86 \\
\hline CHGB & 0.731999 & $5.33 \mathrm{E}-07$ & $1.87 \mathrm{E}-05$ & 5.014107 & Up & chromogranin B \\
\hline RGS4 & 0.731903 & $9.90 \mathrm{E}-05$ & 0.001492 & 3.892916 & Up & regulator of $\mathrm{G}$ protein signaling 4 \\
\hline CLDN7 & 0.729918 & $8.21 \mathrm{E}-05$ & 0.001277 & 3.938047 & Up & claudin 7 \\
\hline PPM1B & 0.724653 & 0.008246 & 0.047041 & 2.641841 & Up & protein phosphatase, $\mathrm{Mg} 2+/ \mathrm{Mn} 2+$ dependent $1 \mathrm{~B}$ \\
\hline C9orf16 & 0.722277 & 0.00032 & 0.00394 & 3.598756 & Up & chromosome 9 open reading frame 16 \\
\hline POLD2 & 0.72133 & 0.000506 & 0.005656 & 3.477682 & Up & DNA polymerase delta 2 , accessory subunit \\
\hline CYB5R3 & 0.720759 & $2.38 \mathrm{E}-06$ & $6.67 \mathrm{E}-05$ & 4.718096 & Up & cytochrome b5 reductase 3 \\
\hline TMEM176B & 0.720352 & $1.06 \mathrm{E}-05$ & 0.000237 & 4.40538 & Up & transmembrane protein 176B \\
\hline CMTM8 & 0.719692 & 0.008327 & 0.047336 & 2.638533 & Up & CKLF like MARVEL transmembrane domain containing 8 \\
\hline PCSK2 & 0.717848 & $1.24 \mathrm{E}-05$ & 0.000272 & 4.370337 & Up & proprotein convertase subtilisin/kexin type 2 \\
\hline P4HA1 & 0.717174 & 0.000198 & 0.002659 & 3.721805 & Up & prolyl 4-hydroxylase subunit alpha 1 \\
\hline RPRD1A & 0.71633 & 0.001345 & 0.012208 & 3.206219 & Up & regulation of nuclear pre-mRNA domain containing $1 \mathrm{~A}$ \\
\hline
\end{tabular}




\begin{tabular}{|c|c|c|c|c|c|c|}
\hline CES2 & 0.716072 & 0.001076 & 0.010276 & 3.269859 & Up & carboxylesterase 2 \\
\hline MAN1A1 & 0.714242 & $6.27 \mathrm{E}-06$ & 0.000152 & 4.516969 & Up & mannosidase alpha class $1 \mathrm{~A}$ member 1 \\
\hline CACNA1A & 0.712675 & 0.001542 & 0.013561 & 3.166569 & Up & calcium voltage-gated channel subunit alpha1 A \\
\hline KLHL12 & 0.711808 & 0.007545 & 0.044081 & 2.671774 & Up & kelch like family member 12 \\
\hline ID2 & 0.710358 & $3.60 \mathrm{E}-05$ & 0.000651 & 4.131867 & Up & inhibitor of DNA binding 2 \\
\hline ARHGAP12 & 0.709594 & 0.00071 & 0.007421 & 3.385629 & Up & Rho GTPase activating protein 12 \\
\hline MOCS2 & 0.709439 & $3.97 \mathrm{E}-05$ & 0.000701 & 4.109489 & Up & molybdenum cofactor synthesis 2 \\
\hline TUSC2 & 0.708041 & 0.006864 & 0.041019 & 2.703368 & Up & tumor suppressor 2, mitochondrial calcium regulator \\
\hline TCEAL2 & 0.707716 & 0.002121 & 0.017261 & 3.072677 & Up & transcription elongation factor A like 2 \\
\hline $\mathrm{U} 2 \mathrm{AF} 2$ & 0.70594 & 0.007189 & 0.042501 & 2.687943 & Up & U2 small nuclear RNA auxiliary factor 2 \\
\hline MGRN1 & 0.703772 & 0.00124 & 0.011491 & 3.22959 & Up & mahogunin ring finger 1 \\
\hline PPARA & 0.703065 & 0.005332 & 0.033986 & 2.786232 & Up & peroxisome proliferator activated receptor alpha \\
\hline CAPN7 & 0.701948 & 0.003625 & 0.025627 & 2.909118 & Up & calpain 7 \\
\hline ARL6IP4 & 0.700483 & $8.56 \mathrm{E}-05$ & 0.001313 & 3.928163 & Up & ADP ribosylation factor like GTPase 6 interacting protein 4 \\
\hline ANXA4 & 0.700394 & 0.00019 & 0.002576 & 3.732303 & Up & annexin $\mathrm{A} 4$ \\
\hline SUCLG2 & 0.70025 & 0.000827 & 0.008388 & 3.343483 & Up & succinate-CoA ligase GDP-forming subunit beta \\
\hline TFRC & 0.700148 & $6.66 \mathrm{E}-05$ & 0.001078 & 3.988234 & Up & transferrin receptor \\
\hline TTC39A & 0.699028 & 0.000609 & 0.006568 & 3.427548 & Up & tetratricopeptide repeat domain 39A \\
\hline MRPL38 & 0.695461 & 0.007369 & 0.04329 & 2.679669 & Up & mitochondrial ribosomal protein L38 \\
\hline TXNDC11 & 0.693311 & 0.002648 & 0.020521 & 3.005867 & Up & thioredoxin domain containing 11 \\
\hline SLC39A1 & 0.687707 & 0.003642 & 0.025729 & 2.907625 & Up & solute carrier family 39 member 1 \\
\hline LOC100129534 & 0.686772 & $3.72 \mathrm{E}-25$ & $1.67 \mathrm{E}-22$ & 10.36124 & Up & small nuclear ribonucleoprotein polypeptide $\mathrm{N}$ pseudogene \\
\hline COQ4 & 0.685338 & 0.006238 & 0.03831 & 2.735002 & Up & coenzyme Q4 \\
\hline GALNT3 & 0.684973 & 0.002196 & 0.017742 & 3.062363 & Up & polypeptide $\mathrm{N}$-acetylgalactosaminyltransferase 3 \\
\hline LDLR & 0.681819 & 0.000344 & 0.004196 & 3.579354 & Up & low density lipoprotein receptor \\
\hline BET1 & 0.681654 & 0.000455 & 0.005234 & 3.505722 & Up & Bet1 golgi vesicular membrane trafficking protein \\
\hline DUT & 0.67494 & 0.000365 & 0.004386 & 3.564089 & Up & deoxyuridine triphosphatase \\
\hline FTH1 & 0.674678 & $9.55 \mathrm{E}-12$ & 1.11E-09 & 6.813071 & Up & ferritin heavy chain 1 \\
\hline LY75-CD302 & 0.672266 & 0.00339 & 0.024517 & 2.930009 & Up & LY75-CD302 readthrough \\
\hline SSBP3 & 0.66799 & 0.005563 & 0.035169 & 2.772481 & Up & single stranded DNA binding protein 3 \\
\hline ARHGEF10L & 0.664155 & 0.008544 & 0.048154 & 2.629762 & Up & Rho guanine nucleotide exchange factor 10 like \\
\hline SLMAP & 0.663003 & 0.001703 & 0.014549 & 3.137686 & Up & sarcolemma associated protein \\
\hline PGRMC1 & 0.661335 & 0.000753 & 0.007766 & 3.36948 & Up & progesterone receptor membrane component 1 \\
\hline HLA-F & 0.659739 & $3.46 \mathrm{E}-05$ & 0.00063 & 4.140949 & Up & major histocompatibility complex, class I, F \\
\hline SEC24B & 0.658743 & 0.004881 & 0.031836 & 2.814813 & Up & SEC24 homolog B, COPII coat complex component \\
\hline PPP1CC & 0.652481 & 0.00073 & 0.007589 & 3.378032 & Up & protein phosphatase 1 catalytic subunit gamma \\
\hline $\mathrm{CCDC} 152$ & 0.651268 & 0.004007 & 0.027622 & 2.877578 & Up & coiled-coil domain containing 152 \\
\hline STAMBP & 0.648299 & 0.00318 & 0.023371 & 2.949738 & Up & STAM binding protein \\
\hline DPP7 & 0.644342 & 0.004665 & 0.030928 & 2.829281 & Up & dipeptidyl peptidase 7 \\
\hline CD81 & 0.644011 & $8.52 \mathrm{E}-06$ & 0.000199 & 4.451719 & Up & CD81 molecule \\
\hline AK1 & 0.64326 & 0.002527 & 0.019794 & 3.020081 & Up & adenylate kinase 1 \\
\hline SEMA4B & 0.642691 & 0.005039 & 0.032592 & 2.804522 & Up & semaphorin 4B \\
\hline HIF1A & 0.641721 & 5.37E-06 & 0.000134 & 4.54991 & Up & hypoxia inducible factor 1 subunit alpha \\
\hline
\end{tabular}




\begin{tabular}{|c|c|c|c|c|c|c|}
\hline GPAA1 & 0.640751 & 0.00177 & 0.015039 & 3.126294 & Up & glycosylphosphatidylinositol anchor attachment 1 \\
\hline SLC25A36 & 0.637235 & 0.002624 & 0.02039 & 3.008665 & Up & solute carrier family 25 member 36 \\
\hline CCDC18 & 0.635747 & 0.003935 & 0.027279 & 2.883347 & Up & coiled-coil domain containing 18 \\
\hline CPLX2 & 0.634062 & 0.006991 & 0.041576 & 2.697274 & Up & complexin 2 \\
\hline GGA2 & 0.633393 & 0.000806 & 0.008195 & 3.350871 & Up & golgi associated, gamma adaptin ear containing, ARF binding protein 2 \\
\hline GIGYF1 & 0.63099 & $1.35 \mathrm{E}-05$ & 0.000292 & 4.35222 & Up & GRB10 interacting GYF protein 1 \\
\hline SULT1E1 & -8.16887 & $1.02 \mathrm{E}-44$ & $1.17 \mathrm{E}-41$ & -14.0299 & Down & sulfotransferase family $1 \mathrm{E}$ member 1 \\
\hline SEMA3C & -6.99712 & $3.64 \mathrm{E}-53$ & $6.76 \mathrm{E}-50$ & -15.3482 & Down & semaphorin 3C \\
\hline ISLR & -6.99695 & $1.69 \mathrm{E}-65$ & $1.25 \mathrm{E}-61$ & -17.0924 & Down & immunoglobulin superfamily containing leucine rich repeat \\
\hline PCK1 & -6.8013 & $5.06 \mathrm{E}-39$ & $4.18 \mathrm{E}-36$ & -13.0673 & Down & phosphoenolpyruvate carboxykinase 1 \\
\hline KRT17 & -6.28089 & $3.08 \mathrm{E}-45$ & $3.81 \mathrm{E}-42$ & -14.1148 & Down & keratin 17 \\
\hline IGF2BP3 & -5.85349 & $6.87 \mathrm{E}-36$ & $5.10 \mathrm{E}-33$ & -12.5066 & Down & insulin like growth factor 2 mRNA binding protein 3 \\
\hline TDO2 & -5.56834 & $5.84 \mathrm{E}-33$ & $3.61 \mathrm{E}-30$ & -11.9588 & Down & tryptophan 2,3-dioxygenase \\
\hline POSTN & -5.43333 & $8.15 \mathrm{E}-47$ & $1.10 \mathrm{E}-43$ & -14.3686 & Down & periostin \\
\hline COL6A3 & -5.35601 & $6.96 \mathrm{E}-88$ & $1.03 \mathrm{E}-83$ & -19.8731 & Down & collagen type VI alpha 3 chain \\
\hline SOX11 & -5.00018 & $2.19 \mathrm{E}-33$ & $1.42 \mathrm{E}-30$ & -12.0398 & Down & SRY-box transcription factor 11 \\
\hline KRT6B & -4.96583 & $7.73 \mathrm{E}-12$ & $9.11 \mathrm{E}-10$ & -6.8434 & Down & keratin 6B \\
\hline IL1RL1 & -4.95954 & $1.75 \mathrm{E}-06$ & $5.29 \mathrm{E}-05$ & -4.78075 & Down & interleukin 1 receptor like 1 \\
\hline $\mathrm{BNC} 2$ & -4.91463 & $1.36 \mathrm{E}-28$ & $6.73 \mathrm{E}-26$ & -11.0928 & Down & basonuclin 2 \\
\hline SLCO2A1 & -4.86935 & $2.68 \mathrm{E}-17$ & $6.53 \mathrm{E}-15$ & -8.4597 & Down & solute carrier organic anion transporter family member $2 \mathrm{~A} 1$ \\
\hline TAGLN & -4.73723 & $1.06 \mathrm{E}-38$ & $8.25 \mathrm{E}-36$ & -13.0113 & Down & transgelin \\
\hline S1PR1 & -4.72945 & $9.65 \mathrm{E}-10$ & 7.03E-08 & -6.11507 & Down & sphingosine-1-phosphate receptor 1 \\
\hline NRG3 & -4.7291 & $6.74 \mathrm{E}-08$ & 3.07E-06 & -5.39788 & Down & neuregulin 3 \\
\hline GJC1 & -4.70503 & $2.40 \mathrm{E}-30$ & $1.32 \mathrm{E}-27$ & -11.4482 & Down & gap junction protein gamma 1 \\
\hline NTM & -4.63089 & $3.87 \mathrm{E}-18$ & $1.06 \mathrm{E}-15$ & -8.68256 & Down & neurotrimin \\
\hline ST6GAL2 & -4.60433 & $2.92 \mathrm{E}-15$ & $5.55 \mathrm{E}-13$ & -7.89441 & Down & ST6 beta-galactoside alpha-2,6-sialyltransferase 2 \\
\hline CSF2 & -4.59632 & $1.14 \mathrm{E}-11$ & $1.31 \mathrm{E}-09$ & -6.78722 & Down & colony stimulating factor 2 \\
\hline SULF1 & -4.52079 & $1.82 \mathrm{E}-42$ & $1.93 \mathrm{E}-39$ & -13.6575 & Down & sulfatase 1 \\
\hline CD34 & -4.493 & $1.30 \mathrm{E}-14$ & $2.33 \mathrm{E}-12$ & -7.70548 & Down & CD34 molecule \\
\hline RASSF2 & -4.42796 & $1.18 \mathrm{E}-13$ & $1.85 \mathrm{E}-11$ & -7.41871 & Down & Ras association domain family member 2 \\
\hline ACTA2 & -4.36581 & 4.29E-39 & $3.74 \mathrm{E}-36$ & -13.08 & Down & actin alpha 2, smooth muscle \\
\hline TOP2A & -4.363 & 4.09E-12 & $5.15 \mathrm{E}-10$ & -6.9339 & Down & DNA topoisomerase II alpha \\
\hline CENPE & -4.35643 & 4.63E-08 & $2.25 \mathrm{E}-06$ & -5.46505 & Down & centromere protein $\mathrm{E}$ \\
\hline ESM1 & -4.33455 & $7.61 \mathrm{E}-10$ & $5.68 \mathrm{E}-08$ & -6.15282 & Down & endothelial cell specific molecule 1 \\
\hline ADAMTS12 & -4.31989 & $6.88 \mathrm{E}-17$ & $1.57 \mathrm{E}-14$ & -8.34908 & Down & ADAM metallopeptidase with thrombospondin type 1 motif 12 \\
\hline TGFBI & -4.31696 & $6.45 \mathrm{E}-49$ & $9.58 \mathrm{E}-46$ & -14.7 & Down & transforming growth factor beta induced \\
\hline OLFML1 & -4.29731 & $2.09 \mathrm{E}-10$ & $1.79 \mathrm{E}-08$ & -6.35473 & Down & olfactomedin like 1 \\
\hline GJA4 & -4.28558 & $1.78 \mathrm{E}-05$ & 0.000365 & -4.29121 & Down & gap junction protein alpha 4 \\
\hline CLIC5 & -4.25197 & 1.80E-08 & 9.94E-07 & -5.63015 & Down & chloride intracellular channel 5 \\
\hline OLFML3 & -4.24213 & $2.40 \mathrm{E}-13$ & $3.59 \mathrm{E}-11$ & -7.32459 & Down & olfactomedin like 3 \\
\hline COL3A1 & -4.19955 & $1.49 \mathrm{E}-54$ & $3.70 \mathrm{E}-51$ & -15.554 & Down & collagen type III alpha 1 chain \\
\hline EGF & -4.18772 & $1.09 \mathrm{E}-12$ & $1.50 \mathrm{E}-10$ & -7.11819 & Down & epidermal growth factor \\
\hline MUC4 & -4.18467 & $5.87 \mathrm{E}-06$ & 0.000144 & -4.53109 & Down & mucin 4 , cell surface associated \\
\hline
\end{tabular}




\begin{tabular}{|c|c|c|c|c|c|c|}
\hline COL1A2 & -4.17512 & $1.54 \mathrm{E}-55$ & $4.59 \mathrm{E}-52$ & -15.6987 & Down & collagen type I alpha 2 chain \\
\hline FN1 & -4.17427 & $8.36 \mathrm{E}-63$ & 4.14E-59 & -16.7268 & Down & fibronectin 1 \\
\hline LUM & -4.1577 & $1.94 \mathrm{E}-40$ & $1.80 \mathrm{E}-37$ & -13.313 & Down & lumican \\
\hline SPARC & -4.14871 & $5.75 \mathrm{E}-57$ & $2.13 \mathrm{E}-53$ & -15.9061 & Down & secreted protein acidic and cysteine rich \\
\hline FRZB & -4.1365 & $8.96 \mathrm{E}-10$ & $6.58 \mathrm{E}-08$ & -6.12698 & Down & frizzled related protein \\
\hline COL5A1 & -4.12837 & $1.48 \mathrm{E}-28$ & $6.93 \mathrm{E}-26$ & -11.0849 & Down & collagen type $\mathrm{V}$ alpha 1 chain \\
\hline THY1 & -4.09014 & $8.03 \mathrm{E}-25$ & $3.51 \mathrm{E}-22$ & -10.2874 & Down & Thy- 1 cell surface antigen \\
\hline EMCN & -4.0853 & $8.78 \mathrm{E}-11$ & 8.34E-09 & -6.48654 & Down & endomucin \\
\hline PECAM1 & -4.06447 & $4.57 \mathrm{E}-13$ & $6.79 \mathrm{E}-11$ & -7.23754 & Down & platelet and endothelial cell adhesion molecule 1 \\
\hline GAP43 & -4.00349 & $6.11 \mathrm{E}-19$ & $1.85 \mathrm{E}-16$ & -8.88993 & Down & growth associated protein 43 \\
\hline ASB9 & -3.99904 & $6.65 \mathrm{E}-29$ & $3.40 \mathrm{E}-26$ & -11.1566 & Down & ankyrin repeat and SOCS box containing 9 \\
\hline AFAP1L1 & -3.99574 & $1.57 \mathrm{E}-07$ & $6.51 \mathrm{E}-06$ & -5.24426 & Down & actin filament associated protein 1 like 1 \\
\hline XAF1 & -3.96621 & $7.76 \mathrm{E}-15$ & $1.44 \mathrm{E}-12$ & -7.77142 & Down & XIAP associated factor 1 \\
\hline SRPX & -3.9576 & $8.61 \mathrm{E}-10$ & $6.36 \mathrm{E}-08$ & -6.13322 & Down & sushi repeat containing protein $\mathrm{X}$-linked \\
\hline HEPH & -3.94057 & $1.14 \mathrm{E}-08$ & $6.66 \mathrm{E}-07$ & -5.70859 & Down & hephaestin \\
\hline BCAS1 & -3.91979 & $2.94 \mathrm{E}-06$ & $7.98 \mathrm{E}-05$ & -4.67529 & Down & brain enriched myelin associated protein 1 \\
\hline NES & -3.90754 & $1.59 \mathrm{E}-15$ & $3.14 \mathrm{E}-13$ & -7.96988 & Down & nestin \\
\hline FABP4 & -3.90568 & 4.07E-11 & 4.17E-09 & -6.60142 & Down & fatty acid binding protein 4 \\
\hline CST6 & -3.89561 & $1.18 \mathrm{E}-07$ & $5.03 \mathrm{E}-06$ & -5.29674 & Down & cystatin E/M \\
\hline $\mathrm{CD} 248$ & -3.88898 & $5.14 \mathrm{E}-12$ & $6.34 \mathrm{E}-10$ & -6.90153 & Down & CD248 molecule \\
\hline PTGS2 & -3.86934 & $2.65 \mathrm{E}-19$ & $8.51 \mathrm{E}-17$ & -8.9824 & Down & prostaglandin-endoperoxide synthase 2 \\
\hline ENPEP & -3.85123 & $1.95 \mathrm{E}-06$ & $5.75 \mathrm{E}-05$ & -4.7584 & Down & glutamyl aminopeptidase \\
\hline LTB4R & -3.84992 & $6.75 \mathrm{E}-07$ & $2.30 \mathrm{E}-05$ & -4.96848 & Down & leukotriene B4 receptor \\
\hline ITGA11 & -3.8315 & $2.63 \mathrm{E}-10$ & $2.22 \mathrm{E}-08$ & -6.31901 & Down & integrin subunit alpha 11 \\
\hline IGDCC4 & -3.82989 & $6.78 \mathrm{E}-17$ & $1.57 \mathrm{E}-14$ & -8.35083 & Down & immunoglobulin superfamily DCC subclass member 4 \\
\hline SPOCD1 & -3.82989 & 4.20E-08 & $2.08 \mathrm{E}-06$ & -5.48232 & Down & SPOC domain containing 1 \\
\hline VCAN & -3.82926 & $1.49 \mathrm{E}-28$ & $6.93 \mathrm{E}-26$ & -11.0844 & Down & versican \\
\hline MFAP2 & -3.82601 & $2.21 \mathrm{E}-20$ & 7.63E-18 & -9.25168 & Down & microfibril associated protein 2 \\
\hline PI15 & -3.81639 & $1.29 \mathrm{E}-11$ & $1.45 \mathrm{E}-09$ & -6.76976 & Down & peptidase inhibitor 15 \\
\hline COL1A1 & -3.81542 & 2.97E-50 & $4.90 \mathrm{E}-47$ & -14.907 & Down & collagen type I alpha 1 chain \\
\hline HHATL & -3.81056 & $2.62 \mathrm{E}-08$ & $1.38 \mathrm{E}-06$ & -5.56493 & Down & hedgehog acyltransferase like \\
\hline LRRC17 & -3.78527 & $1.35 \mathrm{E}-09$ & $9.35 \mathrm{E}-08$ & -6.06157 & Down & leucine rich repeat containing 17 \\
\hline FHOD3 & -3.77153 & $5.30 \mathrm{E}-12$ & $6.45 \mathrm{E}-10$ & -6.89726 & Down & formin homology 2 domain containing 3 \\
\hline DACT1 & -3.75494 & $1.10 \mathrm{E}-10$ & 9.99E-09 & -6.45208 & Down & dishevelled binding antagonist of beta catenin 1 \\
\hline PIEZO2 & -3.73731 & $1.53 \mathrm{E}-15$ & $3.07 \mathrm{E}-13$ & -7.97465 & Down & piezo type mechanosensitive ion channel component 2 \\
\hline REP15 & -3.72234 & $2.11 \mathrm{E}-07$ & $8.40 \mathrm{E}-06$ & -5.18894 & Down & RAB 15 effector protein \\
\hline CPA4 & -3.69821 & $2.45 \mathrm{E}-12$ & $3.19 \mathrm{E}-10$ & -7.00608 & Down & carboxypeptidase A4 \\
\hline NID1 & -3.67312 & $1.68 \mathrm{E}-18$ & 4.79E-16 & -8.77708 & Down & nidogen 1 \\
\hline PRSS12 & -3.65724 & $1.30 \mathrm{E}-15$ & $2.64 \mathrm{E}-13$ & -7.9947 & Down & serine protease 12 \\
\hline GUCY1A2 & -3.64287 & $3.48 \mathrm{E}-05$ & 0.000633 & -4.13939 & Down & guanylate cyclase 1 soluble subunit alpha 2 \\
\hline HAS2 & -3.61739 & $5.44 \mathrm{E}-21$ & $2.07 \mathrm{E}-18$ & -9.40026 & Down & hyaluronan synthase 2 \\
\hline TMEM233 & -3.61228 & 0.001142 & 0.010766 & -3.25303 & Down & transmembrane protein 233 \\
\hline ADA & -3.60883 & $2.18 \mathrm{E}-13$ & $3.31 \mathrm{E}-11$ & -7.33707 & Down & adenosine deaminase \\
\hline
\end{tabular}




\begin{tabular}{|c|c|c|c|c|c|c|}
\hline LDHAL6A & -3.60004 & $5.92 \mathrm{E}-06$ & 0.000145 & -4.5294 & Down & lactate dehydrogenase $\mathrm{A}$ like $6 \mathrm{~A}$ \\
\hline PALMD & -3.59649 & $7.10 \mathrm{E}-08$ & $3.23 \mathrm{E}-06$ & -5.38855 & Down & palmdelphin \\
\hline FIBIN & -3.57473 & $5.38 \mathrm{E}-08$ & $2.57 \mathrm{E}-06$ & -5.43815 & Down & fin bud initiation factor homolog \\
\hline ARG1 & -3.57404 & 0.005807 & 0.036311 & -2.75847 & Down & arginase 1 \\
\hline CDH13 & -3.56691 & $3.89 \mathrm{E}-05$ & 0.000691 & -4.11376 & Down & cadherin 13 \\
\hline CDH11 & -3.48989 & $8.32 \mathrm{E}-21$ & $3.01 \mathrm{E}-18$ & -9.35553 & Down & cadherin 11 \\
\hline BMP4 & -3.48514 & 2.37E-08 & $1.26 \mathrm{E}-06$ & -5.58236 & Down & bone morphogenetic protein 4 \\
\hline HCLS1 & -3.48103 & $6.80 \mathrm{E}-07$ & $2.31 \mathrm{E}-05$ & -4.96694 & Down & hematopoietic cell-specific Lyn substrate 1 \\
\hline HSF2BP & -3.4663 & 0.002364 & 0.01882 & -3.0402 & Down & heat shock transcription factor 2 binding protein \\
\hline $\mathrm{KIF} 2 \mathrm{C}$ & -3.46461 & 0.00019 & 0.002576 & -3.73201 & Down & kinesin family member $2 \mathrm{C}$ \\
\hline CMAHP & -3.4563 & 0.000365 & 0.004386 & -3.56411 & Down & cytidine monophospho-N-acetylneuraminic acid hydroxylase, pseudogene \\
\hline CCNJL & -3.44621 & $3.38 \mathrm{E}-05$ & 0.00062 & -4.14601 & Down & cyclin J like \\
\hline COL12A1 & -3.43746 & $6.71 \mathrm{E}-13$ & $9.40 \mathrm{E}-11$ & -7.18524 & Down & collagen type XII alpha 1 chain \\
\hline PLXDC1 & -3.42606 & $6.77 \mathrm{E}-09$ & 4.17E-07 & -5.79652 & Down & plexin domain containing 1 \\
\hline FLI1 & -3.42332 & 0.000294 & 0.003672 & -3.62093 & Down & Fli-1 proto-oncogene, ETS transcription factor \\
\hline SLC2A2 & -3.42142 & $1.23 \mathrm{E}-08$ & 7.10E-07 & -5.6957 & Down & solute carrier family 2 member 2 \\
\hline MEG8 & -3.41669 & $1.00 \mathrm{E}-05$ & 0.000226 & -4.41685 & Down & maternally expressed 8 , small nucleolar RNA host gene \\
\hline FLNC & -3.41112 & 0.000175 & 0.002423 & -3.75208 & Down & filamin C \\
\hline ALPK2 & -3.40152 & 0.00075 & 0.007745 & -3.37063 & Down & alpha kinase 2 \\
\hline SST & -3.37446 & $1.81 \mathrm{E}-53$ & $3.83 \mathrm{E}-50$ & -15.3936 & Down & somatostatin \\
\hline BTN2A2 & -3.36353 & $3.62 \mathrm{E}-11$ & $3.73 \mathrm{E}-09$ & -6.61885 & Down & butyrophilin subfamily 2 member A2 \\
\hline CYBRD1 & -3.35493 & $6.77 \mathrm{E}-12$ & $8.11 \mathrm{E}-10$ & -6.86235 & Down & cytochrome $b$ reductase 1 \\
\hline BUB1 & -3.35131 & 0.00012 & 0.001749 & -3.84637 & Down & BUB1 mitotic checkpoint serine/threonine kinase \\
\hline STRA6 & -3.35023 & $1.39 \mathrm{E}-07$ & $5.85 \mathrm{E}-06$ & -5.2665 & Down & signaling receptor and transporter of retinol STRA6 \\
\hline PTHLH & -3.34655 & $1.42 \mathrm{E}-08$ & 8.09E-07 & -5.67072 & Down & parathyroid hormone like hormone \\
\hline TULP2 & -3.33857 & $4.38 \mathrm{E}-10$ & $3.55 \mathrm{E}-08$ & -6.24001 & Down & TUB like protein 2 \\
\hline LEF1 & -3.33571 & $6.25 \mathrm{E}-07$ & $2.16 \mathrm{E}-05$ & -4.98345 & Down & lymphoid enhancer binding factor 1 \\
\hline GLI2 & -3.32111 & $9.92 \mathrm{E}-07$ & $3.26 \mathrm{E}-05$ & -4.89315 & Down & GLI family zinc finger 2 \\
\hline POU2F2 & -3.31154 & $2.21 \mathrm{E}-06$ & $6.35 \mathrm{E}-05$ & -4.73306 & Down & POU class 2 homeobox 2 \\
\hline ZFHX4 & -3.30289 & $6.86 \mathrm{E}-11$ & $6.70 \mathrm{E}-09$ & -6.52373 & Down & zinc finger homeobox 4 \\
\hline VGLL3 & -3.29299 & $5.04 \mathrm{E}-16$ & $1.07 \mathrm{E}-13$ & -8.11063 & Down & vestigial like family member 3 \\
\hline ADAMTS6 & -3.27426 & $7.88 \mathrm{E}-16$ & $1.65 \mathrm{E}-13$ & -8.05597 & Down & ADAM metallopeptidase with thrombospondin type 1 motif 6 \\
\hline SRPX2 & -3.27082 & $8.78 \mathrm{E}-20$ & $2.90 \mathrm{E}-17$ & -9.10308 & Down & sushi repeat containing protein $\mathrm{X}$-linked 2 \\
\hline TNFAIP6 & -3.27015 & $1.41 \mathrm{E}-23$ & $5.97 \mathrm{E}-21$ & -10.0079 & Down & TNF alpha induced protein 6 \\
\hline UPK1B & -3.26379 & $2.81 \mathrm{E}-06$ & 7.70E-05 & -4.68427 & Down & uroplakin 1B \\
\hline DDX43 & -3.26053 & 0.000486 & 0.005496 & -3.4881 & Down & DEAD-box helicase 43 \\
\hline P4HA3 & -3.25419 & $2.56 \mathrm{E}-05$ & 0.000497 & -4.20961 & Down & prolyl 4-hydroxylase subunit alpha 3 \\
\hline ADAM28 & -3.25015 & $1.68 \mathrm{E}-05$ & 0.000349 & -4.30313 & Down & ADAM metallopeptidase domain 28 \\
\hline RPA4 & -3.23437 & 0.002467 & 0.019475 & -3.02739 & Down & replication protein $\mathrm{A} 4$ \\
\hline GIMAP7 & -3.23156 & 0.000937 & 0.009301 & -3.30879 & Down & GTPase, IMAP family member 7 \\
\hline COL22A1 & -3.23086 & 0.001317 & 0.012041 & -3.21229 & Down & collagen type XXII alpha 1 chain \\
\hline BGN & -3.22635 & $1.70 \mathrm{E}-23$ & $7.02 \mathrm{E}-21$ & -9.98901 & Down & biglycan \\
\hline BPIFC & -3.21015 & 0.006092 & 0.037603 & -2.74277 & Down & BPI fold containing family $\mathrm{C}$ \\
\hline
\end{tabular}




\begin{tabular}{|c|c|c|c|c|c|c|}
\hline IL18 & -3.20589 & $8.09 \mathrm{E}-11$ & $7.80 \mathrm{E}-09$ & -6.49886 & Down & interleukin 18 \\
\hline GPC3 & -3.20357 & $5.22 \mathrm{E}-06$ & 0.000131 & -4.55581 & Down & glypican 3 \\
\hline CD93 & -3.19308 & 5.91E-08 & $2.76 \mathrm{E}-06$ & -5.42147 & Down & CD93 molecule \\
\hline PGF & -3.19231 & $1.25 \mathrm{E}-05$ & 0.000273 & -4.36831 & Down & placental growth factor \\
\hline PLEKHG1 & -3.18607 & 4.24E-10 & $3.48 \mathrm{E}-08$ & -6.24488 & Down & pleckstrin homology and RhoGEF domain containing G1 \\
\hline CMTM3 & -3.18497 & $5.80 \mathrm{E}-20$ & $1.96 \mathrm{E}-17$ & -9.14799 & Down & CKLF like MARVEL transmembrane domain containing 3 \\
\hline CTSK & -3.16971 & $1.64 \mathrm{E}-17$ & 4.35E-15 & -8.51671 & Down & cathepsin $\mathrm{K}$ \\
\hline GRIP1 & -3.16616 & $6.42 \mathrm{E}-10$ & 4.89E-08 & -6.17974 & Down & glutamate receptor interacting protein 1 \\
\hline S1PR3 & -3.16211 & $6.70 \mathrm{E}-10$ & 5.07E-08 & -6.17307 & Down & sphingosine-1-phosphate receptor 3 \\
\hline CNGA3 & -3.15833 & 4.78E-10 & 3.82E-08 & -6.22618 & Down & cyclic nucleotide gated channel subunit alpha 3 \\
\hline ADAMTS16 & -3.15294 & $1.09 \mathrm{E}-05$ & 0.000243 & -4.39764 & Down & ADAM metallopeptidase with thrombospondin type 1 motif 16 \\
\hline LAMA1 & -3.15139 & $1.14 \mathrm{E}-05$ & 0.000253 & -4.38889 & Down & laminin subunit alpha 1 \\
\hline $\mathrm{A} 2 \mathrm{M}$ & -3.14799 & $2.96 \mathrm{E}-17$ & $7.09 \mathrm{E}-15$ & -8.44816 & Down & alpha-2-macroglobulin \\
\hline MYCT1 & -3.12838 & 2.80E-05 & 0.000535 & -4.18913 & Down & MYC target 1 \\
\hline LRRC70 & -3.12174 & $3.67 \mathrm{E}-05$ & 0.000657 & -4.12742 & Down & leucine rich repeat containing 70 \\
\hline ST8SIA4 & -3.12163 & 2.25E-08 & $1.21 \mathrm{E}-06$ & -5.59122 & Down & ST8 alpha-N-acetyl-neuraminide alpha-2,8-sialyltransferase 4 \\
\hline COL5A2 & -3.11416 & $1.22 \mathrm{E}-20$ & $4.31 \mathrm{E}-18$ & -9.31513 & Down & collagen type $\mathrm{V}$ alpha 2 chain \\
\hline DGKI & -3.10767 & $1.70 \mathrm{E}-05$ & 0.000352 & -4.30088 & Down & diacylglycerol kinase iota \\
\hline NETO2 & -3.10713 & 7.23E-05 & 0.00115 & -3.96847 & Down & neuropilin and tolloid like 2 \\
\hline SNAI2 & -3.09547 & $2.95 \mathrm{E}-11$ & 3.08E-09 & -6.64921 & Down & snail family transcriptional repressor 2 \\
\hline UNC5D & -3.09533 & $5.19 \mathrm{E}-10$ & $4.08 \mathrm{E}-08$ & -6.21334 & Down & unc-5 netrin receptor $\mathrm{D}$ \\
\hline TRIM36 & -3.09527 & 0.000179 & 0.002459 & -3.74687 & Down & tripartite motif containing 36 \\
\hline COL14A1 & -3.09404 & $4.86 \mathrm{E}-05$ & 0.000836 & -4.06217 & Down & collagen type XIV alpha 1 chain \\
\hline EBF1 & -3.06903 & $5.45 \mathrm{E}-13$ & 7.94E-11 & -7.21355 & Down & EBF transcription factor 1 \\
\hline VAT1L & -3.06878 & $1.32 \mathrm{E}-09$ & $9.21 \mathrm{E}-08$ & -6.0648 & Down & vesicle amine transport 1 like \\
\hline EPHB6 & -3.06128 & $6.62 \mathrm{E}-07$ & 2.27E-05 & -4.97217 & Down & EPH receptor B6 \\
\hline ALK & -3.05586 & $2.28 \mathrm{E}-06$ & $6.49 \mathrm{E}-05$ & -4.72653 & Down & ALK receptor tyrosine kinase \\
\hline GHRL & -3.05351 & $1.65 \mathrm{E}-11$ & $1.81 \mathrm{E}-09$ & -6.73366 & Down & ghrelin and obestatin prepropeptide \\
\hline HEY2 & -3.04581 & 0.001033 & 0.009991 & -3.28144 & Down & hes related family bHLH transcription factor with YRPW motif 2 \\
\hline FBN1 & -3.04283 & $2.19 \mathrm{E}-16$ & $4.85 \mathrm{E}-14$ & -8.21132 & Down & fibrillin 1 \\
\hline SLC7A5 & -3.0307 & $3.65 \mathrm{E}-16$ & 7.97E-14 & -8.14962 & Down & solute carrier family 7 member 5 \\
\hline RASIP1 & -3.0253 & $1.38 \mathrm{E}-05$ & 0.000297 & -4.34762 & Down & Ras interacting protein 1 \\
\hline CDK1 & -3.01086 & 0.001964 & 0.016358 & -3.09569 & Down & cyclin dependent kinase 1 \\
\hline C1orf54 & -3.00335 & $1.08 \mathrm{E}-09$ & $7.70 \mathrm{E}-08$ & -6.09648 & Down & chromosome 1 open reading frame 54 \\
\hline SLC9A9 & -2.99945 & 3.67E-07 & $1.37 \mathrm{E}-05$ & -5.08539 & Down & solute carrier family 9 member A9 \\
\hline SOX7 & -2.99541 & 3.92E-05 & 0.000694 & -4.1124 & Down & SRY-box transcription factor 7 \\
\hline TET1 & -2.98965 & $2.86 \mathrm{E}-09$ & $1.88 \mathrm{E}-07$ & -5.93916 & Down & tet methylcytosine dioxygenase 1 \\
\hline TMPRSS11E & -2.97933 & 0.002569 & 0.020043 & -3.01511 & Down & transmembrane serine protease $11 \mathrm{E}$ \\
\hline MGP & -2.97256 & $1.24 \mathrm{E}-14$ & $2.27 \mathrm{E}-12$ & -7.71206 & Down & matrix Gla protein \\
\hline RAB38 & -2.97255 & 0.002875 & 0.021699 & -2.98083 & Down & RAB38, member RAS oncogene family \\
\hline HOXA3 & -2.9662 & $1.47 \mathrm{E}-05$ & 0.00031 & -4.33381 & Down & homeobox A3 \\
\hline $\mathrm{F} 2 \mathrm{R}$ & -2.96073 & $1.37 \mathrm{E}-13$ & $2.12 \mathrm{E}-11$ & -7.3993 & Down & coagulation factor II thrombin receptor \\
\hline GGT5 & -2.95488 & $1.87 \mathrm{E}-06$ & $5.57 \mathrm{E}-05$ & -4.7675 & Down & gamma-glutamyltransferase 5 \\
\hline
\end{tabular}




\begin{tabular}{|c|c|c|c|c|c|c|}
\hline ANO1 & -2.94931 & 3.19E-07 & $1.21 \mathrm{E}-05$ & -5.11161 & Down & $\operatorname{anoctamin} 1$ \\
\hline TPX2 & -2.94516 & 0.000244 & 0.003179 & -3.66887 & Down & TPX2 microtubule nucleation factor \\
\hline $\mathrm{KCNH} 7$ & -2.94502 & $2.84 \mathrm{E}-05$ & 0.00054 & -4.1863 & Down & potassium voltage-gated channel subfamily $\mathrm{H}$ member 7 \\
\hline ECSCR & -2.93745 & 0.000713 & 0.007436 & -3.38472 & Down & endothelial cell surface expressed chemotaxis and apoptosis regulator \\
\hline SALL4 & -2.92459 & $1.19 \mathrm{E}-06$ & $3.84 \mathrm{E}-05$ & -4.85668 & Down & spalt like transcription factor 4 \\
\hline EDNRA & -2.92262 & $6.19 \mathrm{E}-10$ & $4.76 \mathrm{E}-08$ & -6.18556 & Down & endothelin receptor type A \\
\hline LTBP2 & -2.91196 & $4.94 \mathrm{E}-13$ & $7.26 \mathrm{E}-11$ & -7.22705 & Down & latent transforming growth factor beta binding protein 2 \\
\hline DLL4 & -2.91058 & 2.82E-14 & $4.77 \mathrm{E}-12$ & -7.6061 & Down & delta like canonical Notch ligand 4 \\
\hline MMP3 & -2.90798 & $2.23 \mathrm{E}-06$ & $6.38 \mathrm{E}-05$ & -4.73179 & Down & matrix metallopeptidase 3 \\
\hline TBC1D2 & -2.8974 & 0.000753 & 0.007766 & -3.36966 & Down & TBC1 domain family member 2 \\
\hline AGPAT4-IT1 & -2.89031 & $2.87 \mathrm{E}-05$ & 0.000544 & -4.18382 & Down & AGPAT4 intronic transcript 1 \\
\hline KIT & -2.89029 & $1.92 \mathrm{E}-06$ & $5.69 \mathrm{E}-05$ & -4.76181 & Down & KIT proto-oncogene, receptor tyrosine kinase \\
\hline ECM2 & -2.8828 & $6.75 \mathrm{E}-05$ & 0.00109 & -3.98476 & Down & extracellular matrix protein 2 \\
\hline KANK4 & -2.88067 & $2.26 \mathrm{E}-08$ & $1.21 \mathrm{E}-06$ & -5.59113 & Down & KN motif and ankyrin repeat domains 4 \\
\hline GLIPR1L2 & -2.87857 & $6.40 \mathrm{E}-05$ & 0.001042 & -3.99754 & Down & GLIPR1 like 2 \\
\hline PLA2R1 & -2.87806 & 0.001 & 0.009746 & -3.29066 & Down & phospholipase A2 receptor 1 \\
\hline FAT3 & -2.87436 & $5.46 \mathrm{E}-05$ & 0.000915 & -4.03496 & Down & FAT atypical cadherin 3 \\
\hline CLEC4A & -2.87294 & 5.63E-08 & $2.65 \mathrm{E}-06$ & -5.43021 & Down & C-type lectin domain family 4 member A \\
\hline ARHGAP25 & -2.86511 & 0.001001 & 0.009757 & -3.29016 & Down & Rho GTPase activating protein 25 \\
\hline SLC17A6 & -2.86505 & $1.70 \mathrm{E}-09$ & $1.16 \mathrm{E}-07$ & -6.02454 & Down & solute carrier family 17 member 6 \\
\hline PCDH12 & -2.85982 & 0.001587 & 0.013797 & -3.15831 & Down & protocadherin 12 \\
\hline NELL2 & -2.8545 & 8.54E-06 & 0.000199 & -4.45114 & Down & neural EGFL like 2 \\
\hline ITM2A & -2.84768 & $2.86 \mathrm{E}-05$ & 0.000544 & -4.18436 & Down & integral membrane protein $2 \mathrm{~A}$ \\
\hline NID2 & -2.84571 & $1.32 \mathrm{E}-18$ & $3.84 \mathrm{E}-16$ & -8.80424 & Down & nidogen 2 \\
\hline SPATA9 & -2.84139 & 0.00542 & 0.034441 & -2.78094 & Down & spermatogenesis associated 9 \\
\hline SGCD & -2.84061 & $8.87 \mathrm{E}-11$ & $8.34 \mathrm{E}-09$ & -6.48501 & Down & sarcoglycan delta \\
\hline LFNG & -2.83599 & $1.25 \mathrm{E}-07$ & $5.31 \mathrm{E}-06$ & -5.28574 & Down & LFNG O-fucosylpeptide 3-beta-N-acetylglucosaminyltransferase \\
\hline HLA-DQB1 & -2.83038 & 2.70E-06 & 7.45E-05 & -4.69216 & Down & major histocompatibility complex, class II, DQ beta 1 \\
\hline MMRN2 & -2.8234 & 0.000835 & 0.008454 & -3.34107 & Down & multimerin 2 \\
\hline ZNF792 & -2.81878 & 0.002122 & 0.017261 & -3.07254 & Down & zinc finger protein 792 \\
\hline ZBTB47 & -2.81672 & $8.84 \mathrm{E}-11$ & $8.34 \mathrm{E}-09$ & -6.48554 & Down & zinc finger and BTB domain containing 47 \\
\hline SHF & -2.81445 & 0.001202 & 0.011223 & -3.2385 & Down & Src homology 2 domain containing $F$ \\
\hline STOX2 & -2.81284 & 2.67E-07 & $1.04 \mathrm{E}-05$ & -5.14502 & Down & storkhead box 2 \\
\hline HRH1 & -2.80952 & 0.001428 & 0.012824 & -3.18885 & Down & histamine receptor $\mathrm{H} 1$ \\
\hline KIF6 & -2.80909 & 0.00234 & 0.018683 & -3.04329 & Down & kinesin family member 6 \\
\hline TMSB15A & -2.80489 & 0.003508 & 0.025028 & -2.91935 & Down & thymosin beta $15 \mathrm{~A}$ \\
\hline TIMP3 & -2.8038 & 4.86E-29 & $2.58 \mathrm{E}-26$ & -11.1845 & Down & TIMP metallopeptidase inhibitor 3 \\
\hline ECM1 & -2.79117 & $5.29 \mathrm{E}-09$ & $3.33 \mathrm{E}-07$ & -5.83785 & Down & extracellular matrix protein 1 \\
\hline EFNB2 & -2.78262 & $3.18 \mathrm{E}-10$ & $2.64 \mathrm{E}-08$ & -6.28971 & Down & ephrin B2 \\
\hline GSTM1 & -2.78072 & $1.01 \mathrm{E}-09$ & 7.27E-08 & -6.10804 & Down & glutathione S-transferase mu 1 \\
\hline PCDH18 & -2.7784 & $1.12 \mathrm{E}-07$ & 4.83E-06 & -5.30644 & Down & protocadherin 18 \\
\hline NEXN & -2.77765 & $1.09 \mathrm{E}-12$ & $1.50 \mathrm{E}-10$ & -7.11905 & Down & nexilin F-actin binding protein \\
\hline L1TD1 & -2.77685 & 0.005073 & 0.032755 & -2.80235 & Down & LINE1 type transposase domain containing 1 \\
\hline
\end{tabular}




\begin{tabular}{|c|c|c|c|c|c|c|}
\hline SV2B & -2.77498 & $1.79 \mathrm{E}-07$ & 7.22E-06 & -5.21948 & Down & synaptic vesicle glycoprotein $2 \mathrm{~B}$ \\
\hline SOX18 & -2.76804 & 0.006074 & 0.037528 & -2.74375 & Down & SRY-box transcription factor 18 \\
\hline MXRA8 & -2.76766 & $5.24 \mathrm{E}-07$ & $1.85 \mathrm{E}-05$ & -5.01738 & Down & matrix remodeling associated 8 \\
\hline LRRC8E & -2.7564 & 0.000417 & 0.004875 & -3.52935 & Down & leucine rich repeat containing 8 VRAC subunit $\mathrm{E}$ \\
\hline MME & -2.7491 & 0.000693 & 0.007326 & -3.39227 & Down & membrane metalloendopeptidase \\
\hline ADORA2B & -2.74876 & $5.74 \mathrm{E}-05$ & 0.000957 & -4.02315 & Down & adenosine $\mathrm{A} 2 \mathrm{~b}$ receptor \\
\hline SYNGR3 & -2.7427 & 0.000291 & 0.003655 & -3.62343 & Down & synaptogyrin 3 \\
\hline LAMA4 & -2.74251 & $2.56 \mathrm{E}-14$ & 4.37E-12 & -7.61889 & Down & laminin subunit alpha 4 \\
\hline TAF4B & -2.73821 & 0.000393 & 0.004653 & -3.545 & Down & TATA-box binding protein associated factor $4 \mathrm{~b}$ \\
\hline THBS1 & -2.73673 & $7.95 \mathrm{E}-21$ & $2.95 \mathrm{E}-18$ & -9.36034 & Down & thrombospondin 1 \\
\hline SERPIND1 & -2.73469 & 0.004266 & 0.028995 & -2.85777 & Down & serpin family $\mathrm{D}$ member 1 \\
\hline IL16 & -2.72384 & $3.78 \mathrm{E}-06$ & $9.95 \mathrm{E}-05$ & -4.62289 & Down & interleukin 16 \\
\hline CDKN3 & -2.72285 & 0.004623 & 0.030704 & -2.83218 & Down & cyclin dependent kinase inhibitor 3 \\
\hline SYNPO2 & -2.7177 & 0.000514 & 0.005736 & -3.47327 & Down & synaptopodin 2 \\
\hline ECEL1 & -2.71388 & $6.05 \mathrm{E}-06$ & 0.000147 & -4.52456 & Down & endothelin converting enzyme like 1 \\
\hline PDGFB & -2.69036 & 5.23E-07 & $1.85 \mathrm{E}-05$ & -5.01779 & Down & platelet derived growth factor subunit B \\
\hline UBE2C & -2.68901 & 0.002195 & 0.017742 & -3.06256 & Down & ubiquitin conjugating enzyme $\mathrm{E} 2 \mathrm{C}$ \\
\hline HCST & -2.68161 & 0.000187 & 0.002549 & -3.7358 & Down & hematopoietic cell signal transducer \\
\hline TMEM150C & -2.67938 & 4.09E-08 & $2.04 \mathrm{E}-06$ & -5.48704 & Down & transmembrane protein $150 \mathrm{C}$ \\
\hline OLFML2B & -2.66936 & $3.75 \mathrm{E}-05$ & 0.000671 & -4.12246 & Down & olfactomedin like $2 \mathrm{~B}$ \\
\hline COLQ & -2.66494 & $2.65 \mathrm{E}-05$ & 0.000511 & -4.20122 & Down & collagen like tail subunit of asymmetric acetylcholinesterase \\
\hline STIL & -2.66382 & 0.000424 & 0.004948 & -3.52458 & Down & STIL centriolar assembly protein \\
\hline MCM6 & -2.66171 & $6.57 \mathrm{E}-08$ & $3.00 \mathrm{E}-06$ & -5.40261 & Down & minichromosome maintenance complex component 6 \\
\hline BEND6 & -2.65803 & 0.00165 & 0.014228 & -3.14695 & Down & BEN domain containing 6 \\
\hline PXDN & -2.65789 & $1.77 \mathrm{E}-17$ & $4.61 \mathrm{E}-15$ & -8.50802 & Down & peroxidasin \\
\hline RIPK3 & -2.65386 & 9.93E-06 & 0.000224 & -4.41867 & Down & receptor interacting serine/threonine kinase 3 \\
\hline ASPM & -2.65337 & 0.005797 & 0.036279 & -2.75903 & Down & assembly factor for spindle microtubules \\
\hline GHRLOS & -2.64408 & 2.47E-07 & $9.68 \mathrm{E}-06$ & -5.15983 & Down & ghrelin opposite strand/antisense RNA \\
\hline MSRB3 & -2.6411 & $3.65 \mathrm{E}-08$ & $1.85 \mathrm{E}-06$ & -5.50705 & Down & methionine sulfoxide reductase B3 \\
\hline HMGA2 & -2.64083 & 0.000876 & 0.008816 & -3.32752 & Down & high mobility group AT-hook 2 \\
\hline TRIM45 & -2.63708 & $1.20 \mathrm{E}-08$ & $6.99 \mathrm{E}-07$ & -5.69971 & Down & tripartite motif containing 45 \\
\hline ATP6V1E2 & -2.63692 & 0.003308 & 0.024094 & -2.93754 & Down & ATPase $\mathrm{H}+$ transporting $\mathrm{V} 1$ subunit $\mathrm{E} 2$ \\
\hline SIX2 & -2.63471 & $7.28 \mathrm{E}-05$ & 0.001155 & -3.96686 & Down & SIX homeobox 2 \\
\hline ABI3BP & -2.63028 & $6.04 \mathrm{E}-10$ & 4.67E-08 & -6.18938 & Down & ABI family member 3 binding protein \\
\hline GDPD5 & -2.6276 & $1.02 \mathrm{E}-05$ & 0.000231 & -4.41198 & Down & glycerophosphodiester phosphodiesterase domain containing 5 \\
\hline PGM2 & -2.62683 & $1.85 \mathrm{E}-12$ & $2.50 \mathrm{E}-10$ & -7.04523 & Down & phosphoglucomutase 2 \\
\hline INHBE & -2.62503 & 0.004887 & 0.031838 & -2.81439 & Down & inhibin subunit beta $\mathrm{E}$ \\
\hline SLC1A3 & -2.62355 & 0.005447 & 0.03458 & -2.77934 & Down & solute carrier family 1 member 3 \\
\hline GLRA1 & -2.62355 & 4.43E-06 & 0.000113 & -4.59034 & Down & glycine receptor alpha 1 \\
\hline WNT5B & -2.62164 & 0.001625 & 0.014049 & -3.15143 & Down & Wnt family member $5 \mathrm{~B}$ \\
\hline PTN & -2.61945 & 0.002944 & 0.022103 & -2.97351 & Down & pleiotrophin \\
\hline ZNF221 & -2.61559 & 0.000133 & 0.001914 & -3.82135 & Down & zinc finger protein 221 \\
\hline SNX30 & -2.60435 & $3.60 \mathrm{E}-14$ & $5.88 \mathrm{E}-12$ & -7.57466 & Down & sorting nexin family member 30 \\
\hline
\end{tabular}




\begin{tabular}{|c|c|c|c|c|c|c|}
\hline LRRC2 & -2.60302 & 0.001772 & 0.015046 & -3.12599 & Down & leucine rich repeat containing 2 \\
\hline SLC16A10 & -2.59549 & 0.001137 & 0.010732 & -3.25427 & Down & solute carrier family 16 member 10 \\
\hline $\mathrm{E} 2 \mathrm{~F} 7$ & -2.59406 & 0.003671 & 0.025888 & -2.90509 & Down & E2F transcription factor 7 \\
\hline COL15A1 & -2.58589 & $1.77 \mathrm{E}-13$ & $2.71 \mathrm{E}-11$ & -7.36502 & Down & collagen type XV alpha 1 chain \\
\hline CECR2 & -2.57882 & 0.001106 & 0.010498 & -3.26199 & Down & CECR2 histone acetyl-lysine reader \\
\hline GAL & -2.5777 & $1.81 \mathrm{E}-05$ & 0.00037 & -4.28761 & Down & galanin and GMAP prepropeptide \\
\hline RSPH9 & -2.57587 & 7.46E-06 & 0.000176 & -4.48025 & Down & radial spoke head component 9 \\
\hline GREM2 & -2.57338 & 0.001316 & 0.012041 & -3.21236 & Down & gremlin 2, DAN family BMP antagonist \\
\hline ULBP1 & -2.56108 & 8.10E-06 & 0.00019 & -4.46259 & Down & UL16 binding protein 1 \\
\hline ADAMTS2 & -2.55522 & $2.83 \mathrm{E}-10$ & 2.37E-08 & -6.30783 & Down & ADAM metallopeptidase with thrombospondin type 1 motif 2 \\
\hline TNFRSF11B & -2.55422 & $1.05 \mathrm{E}-15$ & $2.16 \mathrm{E}-13$ & -8.02144 & Down & TNF receptor superfamily member $11 \mathrm{~b}$ \\
\hline PDGFRA & -2.55277 & $1.38 \mathrm{E}-06$ & 4.33E-05 & -4.82788 & Down & platelet derived growth factor receptor alpha \\
\hline ANKRD1 & -2.55247 & $1.64 \mathrm{E}-06$ & $5.02 \mathrm{E}-05$ & -4.79397 & Down & ankyrin repeat domain 1 \\
\hline ZSCAN5A & -2.5507 & 0.000186 & 0.002532 & -3.73795 & Down & zinc finger and SCAN domain containing $5 \mathrm{~A}$ \\
\hline ANLN & -2.54686 & 0.00894 & 0.049674 & -2.61436 & Down & anillin actin binding protein \\
\hline CALCRL & -2.5459 & 6.67E-05 & 0.001078 & -3.98793 & Down & calcitonin receptor like receptor \\
\hline PTCHD1 & -2.53207 & 0.008784 & 0.049131 & -2.62035 & Down & patched domain containing 1 \\
\hline COL5A3 & -2.53127 & 4.02E-05 & 0.000709 & -4.10631 & Down & collagen type $\mathrm{V}$ alpha 3 chain \\
\hline TUBB2B & -2.52603 & $1.88 \mathrm{E}-15$ & $3.66 \mathrm{E}-13$ & -7.94933 & Down & tubulin beta $2 \mathrm{~B}$ class IIb \\
\hline CDH5 & -2.5235 & 0.000309 & 0.003837 & -3.60762 & Down & cadherin 5 \\
\hline LOX & -2.5188 & $2.50 \mathrm{E}-07$ & $9.77 \mathrm{E}-06$ & -5.15766 & Down & lysyl oxidase \\
\hline COL4A1 & -2.51738 & $4.87 \mathrm{E}-17$ & $1.15 \mathrm{E}-14$ & -8.38969 & Down & collagen type IV alpha 1 chain \\
\hline ARHGEF10 & -2.51681 & $6.61 \mathrm{E}-06$ & 0.000159 & -4.50591 & Down & Rho guanine nucleotide exchange factor 10 \\
\hline MFGE8 & -2.51447 & $1.59 \mathrm{E}-07$ & $6.58 \mathrm{E}-06$ & -5.24136 & Down & milk fat globule EGF and factor V/VIII domain containing \\
\hline AEBP1 & -2.50754 & $4.36 \mathrm{E}-10$ & $3.55 \mathrm{E}-08$ & -6.2407 & Down & AE binding protein 1 \\
\hline TRIM9 & -2.50587 & $6.64 \mathrm{E}-11$ & $6.53 \mathrm{E}-09$ & -6.52855 & Down & tripartite motif containing 9 \\
\hline ZNF300 & -2.50558 & 4.35E-06 & 0.000112 & -4.59401 & Down & zinc finger protein 300 \\
\hline ERG & -2.50536 & 0.000161 & 0.002256 & -3.77336 & Down & ETS transcription factor ERG \\
\hline SLC22A3 & -2.5052 & 0.000534 & 0.005923 & -3.46328 & Down & solute carrier family 22 member 3 \\
\hline FRMD5 & -2.50177 & 0.001268 & 0.011698 & -3.22323 & Down & FERM domain containing 5 \\
\hline GLIPR2 & -2.50019 & $2.91 \mathrm{E}-14$ & $4.85 \mathrm{E}-12$ & -7.60241 & Down & GLI pathogenesis related 2 \\
\hline PADI2 & -2.49886 & 0.002365 & 0.01882 & -3.04012 & Down & peptidyl arginine deiminase 2 \\
\hline TK1 & -2.49497 & 8.31E-05 & 0.001288 & -3.93535 & Down & thymidine kinase 1 \\
\hline DCAF4L1 & -2.4942 & 0.000198 & 0.002659 & -3.72214 & Down & DDB1 and CUL4 associated factor 4 like 1 \\
\hline CNTNAP2 & -2.49282 & 0.005935 & 0.036859 & -2.75137 & Down & contactin associated protein 2 \\
\hline TNFAIP8L1 & -2.49185 & 2.31E-06 & $6.52 \mathrm{E}-05$ & -4.72453 & Down & TNF alpha induced protein 8 like 1 \\
\hline $\mathrm{ZC} 4 \mathrm{H} 2$ & -2.49002 & 7.59E-08 & $3.42 \mathrm{E}-06$ & -5.37653 & Down & zinc finger $\mathrm{C} 4 \mathrm{H} 2$-type containing \\
\hline ANKRD7 & -2.48969 & 0.000358 & 0.004334 & -3.56895 & Down & ankyrin repeat domain 7 \\
\hline ZKSCAN3 & -2.48914 & 0.000748 & 0.007729 & -3.37138 & Down & zinc finger with KRAB and SCAN domains 3 \\
\hline MMP9 & -2.48823 & $2.21 \mathrm{E}-05$ & 0.000438 & -4.24242 & Down & matrix metallopeptidase 9 \\
\hline PGAM2 & -2.48601 & 0.002059 & 0.016911 & -3.08159 & Down & phosphoglycerate mutase 2 \\
\hline FFAR2 & -2.4797 & 0.000571 & 0.00625 & -3.44516 & Down & free fatty acid receptor 2 \\
\hline CDR1 & -2.47829 & $2.58 \mathrm{E}-06$ & 7.17E-05 & -4.70155 & Down & cerebellar degeneration related protein 1 \\
\hline
\end{tabular}




\begin{tabular}{|c|c|c|c|c|c|c|}
\hline KLHL25 & -2.47258 & 0.000631 & 0.006766 & -3.41812 & Down & kelch like family member 25 \\
\hline ZNF16 & -2.47235 & $4.04 \mathrm{E}-06$ & 0.000105 & -4.60933 & Down & zinc finger protein 16 \\
\hline TCF7 & -2.4718 & 2.01E-08 & $1.08 \mathrm{E}-06$ & -5.61122 & Down & transcription factor 7 \\
\hline MMS22L & -2.47167 & $1.14 \mathrm{E}-08$ & $6.66 \mathrm{E}-07$ & -5.70884 & Down & MMS22 like, DNA repair protein \\
\hline PHLDA1 & -2.46355 & 4.09E-19 & $1.27 \mathrm{E}-16$ & -8.93438 & Down & pleckstrin homology like domain family A member 1 \\
\hline SULT4A1 & -2.46335 & $1.73 \mathrm{E}-07$ & 7.04E-06 & -5.2257 & Down & sulfotransferase family $4 \mathrm{~A}$ member 1 \\
\hline GTDC1 & -2.46248 & $1.90 \mathrm{E}-06$ & $5.65 \mathrm{E}-05$ & -4.76341 & Down & glycosyltransferase like domain containing 1 \\
\hline PCDH7 & -2.46229 & 7.44E-12 & $8.84 \mathrm{E}-10$ & -6.84888 & Down & protocadherin 7 \\
\hline COL6A2 & -2.45951 & $1.34 \mathrm{E}-06$ & $4.22 \mathrm{E}-05$ & -4.83439 & Down & collagen type VI alpha 2 chain \\
\hline HSD3BP4 & -2.45746 & 0.000403 & 0.004737 & -3.53824 & Down & hydroxy-delta-5-steroid dehydrogenase, 3 beta, pseudogene 4 \\
\hline KDR & -2.45267 & $9.46 \mathrm{E}-05$ & 0.001435 & -3.90403 & Down & kinase insert domain receptor \\
\hline MYL9 & -2.45098 & $5.12 \mathrm{E}-10$ & 4.04E-08 & -6.21545 & Down & myosin light chain 9 \\
\hline NRBP2 & -2.44931 & $5.08 \mathrm{E}-07$ & $1.81 \mathrm{E}-05$ & -5.02323 & Down & nuclear receptor binding protein 2 \\
\hline SERPINE1 & -2.44289 & $2.10 \mathrm{E}-17$ & $5.38 \mathrm{E}-15$ & -8.48813 & Down & serpin family $\mathrm{E}$ member 1 \\
\hline CDH6 & -2.4343 & $1.27 \mathrm{E}-08$ & $7.31 \mathrm{E}-07$ & -5.6895 & Down & cadherin 6 \\
\hline DCHS1 & -2.43327 & $5.12 \mathrm{E}-07$ & $1.82 \mathrm{E}-05$ & -5.02175 & Down & dachsous cadherin-related 1 \\
\hline KIF26B & -2.43288 & $4.55 \mathrm{E}-05$ & 0.000788 & -4.0775 & Down & kinesin family member 26B \\
\hline ZRANB3 & -2.42846 & $3.91 \mathrm{E}-07$ & $1.44 \mathrm{E}-05$ & -5.07349 & Down & zinc finger RANBP2-type containing 3 \\
\hline GPR161 & -2.42658 & $3.29 \mathrm{E}-05$ & 0.000606 & -4.15258 & Down & G protein-coupled receptor 161 \\
\hline NTNG2 & -2.42597 & $2.30 \mathrm{E}-07$ & $9.03 \mathrm{E}-06$ & -5.17351 & Down & netrin G2 \\
\hline ACOX2 & -2.42189 & 0.003694 & 0.025973 & -2.90319 & Down & acyl-CoA oxidase 2 \\
\hline RASSF9 & -2.41937 & 0.002996 & 0.022378 & -2.96817 & Down & Ras association domain family member 9 \\
\hline AKNA & -2.41806 & $2.82 \mathrm{E}-06$ & 7.71E-05 & -4.68362 & Down & AT-hook transcription factor \\
\hline ESAM & -2.40768 & 7.39E-05 & 0.001167 & -3.96338 & Down & endothelial cell adhesion molecule \\
\hline FBN2 & -2.40672 & 0.008006 & 0.046061 & -2.65183 & Down & fibrillin 2 \\
\hline C19orf33 & -2.40386 & $4.52 \mathrm{E}-07$ & $1.64 \mathrm{E}-05$ & -5.04584 & Down & chromosome 19 open reading frame 33 \\
\hline LOC644656 & -2.40278 & 0.002798 & 0.021326 & -2.98915 & Down & uncharacterized LOC644656 \\
\hline PCDHB5 & -2.40027 & 0.000313 & 0.003872 & -3.60443 & Down & protocadherin beta 5 \\
\hline GHR & -2.39572 & 0.006329 & 0.038709 & -2.73023 & Down & growth hormone receptor \\
\hline IGSF9 & -2.39305 & 0.000112 & 0.001649 & -3.86333 & Down & immunoglobulin superfamily member 9 \\
\hline CDC6 & -2.3927 & 0.000947 & 0.009363 & -3.30573 & Down & cell division cycle 6 \\
\hline ZSCAN20 & -2.38179 & $4.74 \mathrm{E}-05$ & 0.000817 & -4.06812 & Down & zinc finger and SCAN domain containing 20 \\
\hline TRPA1 & -2.37958 & $3.39 \mathrm{E}-06$ & $9.08 \mathrm{E}-05$ & -4.6454 & Down & transient receptor potential cation channel subfamily A member 1 \\
\hline CERS4 & -2.37699 & 3.01E-07 & $1.15 \mathrm{E}-05$ & -5.12261 & Down & ceramide synthase 4 \\
\hline RGS5 & -2.37518 & $4.56 \mathrm{E}-07$ & $1.65 \mathrm{E}-05$ & -5.04413 & Down & regulator of G protein signaling 5 \\
\hline MFAP4 & -2.37381 & $2.11 \mathrm{E}-09$ & $1.40 \mathrm{E}-07$ & -5.98924 & Down & microfibril associated protein 4 \\
\hline SNTB1 & -2.37108 & $1.28 \mathrm{E}-05$ & 0.000279 & -4.36296 & Down & syntrophin beta 1 \\
\hline TGFB3 & -2.37062 & $1.28 \mathrm{E}-10$ & $1.15 \mathrm{E}-08$ & -6.42986 & Down & transforming growth factor beta 3 \\
\hline ARAP3 & -2.36298 & $6.30 \mathrm{E}-05$ & 0.001029 & -4.0011 & Down & ArfGAP with RhoGAP domain, ankyrin repeat and PH domain 3 \\
\hline DCX & -2.35488 & $5.92 \mathrm{E}-10$ & $4.60 \mathrm{E}-08$ & -6.19261 & Down & doublecortin \\
\hline DOK6 & -2.35163 & 0.001404 & 0.012641 & -3.19388 & Down & docking protein 6 \\
\hline REM2 & -2.33807 & 0.000734 & 0.007608 & -3.37667 & Down & RRAD and GEM like GTPase 2 \\
\hline MST1R & -2.33382 & 0.000891 & 0.008939 & -3.32291 & Down & macrophage stimulating 1 receptor \\
\hline
\end{tabular}


bioRxiv preprint doi: https://doi.org/10.1101/2021.03.28.437386; this version posted May 10, 2021. The copyright holder for this preprint (which was not certified by peer review) is the author/funder. All rights reserved. No reuse allowed without permission.

\begin{tabular}{|c|c|c|c|c|c|c|}
\hline ADCK2 & -2.33367 & 4.19E-07 & $1.53 \mathrm{E}-05$ & -5.05994 & Down & aarF domain containing kinase 2 \\
\hline ZNF382 & -2.33358 & $1.08 \mathrm{E}-06$ & $3.48 \mathrm{E}-05$ & -4.87723 & Down & zinc finger protein 382 \\
\hline ITPKB & -2.33313 & $8.26 \mathrm{E}-05$ & 0.001283 & -3.93677 & Down & inositol-trisphosphate 3-kinase B \\
\hline TCF7L1 & -2.32815 & 4.07E-06 & 0.000106 & -4.6079 & Down & transcription factor 7 like 1 \\
\hline COLEC11 & -2.32755 & 0.005638 & 0.035504 & -2.76815 & Down & collectin subfamily member 11 \\
\hline RTEL1 & -2.3271 & 0.002213 & 0.017864 & -3.05999 & Down & regulator of telomere elongation helicase 1 \\
\hline PLAU & -2.32405 & $4.95 \mathrm{E}-10$ & $3.93 \mathrm{E}-08$ & -6.22066 & Down & plasminogen activator, urokinase \\
\hline ZNF225 & -2.32232 & $1.94 \mathrm{E}-05$ & 0.000392 & -4.27161 & Down & zinc finger protein 225 \\
\hline TEKT2 & -2.32148 & $7.70 \mathrm{E}-05$ & 0.001207 & -3.9537 & Down & tektin 2 \\
\hline SNORD116-20 & -2.32074 & 0.000412 & 0.004825 & -3.53253 & Down & small nucleolar RNA, C/D box 116-20 \\
\hline PLXNA4 & -2.31931 & 0.007018 & 0.041668 & -2.69601 & Down & plexin A4 \\
\hline LYG1 & -2.31421 & 0.001683 & 0.014407 & -3.14107 & Down & lysozyme g1 \\
\hline KLRK1 & -2.31205 & 5.92E-07 & $2.05 \mathrm{E}-05$ & -4.99391 & Down & killer cell lectin like receptor $\mathrm{K} 1$ \\
\hline PPP4R1L & -2.30845 & 0.000193 & 0.002608 & -3.72846 & Down & protein phosphatase 4 regulatory subunit 1 like (pseudogene) \\
\hline RAB36 & -2.30784 & $1.33 \mathrm{E}-07$ & $5.62 \mathrm{E}-06$ & -5.27483 & Down & RAB36, member RAS oncogene family \\
\hline GPRC5A & -2.30755 & $1.59 \mathrm{E}-07$ & $6.56 \mathrm{E}-06$ & -5.24219 & Down & $\begin{array}{l}\text { G protein-coupled receptor class } \mathrm{C} \text { group } 5 \text { member } \mathrm{A} \\
\text { microtubule associated monooxygenase, calponin and LIM domain }\end{array}$ \\
\hline MICAL2 & -2.30536 & $4.40 \mathrm{E}-10$ & $3.55 \mathrm{E}-08$ & -6.23919 & Down & containing 2 \\
\hline CNN1 & -2.30412 & 0.006192 & 0.038125 & -2.73741 & Down & calponin 1 \\
\hline CABLES1 & -2.28816 & $5.14 \mathrm{E}-05$ & 0.000873 & -4.04934 & Down & Cdk5 and Abl enzyme substrate 1 \\
\hline HEY1 & -2.28283 & $1.51 \mathrm{E}-06$ & 4.69E-05 & -4.80928 & Down & hes related family bHLH transcription factor with YRPW motif 1 \\
\hline STAMBPL1 & -2.2809 & 0.0002 & 0.002685 & -3.71904 & Down & STAM binding protein like 1 \\
\hline FILIP1 & -2.27926 & 0.000297 & 0.003712 & -3.6177 & Down & filamin A interacting protein 1 \\
\hline TCF19 & -2.27043 & 0.005182 & 0.033297 & -2.79551 & Down & transcription factor 19 \\
\hline ADM2 & -2.2693 & $7.21 \mathrm{E}-05$ & 0.00115 & -3.96924 & Down & adrenomedullin 2 \\
\hline F2RL3 & -2.26218 & 0.006973 & 0.041522 & -2.69811 & Down & F2R like thrombin or trypsin receptor 3 \\
\hline JAK3 & -2.25837 & $7.02 \mathrm{E}-10$ & 5.27E-08 & -6.16561 & Down & Janus kinase 3 \\
\hline AMPD3 & -2.25431 & $1.17 \mathrm{E}-07$ & $5.02 \mathrm{E}-06$ & -5.29776 & Down & adenosine monophosphate deaminase 3 \\
\hline LOC283922 & -2.25375 & 0.000198 & 0.002659 & -3.72171 & Down & pyruvate dehydrogenase phosphatase regulatory subunit pseudogene \\
\hline PRC1 & -2.24885 & 0.001354 & 0.012271 & -3.20439 & Down & protein regulator of cytokinesis 1 \\
\hline OMD & -2.2486 & 0.000424 & 0.004948 & -3.5246 & Down & osteomodulin \\
\hline CAPN3 & -2.2486 & 0.000375 & 0.004463 & -3.55721 & Down & calpain 3 \\
\hline CENPL & -2.24563 & 0.000284 & 0.003592 & -3.62991 & Down & centromere protein $\mathrm{L}$ \\
\hline AGPAT4 & -2.24338 & $1.76 \mathrm{E}-08$ & $9.81 \mathrm{E}-07$ & -5.63375 & Down & 1-acylglycerol-3-phosphate O-acyltransferase 4 \\
\hline TNFRSF9 & -2.24232 & 0.000673 & 0.007129 & -3.40031 & Down & TNF receptor superfamily member 9 \\
\hline THBS2 & -2.23939 & $1.53 \mathrm{E}-08$ & 8.69E-07 & -5.65772 & Down & thrombospondin 2 \\
\hline GATA4 & -2.23356 & 0.001673 & 0.014344 & -3.14287 & Down & GATA binding protein 4 \\
\hline ZNF578 & -2.22449 & $5.95 \mathrm{E}-11$ & 5.93E-09 & -6.54494 & Down & zinc finger protein 578 \\
\hline NLRP1 & -2.22383 & 0.005604 & 0.035369 & -2.77008 & Down & NLR family pyrin domain containing 1 \\
\hline IFITM1 & -2.22304 & $5.17 \mathrm{E}-12$ & $6.34 \mathrm{E}-10$ & -6.90092 & Down & interferon induced transmembrane protein 1 \\
\hline CDCA7L & -2.21912 & 0.000175 & 0.002415 & -3.75311 & Down & cell division cycle associated 7 like \\
\hline SULF2 & -2.21472 & 7.92E-11 & 7.69E-09 & -6.5021 & Down & sulfatase 2 \\
\hline MMP11 & -2.21439 & 4.16E-06 & 0.000108 & -4.60305 & Down & matrix metallopeptidase 11 \\
\hline
\end{tabular}




\begin{tabular}{|c|c|c|c|c|c|c|}
\hline NGF & -2.2138 & 0.008589 & 0.048333 & -2.62798 & Down & nerve growth factor \\
\hline IL1RAP & -2.2124 & $8.29 \mathrm{E}-09$ & 4.96E-07 & -5.76255 & Down & interleukin 1 receptor accessory protein \\
\hline ASPN & -2.21173 & $9.25 \mathrm{E}-05$ & 0.001406 & -3.90938 & Down & asporin \\
\hline KLHDC8B & -2.20812 & 4.15E-07 & $1.52 \mathrm{E}-05$ & -5.06209 & Down & kelch domain containing $8 \mathrm{~B}$ \\
\hline EFNA4 & -2.20663 & 0.008279 & 0.047176 & -2.64048 & Down & ephrin A4 \\
\hline CTHRC1 & -2.20605 & $6.86 \mathrm{E}-06$ & 0.000164 & -4.49806 & Down & collagen triple helix repeat containing 1 \\
\hline OLFM1 & -2.20308 & 7.85E-09 & 4.76E-07 & -5.77156 & Down & olfactomedin 1 \\
\hline CETN4P & -2.19988 & 0.00501 & 0.032446 & -2.80642 & Down & centrin 4 , pseudogene \\
\hline NFE2L3 & -2.19936 & $4.59 \mathrm{E}-06$ & 0.000116 & -4.58292 & Down & nuclear factor, erythroid 2 like 3 \\
\hline KIF14 & -2.19759 & 0.008838 & 0.04936 & -2.61825 & Down & kinesin family member 14 \\
\hline SNORD57 & -2.19175 & $1.87 \mathrm{E}-05$ & 0.000381 & -4.27993 & Down & small nucleolar RNA, C/D box 57 \\
\hline LPAR6 & -2.18519 & $4.28 \mathrm{E}-11$ & 4.32E-09 & -6.59411 & Down & lysophosphatidic acid receptor 6 \\
\hline PLAT & -2.18436 & $6.98 \mathrm{E}-09$ & 4.28E-07 & -5.79147 & Down & plasminogen activator, tissue type \\
\hline FUT4 & -2.1843 & 4.79E-08 & 2.30E-06 & -5.459 & Down & fucosyltransferase 4 \\
\hline ANKRD36BP2 & -2.18367 & $1.37 \mathrm{E}-09$ & $9.50 \mathrm{E}-08$ & -6.0584 & Down & ankyrin repeat domain $36 \mathrm{~B}$ pseudogene 2 \\
\hline ZNF74 & -2.18352 & $3.01 \mathrm{E}-06$ & $8.17 \mathrm{E}-05$ & -4.66989 & Down & zinc finger protein 74 \\
\hline TMEM204 & -2.17915 & 0.007828 & 0.0452 & -2.65939 & Down & transmembrane protein 204 \\
\hline GFPT2 & -2.17823 & $1.08 \mathrm{E}-06$ & $3.50 \mathrm{E}-05$ & -4.87557 & Down & glutamine-fructose-6-phosphate transaminase 2 \\
\hline C22orf42 & -2.17509 & $1.42 \mathrm{E}-06$ & $4.45 \mathrm{E}-05$ & -4.82203 & Down & chromosome 22 open reading frame 42 \\
\hline NHS & -2.17259 & $1.37 \mathrm{E}-05$ & 0.000297 & -4.34817 & Down & NHS actin remodeling regulator \\
\hline EFS & -2.16928 & 0.004816 & 0.031576 & -2.81908 & Down & embryonal Fyn-associated substrate \\
\hline ADAM19 & -2.16658 & 1.99E-08 & $1.08 \mathrm{E}-06$ & -5.61289 & Down & ADAM metallopeptidase domain 19 \\
\hline АРОВEC3B & -2.16319 & $6.86 \mathrm{E}-06$ & 0.000164 & -4.49784 & Down & apolipoprotein B mRNA editing enzyme catalytic subunit 3B \\
\hline CHTF18 & -2.16232 & 0.00212 & 0.017258 & -3.07291 & Down & chromosome transmission fidelity factor 18 \\
\hline KNDC1 & -2.15888 & $6.74 \mathrm{E}-05$ & 0.001089 & -3.98525 & Down & kinase non-catalytic C-lobe domain containing 1 \\
\hline CHEK1 & -2.15805 & $1.94 \mathrm{E}-05$ & 0.000392 & -4.27124 & Down & checkpoint kinase 1 \\
\hline MCAM & -2.15289 & $3.80 \mathrm{E}-07$ & $1.41 \mathrm{E}-05$ & -5.07866 & Down & melanoma cell adhesion molecule \\
\hline LCP1 & -2.15194 & 4.07E-05 & 0.000715 & -4.10363 & Down & lymphocyte cytosolic protein 1 \\
\hline LRFN5 & -2.14996 & 0.006628 & 0.039915 & -2.71496 & Down & leucine rich repeat and fibronectin type III domain containing 5 \\
\hline ACSM3 & -2.14536 & $2.20 \mathrm{E}-10$ & 1.88E-08 & -6.34645 & Down & acyl-CoA synthetase medium chain family member 3 \\
\hline DCAF4 & -2.1387 & $1.56 \mathrm{E}-05$ & 0.000326 & -4.32021 & Down & DDB1 and CUL4 associated factor 4 \\
\hline MTBP & -2.13416 & 0.001085 & 0.010338 & -3.2676 & Down & MDM2 binding protein \\
\hline KLHL1 & -2.13391 & 0.002973 & 0.022264 & -2.97051 & Down & kelch like family member 1 \\
\hline VANGL1 & -2.12864 & $1.83 \mathrm{E}-06$ & $5.51 \mathrm{E}-05$ & -4.77175 & Down & VANGL planar cell polarity protein 1 \\
\hline GPX8 & -2.1259 & $3.62 \mathrm{E}-09$ & $2.34 \mathrm{E}-07$ & -5.90058 & Down & glutathione peroxidase 8 (putative) \\
\hline LOC100379224 & -2.12575 & $1.98 \mathrm{E}-06$ & $5.82 \mathrm{E}-05$ & -4.7552 & Down & uncharacterized LOC100379224 \\
\hline TIPIN & -2.1246 & $1.64 \mathrm{E}-05$ & 0.000341 & -4.30951 & Down & TIMELESS interacting protein \\
\hline SPRY4 & -2.12151 & $2.05 \mathrm{E}-06$ & $5.98 \mathrm{E}-05$ & -4.74849 & Down & sprouty RTK signaling antagonist 4 \\
\hline PTPRE & -2.11764 & $7.05 \mathrm{E}-09$ & $4.31 \mathrm{E}-07$ & -5.78979 & Down & protein tyrosine phosphatase receptor type $\mathrm{E}$ \\
\hline C10orf55 & -2.11758 & 0.000531 & 0.005903 & -3.46456 & Down & chromosome 10 putative open reading frame 55 \\
\hline EMP1 & -2.11626 & $1.21 \mathrm{E}-08$ & 7.01E-07 & -5.69857 & Down & epithelial membrane protein 1 \\
\hline ZNF660 & -2.11231 & $1.86 \mathrm{E}-06$ & $5.57 \mathrm{E}-05$ & -4.76806 & Down & zinc finger protein 660 \\
\hline H19 & -2.11172 & 7.49E-07 & 2.52E-05 & -4.94826 & Down & H19 imprinted maternally expressed transcript \\
\hline
\end{tabular}




\begin{tabular}{|c|c|c|c|c|c|c|}
\hline TBXA2R & -2.10662 & 0.008229 & 0.047003 & -2.64251 & Down & thromboxane $\mathrm{A} 2$ receptor \\
\hline USP6 & -2.10526 & $7.52 \mathrm{E}-06$ & 0.000178 & -4.47843 & Down & ubiquitin specific peptidase 6 \\
\hline LAMA2 & -2.10455 & $3.11 \mathrm{E}-05$ & 0.000579 & -4.16536 & Down & laminin subunit alpha 2 \\
\hline LOC154761 & -2.10453 & $9.94 \mathrm{E}-05$ & 0.001494 & -3.89211 & Down & family with sequence similarity 115 , member $\mathrm{C}$ pseudogene \\
\hline HHLA2 & -2.1032 & 0.001625 & 0.014049 & -3.15132 & Down & HERV-H LTR-associating 2 \\
\hline ZNF350 & -2.09835 & $6.03 \mathrm{E}-08$ & $2.80 \mathrm{E}-06$ & -5.41803 & Down & zinc finger protein 350 \\
\hline GPR82 & -2.09727 & 0.000466 & 0.005327 & -3.49961 & Down & G protein-coupled receptor 82 \\
\hline RPTOR & -2.09525 & 4.42E-05 & 0.000768 & -4.08461 & Down & regulatory associated protein of MTOR complex 1 \\
\hline PRPH2 & -2.09306 & $2.24 \mathrm{E}-05$ & 0.000442 & -4.23918 & Down & peripherin 2 \\
\hline SYTL2 & -2.09238 & $9.57 \mathrm{E}-06$ & 0.000218 & -4.4266 & Down & synaptotagmin like 2 \\
\hline ZNF577 & -2.09237 & $5.29 \mathrm{E}-05$ & 0.000894 & -4.04223 & Down & zinc finger protein 577 \\
\hline CHL1 & -2.09068 & $5.84 \mathrm{E}-05$ & 0.000967 & -4.01912 & Down & cell adhesion molecule L1 like \\
\hline DNAJC22 & -2.08584 & $2.39 \mathrm{E}-06$ & $6.69 \mathrm{E}-05$ & -4.71712 & Down & DnaJ heat shock protein family (Hsp40) member $\mathrm{C} 22$ \\
\hline SPARCL1 & -2.08481 & $1.46 \mathrm{E}-05$ & 0.00031 & -4.3342 & Down & SPARC like 1 \\
\hline CXCR4 & -2.08402 & 7.59E-05 & 0.001192 & -3.95705 & Down & $\mathrm{C}-\mathrm{X}-\mathrm{C}$ motif chemokine receptor 4 \\
\hline EPPK1 & -2.08312 & $5.17 \mathrm{E}-08$ & $2.47 \mathrm{E}-06$ & -5.44552 & Down & epiplakin 1 \\
\hline ATAT1 & -2.07916 & $1.13 \mathrm{E}-07$ & $4.85 \mathrm{E}-06$ & -5.30486 & Down & alpha tubulin acetyltransferase 1 \\
\hline RYR3 & -2.07755 & 0.00289 & 0.021795 & -2.97916 & Down & ryanodine receptor 3 \\
\hline PRR11 & -2.07467 & 0.000171 & 0.002372 & -3.7581 & Down & proline rich 11 \\
\hline ZNF624 & -2.06913 & $2.27 \mathrm{E}-05$ & 0.000447 & -4.23646 & Down & zinc finger protein 624 \\
\hline ARHGAP6 & -2.06665 & 0.004771 & 0.031366 & -2.82207 & Down & Rho GTPase activating protein 6 \\
\hline FAT4 & -2.06599 & 0.000946 & 0.009363 & -3.30624 & Down & FAT atypical cadherin 4 \\
\hline LOC374443 & -2.06089 & 0.00379 & 0.026492 & -2.89513 & Down & C-type lectin domain family 2 member D pseudogene \\
\hline FGG & -2.05957 & 0.002532 & 0.019815 & -3.01947 & Down & fibrinogen gamma chain \\
\hline STK10 & -2.05632 & 4.63E-06 & 0.000117 & -4.5811 & Down & serine/threonine kinase 10 \\
\hline TEAD3 & -2.0544 & $8.36 \mathrm{E}-05$ & 0.00129 & -3.93384 & Down & TEA domain transcription factor 3 \\
\hline ZNF778 & -2.05438 & 0.006697 & 0.040233 & -2.71153 & Down & zinc finger protein 778 \\
\hline ZNF564 & -2.052 & $1.00 \mathrm{E}-07$ & 4.41E-06 & -5.32623 & Down & zinc finger protein 564 \\
\hline FAM200A & -2.05146 & $1.68 \mathrm{E}-06$ & $5.12 \mathrm{E}-05$ & -4.7889 & Down & family with sequence similarity 200 member A \\
\hline IGF2 & -2.05109 & $6.07 \mathrm{E}-14$ & $9.69 \mathrm{E}-12$ & -7.50655 & Down & insulin like growth factor 2 \\
\hline BACH2 & -2.05081 & $1.83 \mathrm{E}-06$ & $5.51 \mathrm{E}-05$ & -4.77135 & Down & BTB domain and CNC homolog 2 \\
\hline LRRC37B & -2.0495 & $9.93 \mathrm{E}-08$ & 4.38E-06 & -5.32793 & Down & leucine rich repeat containing 37B \\
\hline NOX5 & -2.04697 & 0.003455 & 0.024799 & -2.92404 & Down & NADPH oxidase 5 \\
\hline DDR2 & -2.04377 & 4.94E-07 & $1.77 \mathrm{E}-05$ & -5.02879 & Down & discoidin domain receptor tyrosine kinase 2 \\
\hline FOXQ1 & -2.04319 & 0.000588 & 0.006397 & -3.43689 & Down & forkhead box Q1 \\
\hline TMEM116 & -2.04083 & 3.23E-08 & $1.66 \mathrm{E}-06$ & -5.52823 & Down & transmembrane protein 116 \\
\hline RNF138P1 & -2.03873 & $1.47 \mathrm{E}-05$ & 0.00031 & -4.33385 & Down & ring finger protein 138 pseudogene 1 \\
\hline MEX3A & -2.03718 & 0.000573 & 0.006263 & -3.4442 & Down & mex-3 RNA binding family member A \\
\hline SEMA3A & -2.03545 & $9.14 \mathrm{E}-05$ & 0.001393 & -3.91241 & Down & semaphorin $3 \mathrm{~A}$ \\
\hline ZNF300P1 & -2.03197 & 0.002385 & 0.018952 & -3.03753 & Down & zinc finger protein 300 pseudogene 1 \\
\hline NAA40 & -2.0275 & $1.04 \mathrm{E}-09$ & 7.43E-08 & -6.10309 & Down & $\mathrm{N}$-alpha-acetyltransferase $40, \mathrm{NatD}$ catalytic subunit \\
\hline DAND5 & -2.02131 & 0.000699 & 0.00735 & -3.38988 & Down & DAN domain BMP antagonist family member 5 \\
\hline TFF1 & -2.0112 & 0.004679 & 0.030977 & -2.82835 & Down & trefoil factor 1 \\
\hline
\end{tabular}


bioRxiv preprint doi: https://doi.org/10.1101/2021.03.28.437386; this version posted May 10, 2021. The copyright holder for this preprint (which was not certified by peer review) is the author/funder. All rights reserved. No reuse allowed without permission.

\begin{tabular}{ccccccc}
\hline NOTCH3 & -2.00738 & $2.63 \mathrm{E}-08$ & $1.38 \mathrm{E}-06$ & -5.56445 & Down & notch receptor 3 \\
RRN3P2 & -2.00495 & $2.82 \mathrm{E}-05$ & 0.000538 & -4.18763 & Down & RRN3 pseudogene 2 \\
RFTN1 & -2.00494 & 0.006985 & 0.041558 & -2.69758 & Down & uftlin, lipid raft linker 1 \\
USH2A & -2.00478 & 0.00357 & 0.025308 & -2.91384 & Down & heparanase \\
HPSE & -2.00475 & 0.003458 & 0.024806 & -2.92381 & Down & NFKB activating protein like \\
NKAPL & -2.00325 & $1.27 \mathrm{E}-05$ & 0.000277 & -4.3652 & Down & diacylglycerol kinase delta \\
DGKD & -2.00014 & $3.76 \mathrm{E}-09$ & $2.42 \mathrm{E}-07$ & -5.89422 & Down & Rho GTPase activating protein 31 \\
ARHGAP31 & -1.9977 & 0.000157 & 0.002214 & -3.77925 & Down & zinc finger protein 565 \\
ZNF565 & -1.99447 & 0.001321 & 0.012061 & -3.21146 & Down & chromosome 2 open reading frame 88 \\
C2orf88 & -1.99129 & 0.000208 & 0.002777 & -3.70889 & Down &
\end{tabular}

Table 3 The enriched GO terms of the up and down regulated differentially expressed genes

$\begin{array}{llllllll}\text { GO ID CATEgORY GO Name } & \text { P Value } & \text { FDR } & \text { FDR } & \text { Bonferroni } & \text { Gene } & \text { Count }\end{array}$

Up regulated genes

\begin{tabular}{|c|c|c|c|c|c|c|c|c|}
\hline GO:0006952 & $\mathrm{BP}$ & $\begin{array}{l}\text { defense } \\
\text { response }\end{array}$ & $3.72 \mathrm{E}-10$ & $2.20 \mathrm{E}-06$ & $2.03 \mathrm{E}-05$ & $2.20 \mathrm{E}-06$ & 84 & $\begin{array}{l}\text { HIF1A,HLA-A,HLA- } \\
\text { B,HLA-C,HLA-DPB1,HLA- } \\
\text { DRA,HLA- } \\
\text { DRB1,PENK,HLA-E,HLA- } \\
\text { F,HLA- } \\
\text { H,TUSC2,CHI3L1,ADORA } \\
\text { 2A,SAA1,SAA2,SERPINA } \\
\text { 1,ADRB2,CLU,AGT,FGA, } \\
\text { CCL20, HSPA1B,VCAM1, } \\
\text { MUC20, DUOXA2,MRC1, } \\
\text { ZC3H12A,UBD,MUC15,A } \\
\text { PCS,BIRC3,DUOX2,IFITM } \\
\text { 2,PPARA,MUC13,SUCNR } \\
\text { 1,APOL1,RAB20,CRH,ZFP } \\
\text { 36,PPM1B,CRP,PLA2G4C } \\
\text {,DUOXA1,SLPI,SOCS1,SN } \\
\text { CA,CYP4F11,ABHD12,CT } \\
\text { SS,IL6R,DAB2IP,SPP1,GB } \\
\text { P2,ITGAX,GRAM D4,CFB, } \\
\text { DEFB1,JUN,VNN1,KCNJ8 } \\
\text {,SERPING1,C1R,C4BPA,K } \\
\text { LKB1,KYNU,RAB27A,NR1 } \\
\text { H4,DPP4,RARRES2,GPX2 } \\
\text {,CASP1,RELA,LCN2,CXCL } \\
\text { 2,LDLR,ORM1,GSDMD,R } \\
\text { EG3A,CD74,RORA,CD81, } \\
\text { LYZ }\end{array}$ \\
\hline GO:0046903 & $\mathrm{BP}$ & secretion & $3.05 \mathrm{E}-09$ & $3.40 \mathrm{E}-06$ & $3.15 \mathrm{E}-05$ & $1.80 \mathrm{E}-05$ & 81 & $\begin{array}{l}\text { ERBB3,HIF1A,HLA- } \\
\text { E,HLA-F,HLA- } \\
\text { H,PFLL,CHI3L1,TTR,LRG1 } \\
\text {,ADORA2A,SAA1,SERPIN } \\
\text { A1,SERPINE2,ADRB1,AD } \\
\text { RB2,PIGR,CLU,AGT,FGA, } \\
\text { ALB,C1QTNF4,HSPA1B,S }\end{array}$ \\
\hline
\end{tabular}


bioRxiv preprint doi: https://doi.org/10.1101/2021.03.28.437386; this version posted May 10, 2021. The copyright holder for this preprint (which was not certified by peer review) is the author/funder. All rights reserved. No reuse allowed without permission.

\begin{tabular}{|c|c|c|c|c|c|c|c|c|}
\hline GO:0099503 & $\mathrm{CC}$ & $\begin{array}{l}\text { secretory } \\
\text { vesicle }\end{array}$ & $1.46 \mathrm{E}-07$ & $8.06 \mathrm{E}-06$ & $5.73 \mathrm{E}-05$ & $9.94 \mathrm{E}-05$ & 52 & $\begin{array}{l}\text { PCSK2,PENK,HLA- } \\
\text { H,CHGB,PFKL,CHI3L1,TT } \\
\text { R,LRG1,SERPINA1,SERPI } \\
\text { NE2,PIGR,CLU,SCNN1A,F } \\
\text { GA,ALB,HSPA1B,DPP7,C } \\
\text { LIP2,APOH,MMRN1,CAR } \\
\text { TPT,STX19,ARSA,SLPI,FT } \\
\text { H1,SNCA,CTSD,CTSS,GA } \\
\text { A,GABBR1,GCG, ITGAX,P } \\
\text { GRMC1,QSOX1,KCNC4,P } \\
\text { TPRN2,VNN1,CYB5R3,SE } \\
\text { RPING1,KCNQ1,PCSK1N, } \\
\text { RAB27A,RAB5C,CA4,RAP } \\
\text { 1A,ROGDI,RARRES2,LCN } \\
\text { 2,ORM1,RNPEP,GSDMD, } \\
\text { LYZ }\end{array}$ \\
\hline GO:0005794 & $\mathrm{CC}$ & Golgi apparatus & $9.60 \mathrm{E}-06$ & $2.85 \mathrm{E}-04$ & 2.03E-03 & $6.56 \mathrm{E}-03$ & 64 & $\begin{array}{l}\text { MAN1A1,GCNT3,HLA- } \\
\text { A,HLA-B,HLA- } \\
\text { C,BET1,HLA-DPB1,HLA- } \\
\text { DRA,TRAPPC5,HLA- } \\
\text { DRB1,DAPK2,HLA- } \\
\text { E,HLA-F,HLA- } \\
\text { H,PLEKHB1,RTN1,F10,A } \\
\text { BCB1,ADORA2A,SERPIN } \\
\text { A1,RAB33A,CLU,SEC24B, } \\
\text { DDX54,ALB,SDC4,VCAM } \\
\text { 1,MUC20,DPP7,MUC15, } \\
\text { ST8SIA1,MUC13,RAB20, } \\
\text { GBA2,STS,PSMG1,CERS1 } \\
\text {,SNCA,FAM20A,GGA1,T } \\
\text { MEM30B,GGA2,GALNT3 } \\
\text {,SPP1,GBP2,GNPTG,DEF } \\
\text { B1,QSOX1,KCNC4,DHCR } \\
\text { 24,PCSK1N,RAB27A,CA4 } \\
\text {,DPP4,RAP1GAP,SCYL3, } \\
\text { NUCB1,STEAP4,OCRL,GR } \\
\text { INA,LDLR,RNPEP,CD74,K }\end{array}$ \\
\hline
\end{tabular}


bioRxiv preprint doi: https://doi.org/10.1101/2021.03.28.437386; this version posted May 10, 2021. The copyright holder for this preprint (which was not certified by peer review) is the author/funder. All rights reserved. No reuse allowed without permission.

\begin{tabular}{|c|c|c|c|c|c|c|c|c|}
\hline & & & & & & & & LHL12 \\
\hline GO:0042802 & MF & $\begin{array}{l}\text { identical } \\
\text { protein binding }\end{array}$ & 7.07E-06 & $9.36 \mathrm{E}-04$ & 7.17E-03 & $8.43 E-03$ & 77 & $\begin{array}{l}\text { ERBB3,CEBPD,ZBTB48,M } \\
\text { AT1A,DAPK2,PEX7,OIP5, } \\
\text { PFKL,NR4A1,PLEKHB1,T } \\
\text { TR,F11,PGR,ADH1C,ADO } \\
\text { RA2A,SERPINA1,ADRB2, } \\
\text { PLIN5,MAP3K9,ALB,ALD } \\
\text { H2,ALDOB,SDC4,MOCS2 } \\
\text {,AMBP, NECAB2,ANG,AN } \\
\text { XA4,AOX1,APCS,PON3,C } \\
\text { LDN7,MUC13,APOH,CRP } \\
\text {,ASL,FTH1,SNCA,SLC4A4, } \\
\text { PRLR,IL6R,MVD,SOD2,D } \\
\text { AB2IP,IMPA2,GAMT,GB } \\
\text { P2,LHPP,GCG,S100Z,GN } \\
\text { PTG,DEFB1,RASSF5,JUN, } \\
\text { KCNQ1,KYNU,DPP4,RAP } \\
\text { 1GAP,NUDT16,NR4A2,C } \\
\text { ASP1,NR4A3,RELA,LCN2, } \\
\text { TYMP,LDLR,TFRC,MLXIP } \\
\text { L,CDH22,RPRD1A,P4HA1 } \\
\text {,REG3A,CD74,KLHL12,LY } \\
\text { Z,CDH17,MAF }\end{array}$ \\
\hline GO:0022857 & MF & $\begin{array}{l}\text { transmembran } \\
\text { e transporter } \\
\text { activity }\end{array}$ & $7.16 \mathrm{E}-04$ & $2.84 \mathrm{E}-02$ & $2.18 \mathrm{E}-01$ & $8.53 \mathrm{E}-01$ & 50 & $\begin{array}{l}\text { PDE4D,SLC24A3,SLC22A } \\
\text { 17,CHRNE,ABCB1, KCNH } \\
\text { 6,ADRB1,ADRB2,COX5A, } \\
\text { SCN3A,SCNN1A,CNGA1, } \\
\text { AMBP, HCN3,SLC34A2,A } \\
\text { POL1,CRH,SHANK2,SLC1 } \\
\text { 7A1,SLCO1A2,SLC6A20, } \\
\text { C15orf48,SNCA,SLC4A4, } \\
\text { SLC12A7,CTSS,CACNA2D } \\
\text { 3,GABRE,CHCHD10,SLC3 } \\
\text { 9A1,SLC28A3,GC,KCNC4, } \\
\text { KCNJ8,SLMAP,KCNK3,KC } \\
\text { NQ1,CACNA1H,SLC29A4 } \\
\text {,CACNA1A,SLC38A4,SLC } \\
\text { 19A3,SLC44A4,ATP13A2 } \\
\text {,TFRC,SLC25A36,TMC5,S } \\
\text { LC25A19,SLC16A7,CDH1 } \\
7\end{array}$ \\
\hline
\end{tabular}

Down regulated genes

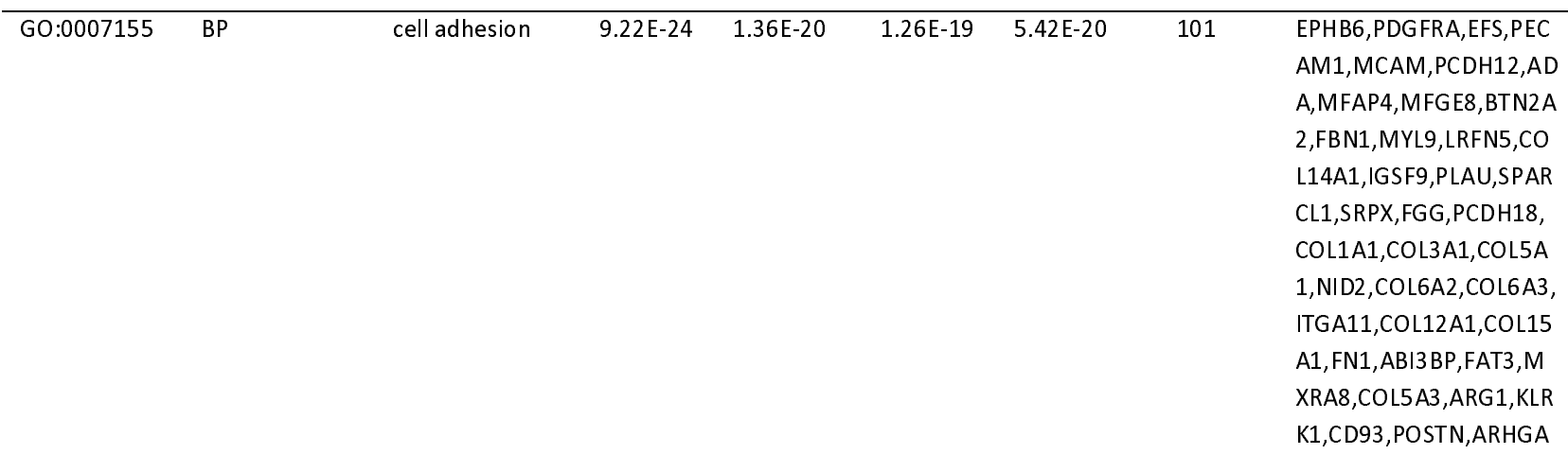


bioRxiv preprint doi: https://doi.org/10.1101/2021.03.28.437386; this version posted May 10, 2021. The copyright holder for this preprint (which was not certified by peer review) is the author/funder. All rights reserved. No reuse allowed without permission.

$\begin{array}{llllll}\text { localization of } \quad 1.21 \mathrm{E}-15 & 4.46 \mathrm{E}-13 \quad 4.13 \mathrm{E}-12 & 7.14 \mathrm{E}-12 & 100\end{array}$ cell

GO:0031012 CC

extracellular matrix
P6,IGF2, VCAN,SNAI2,CN TNAP2,PLXNA4, DCHS1,I L1RAP,MUC4,NEXN,CHL 1,IL18,ADAM19,PCDHB5 ,LAMA1,ISLR, HPSE,ITPK B,PTN,JAK3,STK10,BMP 4,NTNG2,SRPX2,CLEC4A ,CXCR4,NTM,GLI2,KIF14, NID1,KDR, KIT, UNC5D,FA T4,KIF26B,ECM2,DDR2, AKNA,LAMA2,LAMA4,ES AM,PRPH2,OMD,S1PR1, ADAMTS12, TGFBI,HHLA 2,THBS1,THBS2,EFNB2,T HY1,CD34,SERPINE1,M MRN2,TNFAIP6,HAS2,LE $\mathrm{F} 1, \mathrm{CDH} 5, \mathrm{PCDH} 7, \mathrm{CDH} 6, \mathrm{C}$ DH11, FRMD5, CDH13

SYNPO2,ERG,PDGFB,PD GFRA, EFS, PECAM1,ACT A2,MCAM,SOX18, ADA,F 2R,PGF,SEMA3A,WNT5B ,ADORA2B,ANLN, ASPM, HRH1,CTHRC1,OLFM1,P LAT,PLAU,MMP9,RSPH9 ,COL1A1,COL1A2,COL3A 1,COL5A1,SEMA3C,ITGA 11,FN1, DLL4,FAT3, IFITM 1, KLRK1, POSTN, IGF2,VC AN,SNAI2,PLXNA4,DCHS 1,GLIPR2, NRG3,NEXN,SI X2,CHL1, IL16,SPARC, IL1

8,EPPK1,LAMA1,TUBB2B ,SST,DCX,PTGS2,PTN,ST K10,BMP4,TEKT2,SRPX2, GPC3,CXCR4,SULF1, KIF1 4,KDR, KIT, UNC5D,TBXA 2R,TMSB15A, RIP K3,CD2 48,FFAR2, DDR2,LAMA2, LAMA4, ESAM, LCP1,ECM 1,S1PR1,EDNRA,ADAMT S12,THBS1, ARAP3,EFNB 2,EGF,THY1,LOX,CD34,S ERPINE1,MMRN2,SLC7A 5,CDK1, TNFAIP6, HAS2, L EF1,PADI2,CDH5, ENPEP, FRMD5,CDH13

A2M,PDGFB, COL22A1,C OLQ,WNT5B,MFAP2,MF AP4,MFGE8, FBN1,FBN2, MGP,AEBP1,CTHRC1,CO L14A1,PLAT,SPARCL1,SR PX,MMP3,FGG,MMP9, MMP11,USH2A,COL1A1, COL1A2,COL3A1,COL4A 
bioRxiv preprint doi: https://doi.org/10.1101/2021.03.28.437386; this version posted May 10, 2021. The copyright holder for this preprint (which was not certified by peer review) is the author/funder. All rights reserved. No reuse allowed without permission.

\begin{tabular}{|c|c|c|c|c|c|c|c|c|}
\hline GO:0031226 & CC & $\begin{array}{l}\text { intrinsic } \\
\text { component of } \\
\text { plasma } \\
\text { membrane }\end{array}$ & $6.42 \mathrm{E}-07$ & $2.97 \mathrm{E}-05$ & $2.05 \mathrm{E}-04$ & $3.56 \mathrm{E}-04$ & 72 & $\begin{array}{l}\text { EPHB6,KCNH7,PDGFRA, } \\
\text { PCDH12,F2R,SEMA3A,A } \\
\text { DORA2B,LRFN5,UPK1B, } \\
\text { HRH1,OLFM1, ECEL1,M } \\
\text { ME,LTB4R,ALK,PCDH18, } \\
\text { LRRC8E,SEM A3C,ITGA11 } \\
\text {,DLL4,SGCD,TMPRSS11E } \\
\text {,SLC1A3,SLC2A2, IGDCC4 } \\
\text {,KLRK1,MST1R,SLCO2A1 } \\
\text {,SLC22A3,CNTNAP2,PLX } \\
\text { NA4,ULBP1,NRG3,IL1RA } \\
\text { P,MUC4,SLC16A10,TNFR } \\
\text { SF9,NOX5,PCDHB5,LRRC } \\
\text { 70,GGT5,GHR,GJA4,NTN } \\
\text { G2,GPC3,CLEC4A,GLRA1 } \\
\text {,TMEM150C,KDR,STRA6, } \\
\text { KIT,NOTCH3,TBXA2R,TR } \\
\text { PA1,F2RL3,FFAR2,DDR2, } \\
\text { ANO1,PRPH2,GPRC5A,S } \\
\text { 1PR1,S1PR3,EDNRA,EFN } \\
\text { A4,EFNB2,THY1,LPAR6,C } \\
\text { D34,CALCRL,HAS2,PCDH } \\
\text { 7,ENPEP }\end{array}$ \\
\hline GO:0005198 & $\mathrm{MF}$ & $\begin{array}{l}\text { structural } \\
\text { molecule } \\
\text { activity }\end{array}$ & $1.52 \mathrm{E}-13$ & $4.81 \mathrm{E}-11$ & $3.58 \mathrm{E}-10$ & $1.44 \mathrm{E}-10$ & 55 & $\begin{array}{l}\text { COL22A1,COLQ,MFAP2, } \\
\text { MFAP4,MFGE8,FBN1,FB } \\
\text { N2,MYL9,MGP,AEBP1,U } \\
\text { PK1B,CTHRC1,COL14A1, } \\
\text { SRPX,FGG,COL1A1,COL1 } \\
\text { A2,COL3A1,COL4A1,COL } \\
\text { 5A1,COL5A2,NID2,COL6 } \\
\text { A2,COL6A3,COL12A1,CO } \\
\text { L15A1,FN1,ABI3BP,COL5 } \\
\text { A3,POSTN,VCAN,MUC4, } \\
\text { NEXN,SNTB1,SPARC,EPP } \\
\text { K1,ASPN,LAMA1,TUBB2 } \\
\text { B,BGN,SRPX2,PXDN,NID } \\
\text { 1,KRT6B,KRT17,CAPN3,L } \\
\text { AMA2,LAMA4,ECM1,TG } \\
\text { FBI,THBS1,THBS2,MMR }\end{array}$ \\
\hline
\end{tabular}


bioRxiv preprint doi: https://doi.org/10.1101/2021.03.28.437386; this version posted May 10, 2021. The copyright holder for this preprint (which was not certified by peer review) is the author/funder. All rights reserved. No reuse allowed without permission.

N2,LTBP2,LUM

Biological Process(BP), Cellular Component(CC) and Molecular Functions (MF)

Table 4 The enriched pathway terms of the up and down regulated differentially expressed genes

\begin{tabular}{|c|c|c|c|c|c|c|c|}
\hline Pathway ID & $\begin{array}{c}\text { Pathway } \\
\text { Name }\end{array}$ & P-value & $\begin{array}{l}\text { FDR } \\
\text { B\&H }\end{array}$ & $\begin{array}{l}\text { FDR } \\
\text { B\&Y }\end{array}$ & Bonferroni & $\begin{array}{c}\text { Gene } \\
\text { Count }\end{array}$ & Gene \\
\hline \multicolumn{8}{|c|}{ Up regulated genes } \\
\hline 1457780 & $\begin{array}{c}\text { Neutrophil } \\
\text { degranulatio } \\
\mathrm{n}\end{array}$ & $6.39 \mathrm{E}-06$ & $1.26 \mathrm{E}-03$ & $9.10 \mathrm{E}-03$ & $5.03 \mathrm{E}-03$ & 31 & $\begin{array}{c}\text { HLA-A,HLA-B,HLA- } \\
\text { C,HLA- } \\
\text { H,PFKL,CHI3L1,TTR,L } \\
\text { RG1,SERPINA1,PIGR,H } \\
\text { SPA1B,DPP7,ARSA,SLP } \\
\text { I,FTH1,CTSD,CTSS,GA } \\
\text { A,ITGAX,PGRMC1,QS } \\
\text { OX1,PTPRN2,VNN1,CY } \\
\text { B5R3,RAB27A,RAB5C, } \\
\text { RAP1A,LCN2,ORM1,GS } \\
\text { DMD,LYZ }\end{array}$ \\
\hline 1269203 & $\begin{array}{c}\text { Innate } \\
\text { Immune } \\
\text { System }\end{array}$ & $9.95 \mathrm{E}-05$ & $1.31 \mathrm{E}-02$ & $9.45 \mathrm{E}-02$ & $7.83 \mathrm{E}-02$ & 57 & $\begin{array}{c}\text { ERBB3,HLA-A,HLA- } \\
\text { B,HLA-C,HLA-E,HLA- } \\
\text { H,PFKL,CHI3L1,NR4A1 } \\
\text {,TTR,LRG1,SAA1,SERP } \\
\text { INA1,PIGR,CLU,FGA,H } \\
\text { SPA1B,KLB,MUC20,DP } \\
\text { P7,LAT2,MUC15,BIRC3 } \\
\text {,MUC13,CRP,ARSA,SLP } \\
\text { I,FTH1,SOCS1,CTSD,CT } \\
\text { SS,GAA,DAB2IP,ITGA } \\
\text { X,PGRMC1,CFB,DEFB1 } \\
\text {,QSOX1,JUN,PTPRN2,V } \\
\text { NN1,CYB5R3,C1R,C4B } \\
\text { PA,RAB27A,RAB5C,RA } \\
\text { P1A,DUSP1,DUSP8,CA } \\
\text { SP1,CASP10,RELA,LCN } \\
\text { 2,ORM1,GSDMD,REG3 } \\
\text { A,LYZ }\end{array}$ \\
\hline 1269310 & $\begin{array}{l}\text { Cytokine } \\
\text { Signaling in } \\
\text { Immune } \\
\text { system }\end{array}$ & $9.77 \mathrm{E}-04$ & 5.91E-02 & 4.28E-01 & 7.69E-01 & 35 & $\begin{array}{c}\text { ERBB3,HIF1A,CEBPD, } \\
\text { HLA-A,HLA-B,HLA- } \\
\text { C,HLA-DPB1,HLA- } \\
\text { DRA,HLA-DRB1,HLA- } \\
\text { E,HLA-F,HLA- } \\
\text { H,SAA1,FGA,MMP1,CC } \\
\text { L20,VCAM1,KLB,BIRC } \\
\text { 3,IFITM2,PPM1B,SOCS } \\
\text { 1,PRLR,IL6R,DAB2IP,G } \\
\text { BP2,ITGAX,RAP1A,DU } \\
\text { SP1,DUSP8,CASP1,REL } \\
\text { A,LCN2,CXCL2,RORA }\end{array}$ \\
\hline 1270144 & $\begin{array}{l}\text { Metabolism } \\
\text { of vitamins }\end{array}$ & $2.57 \mathrm{E}-03$ & $1.36 \mathrm{E}-01$ & $9.83 \mathrm{E}-01$ & $1.00 \mathrm{E}+00$ & 12 & $\begin{array}{l}\text { TTR,SDC4,MOCS2,PNL } \\
\text { IP,AOX1,GC,VNN2,VN } \\
\text { N1,CYB5R3,SLC19A3,L }\end{array}$ \\
\hline
\end{tabular}


bioRxiv preprint doi: https://doi.org/10.1101/2021.03.28.437386; this version posted May 10, 2021. The copyright holder for this preprint (which was not certified by peer review) is the author/funder. All rights reserved. No reuse allowed without permission.

and cofactors

DLR,SLC25A19

1269367

Platelet

$2.59 \mathrm{E}-03$

1.36E-01

9.83E-01

$1.00 \mathrm{E}+00$ degranulatio

n

1269907

SLC-

mediated

9.26E-03

2.80E-01

$1.00 \mathrm{E}+00$

$1.00 \mathrm{E}+00$

transmembra

ne transport

SERPINA1,CLU,FGA,A

LB,APOH,MMRN1,QSO

X1,SERPING1,RARRES 2,ORM1

SLC24A3,ALB, SLC34A

2,CP,SLC17A1,SLCO1A

2,SLC6A20,SLC4A4,SL

C12A7,SLC39A1,SLC28

A3,SLC29A4,SLC38A4,

SLC44A4,SLC16A7

\begin{tabular}{|c|c|c|c|c|c|c|c|}
\hline \multicolumn{8}{|c|}{ Down regulated genes } \\
\hline 1270244 & $\begin{array}{l}\text { Extracellular } \\
\text { matrix } \\
\text { organization }\end{array}$ & $2.05 \mathrm{E}-25$ & $1.40 \mathrm{E}-22$ & $9.91 \mathrm{E}-22$ & $1.40 \mathrm{E}-22$ & 49 & $\begin{array}{c}\text { A2M,PDGFB,PECAM1, } \\
\text { COL22A1,MFAP2,MFA } \\
\text { P4,FBN1,FBN2,COL14A } \\
\text { 1,MMP3,FGG,MMP9,M } \\
\text { MP11,COL1A1,COL1A2 } \\
\text {,COL3A1,COL4A1,COL } \\
\text { 5A1,COL5A2,NID2,COL } \\
\text { 6A2,COL6A3,ITGA11,C } \\
\text { OL12A1,COL15A1,FN1, } \\
\text { ADAMTS2,COL5A3,VC } \\
\text { AN,CTSK,SPARC,ASPN } \\
\text {,LAMA1,P4HA3,BGN,B } \\
\text { MP4,ADAMTS16,NID1, } \\
\text { KDR,CAPN3,DDR2,LA } \\
\text { MA2,LAMA4,TGFB3,T } \\
\text { HBS1,LOX,SERPINE1,L } \\
\text { TBP2,LUM }\end{array}$ \\
\hline 1269010 & $\begin{array}{l}\text { Diseases of } \\
\text { glycosylation }\end{array}$ & $3.76 \mathrm{E}-07$ & 4.27E-05 & 3.03E-04 & $2.56 \mathrm{E}-04$ & 13 & $\begin{array}{c}\text { ADAMTS2,VCAN,MUC } \\
\text { 4,BGN,GPC3,ADAMTS1 } \\
\text { 6,NOTCH3,OMD,ADA } \\
\text { MTS12,THBS1,THBS2, } \\
\text { ADAMTS6,LUM }\end{array}$ \\
\hline 1269350 & $\begin{array}{c}\text { Platelet } \\
\text { activation, } \\
\text { signaling and } \\
\text { aggregation }\end{array}$ & $5.91 \mathrm{E}-06$ & 4.03E-04 & $2.86 \mathrm{E}-03$ & 4.03E-03 & 22 & $\begin{array}{c}\text { A2M,PDGFB,PECAM1, } \\
\text { F2R,FGG,FN1,DGKD,IG } \\
\text { F2,CSF2,SPARC,ISLR,J } \\
\text { AK3,TBXA2R,F2RL3,E } \\
\text { CM1,TGFB3,THBS1,EG } \\
\text { F,TIMP3,SERPINE1,DG } \\
\text { KI,PCDH7 }\end{array}$ \\
\hline 1269340 & Hemostasis & $8.35 \mathrm{E}-05$ & 4.29E-03 & $3.05 \mathrm{E}-02$ & $5.69 \mathrm{E}-02$ & 34 & $\begin{array}{c}\text { A2M,PDGFB,CENPE,PE } \\
\text { CAM1,F2R,PLAT,PLAU } \\
\text {,FGG,KIF6,FN1,DGKD,I } \\
\text { GF2,CSF2,SPARC,GAT } \\
\text { A4,ISLR,CABLES1,JAK } \\
\text { 3,KIF2C,TBXA2R,F2RL } \\
\text { 3,KIF26B,ESAM,ECM1, } \\
\text { TGFB3,THBS1,EGF,GU } \\
\text { CY1A2,TIMP3,SERPINE } \\
\text { 1,DGKI,SLC7A5,PCDH7 } \\
\text {,SERPIND1 }\end{array}$ \\
\hline
\end{tabular}


bioRxiv preprint doi: https://doi.org/10.1101/2021.03.28.437386; this version posted May 10, 2021. The copyright holder for this preprint (which was not certified by peer review) is the author/funder. All rights reserved. No reuse allowed without permission.

\begin{tabular}{|c|c|c|c|c|c|c|c|}
\hline 1270303 & $\begin{array}{c}\text { Axon } \\
\text { guidance }\end{array}$ & $1.66 \mathrm{E}-03$ & $4.51 \mathrm{E}-02$ & $3.20 \mathrm{E}-01$ & $1.00 \mathrm{E}+00$ & 27 & $\begin{array}{c}\text { EPHB6,DOK6,PDGFB,P } \\
\text { DGFRA,SEMA3A,MYL } \\
\text { 9,FGG,MMP9,COL4A1, } \\
\text { COL6A2,COL6A3,FN1, } \\
\text { CSF2,PLXNA4,NRG3,C } \\
\text { HL1,GAP43,LAMA1,DC } \\
\text { X,JAK3,KDR,ST8SIA4, } \\
\text { KIT,UNC5D,EFNA4,EF } \\
\text { NB2,EGF }\end{array}$ \\
\hline 1269592 & $\begin{array}{l}\text { Gastrin- } \\
\text { CREB } \\
\text { signalling } \\
\text { pathway via } \\
\text { PKC and } \\
\text { MAPK }\end{array}$ & $7.76 \mathrm{E}-03$ & $1.82 \mathrm{E}-01$ & $1.00 \mathrm{E}+00$ & $1.00 \mathrm{E}+00$ & 21 & $\begin{array}{c}\text { PDGFB,PDGFRA,F2R,H } \\
\text { RH1,LTB4R,MMP3,FGG } \\
\text {,FN1,DGKD,CSF2,NRG3 } \\
\text {,GHRL,JAK3,KIT,TBXA } \\
\text { 2R,F2RL3,FFAR2,EDNR } \\
\text { A,EGF,LPAR6,DGKI }\end{array}$ \\
\hline
\end{tabular}

Table 5 Topology table for up and down regulated genes

\begin{tabular}{|c|c|c|c|c|c|}
\hline Regulation & Node & Degree & Betweenness & Stress & Closeness \\
\hline Up & JUN & 1596 & 0.297948 & $5.04 \mathrm{E}+08$ & 0.437877 \\
\hline $\mathrm{Up}$ & VCAM1 & 661 & 0.055649 & $1.83 \mathrm{E}+08$ & 0.379038 \\
\hline Up & RELA & 440 & 0.066286 & 65857496 & 0.392096 \\
\hline Up & U2AF2 & 401 & 0.032981 & 50615222 & 0.375241 \\
\hline Up & ADRB2 & 360 & 0.051656 & $1.09 \mathrm{E}+08$ & 0.357594 \\
\hline Up & PPP1CC & 350 & 0.055551 & 48521756 & 0.382627 \\
\hline Up & POLR2A & 320 & 0.042098 & 73677082 & 0.357008 \\
\hline Up & CD81 & 244 & 0.02104 & 53426396 & 0.344262 \\
\hline $\mathrm{Up}$ & SDHA & 228 & 0.023854 & 17009994 & 0.380039 \\
\hline $\mathrm{Up}$ & SNCA & 224 & 0.025545 & 56250412 & 0.341272 \\
\hline Up & ALB & 217 & 0.032126 & 27109520 & 0.350929 \\
\hline Up & ERBB3 & 207 & 0.023464 & 46497836 & 0.338957 \\
\hline $\mathrm{Up}$ & HIF1A & 201 & 0.022327 & 16543606 & 0.372868 \\
\hline Up & OCRL & 183 & 0.021433 & 38355000 & 0.33816 \\
\hline $\mathrm{Up}$ & MRPL12 & 182 & 0.021656 & 24757490 & 0.335917 \\
\hline Up & RAB5C & 164 & 0.019293 & 18077018 & 0.349243 \\
\hline Up & CCDC85B & 148 & 0.026064 & 17688698 & 0.320629 \\
\hline
\end{tabular}




\begin{tabular}{|c|c|c|c|c|c|}
\hline $\mathrm{Up}$ & CLU & 148 & 0.018422 & 34351976 & 0.331337 \\
\hline $\mathrm{Up}$ & FTH1 & 112 & 0.015754 & 15114778 & 0.329531 \\
\hline $\mathrm{Up}$ & TFRC & 110 & 0.016321 & 10628564 & 0.378798 \\
\hline $\mathrm{Up}$ & SPINT2 & 108 & 0.018333 & 13787598 & 0.314599 \\
\hline $\mathrm{Up}$ & MRPL38 & 108 & 0.014795 & 7135306 & 0.347488 \\
\hline Up & CACNA1A & 101 & 0.013778 & 14792904 & 0.318909 \\
\hline $\mathrm{Up}$ & SPP1 & 100 & 0.011753 & 13635028 & 0.324872 \\
\hline Up & GNAI1 & 100 & 0.016452 & 7052876 & 0.346084 \\
\hline Up & PPM1B & 99 & 0.010628 & 13845334 & 0.333148 \\
\hline Up & CHN2 & 94 & 0.003043 & 7480904 & 0.324097 \\
\hline $\mathrm{Up}$ & ZBTB48 & 91 & 0.007794 & 14008360 & 0.306699 \\
\hline Up & ID2 & 88 & 0.008382 & 20399246 & 0.31338 \\
\hline $\mathrm{Up}$ & DUT & 85 & 0.006791 & 9371824 & 0.325667 \\
\hline Up & PGR & 83 & 0.005038 & 6050756 & 0.33088 \\
\hline $\mathrm{Up}$ & TMEM30B & 80 & 0.012048 & 8252762 & 0.301821 \\
\hline Up & HSPA1B & 78 & 0.00697 & 6310746 & 0.350331 \\
\hline $\mathrm{Up}$ & SOD2 & 77 & 0.006883 & 13105960 & 0.314833 \\
\hline $\mathrm{Up}$ & CASP1 & 75 & 0.008457 & 14148852 & 0.309164 \\
\hline Up & STAMBP & 73 & 0.008256 & 8962166 & 0.315013 \\
\hline $\mathrm{Up}$ & NECAB2 & 72 & 0.00898 & 20828314 & 0.294 \\
\hline Up & SOCS1 & 71 & 0.00732 & 4459136 & 0.332855 \\
\hline Up & ATP13A2 & 70 & 0.01148 & 8100584 & 0.311952 \\
\hline $\mathrm{Up}$ & CENPB & 69 & 0.00962 & 5877652 & 0.328913 \\
\hline Up & COX5A & 68 & 0.004787 & 9014728 & 0.310793 \\
\hline Up & PGRMC1 & 67 & 0.005965 & 5851738 & 0.324374 \\
\hline $\mathrm{Up}$ & PFKL & 67 & 0.005301 & 4220404 & 0.339501 \\
\hline Up & ZFP36 & 65 & 0.005869 & 5840334 & 0.325814 \\
\hline Up & SLMAP & 64 & 0.008847 & 14906016 & 0.300925 \\
\hline $\mathrm{Up}$ & KLHL12 & 62 & 0.006002 & 9477918 & 0.31082 \\
\hline $\mathrm{Up}$ & SERPINA1 & 61 & 0.004959 & 3442108 & 0.32758 \\
\hline
\end{tabular}




\begin{tabular}{|c|c|c|c|c|c|}
\hline $\mathrm{Up}$ & CRP & 61 & 0.00901 & 3976752 & 0.320944 \\
\hline $\mathrm{Up}$ & HLA-DRA & 58 & 0.006376 & 6984242 & 0.303374 \\
\hline $\mathrm{Up}$ & SEC24B & 57 & 0.005122 & 7921100 & 0.311736 \\
\hline $\mathrm{Up}$ & HLA-E & 57 & 0.008193 & 5417646 & 0.301114 \\
\hline $\mathrm{Up}$ & RASSF5 & 54 & 0.005973 & 5581726 & 0.309603 \\
\hline Up & CYB5R3 & 53 & 0.005535 & 4457008 & 0.322007 \\
\hline $\mathrm{Up}$ & DUSP1 & 50 & 0.0047 & 10162126 & 0.297576 \\
\hline Up & LYZ & 48 & 0.004406 & 2822858 & 0.352771 \\
\hline Up & DTNB & 46 & 0.006085 & 5998870 & 0.297047 \\
\hline $\mathrm{Up}$ & GBP2 & 46 & 0.002674 & 2254472 & 0.315954 \\
\hline $\mathrm{Up}$ & KYNU & 45 & 0.003541 & 8318140 & 0.294385 \\
\hline Up & ZBTB7A & 44 & 0.003479 & 2378948 & 0.318641 \\
\hline $\mathrm{Up}$ & NUCB1 & 44 & 0.003535 & 3000438 & 0.311156 \\
\hline Up & GABRE & 42 & 0.006362 & 6963592 & 0.273467 \\
\hline $\mathrm{Up}$ & DUSP8 & 42 & 0.003924 & 3730912 & 0.305695 \\
\hline Up & FGA & 41 & 0.002177 & 1408648 & 0.322498 \\
\hline $\mathrm{Up}$ & VNN2 & 39 & 0.004648 & 4918216 & 0.275309 \\
\hline $\mathrm{Up}$ & PIGR & 38 & 0.003219 & 4218970 & 0.283356 \\
\hline Up & CHGB & 37 & 0.002356 & 1883312 & 0.310458 \\
\hline $\mathrm{Up}$ & HLA-DPB1 & 37 & 0.005437 & 4024006 & 0.28368 \\
\hline $\mathrm{Up}$ & MVD & 37 & 0.00277 & 1785902 & 0.307209 \\
\hline $\mathrm{Up}$ & GPAA1 & 36 & 0.006228 & 5917528 & 0.291675 \\
\hline Up & POLD2 & 36 & 0.004619 & 5556090 & 0.301063 \\
\hline $\mathrm{Up}$ & DPP4 & 34 & 0.004172 & 1947850 & 0.298874 \\
\hline $\mathrm{Up}$ & RFX1 & 32 & 0.003758 & 7609514 & 0.295413 \\
\hline Up & EPHX1 & 31 & 0.00324 & 3148816 & 0.29602 \\
\hline Up & ALDOB & 31 & 0.002792 & 2018518 & 0.30784 \\
\hline Up & AGT & 31 & 0.002966 & 1865644 & 0.306294 \\
\hline $\mathrm{Up}$ & PEX7 & 28 & 0.002627 & 7979132 & 0.279546 \\
\hline $\mathrm{Up}$ & MMP1 & 28 & 0.001636 & 962486 & 0.318768 \\
\hline
\end{tabular}




\begin{tabular}{|c|c|c|c|c|c|}
\hline Up & IL6R & 28 & 0.004718 & 1522490 & 0.295316 \\
\hline Up & AK1 & 27 & 0.002177 & 3763326 & 0.290274 \\
\hline Up & $\mathrm{KCNC} 4$ & 27 & 0.002966 & 4065280 & 0.287685 \\
\hline Up & MAF & 26 & 0.001371 & 928624 & 0.315427 \\
\hline Up & LCN2 & 26 & 0.002077 & 4747150 & 0.281902 \\
\hline Up & TRIB2 & 26 & 0.002374 & 1372656 & 0.307157 \\
\hline Up & RNF149 & 26 & 0.003073 & 2741500 & 0.27934 \\
\hline Up & GC & 25 & 0.001091 & 1093748 & 0.300309 \\
\hline Up & BTG1 & 25 & 0.0019 & 963086 & 0.321863 \\
\hline Up & KCNJ8 & 24 & 0.002693 & 1543874 & 0.254755 \\
\hline Up & STS & 23 & 0.002783 & 1476396 & 0.279026 \\
\hline Up & CCDC86 & 23 & $7.45 \mathrm{E}-04$ & 1261094 & 0.295801 \\
\hline Up & UBD & 22 & 0.001864 & 3627404 & 0.290415 \\
\hline Up & $\mathrm{APOH}$ & 22 & $9.68 \mathrm{E}-04$ & 1240028 & 0.29797 \\
\hline Up & $\overline{\mathrm{ABCB} 1}$ & 22 & 0.001386 & 2114132 & 0.29802 \\
\hline Up & RCAN2 & 22 & 0.002346 & 3980546 & 0.273 \\
\hline Up & DEPTOR & 22 & 0.001221 & 937788 & 0.307538 \\
\hline $\mathrm{Up}$ & BTG2 & 20 & $6.52 \mathrm{E}-04$ & 1046918 & 0.283703 \\
\hline Up & ARVCF & 19 & 0.002101 & 909702 & 0.281471 \\
\hline $\mathrm{Up}$ & AMBP & 17 & $7.00 \mathrm{E}-04$ & 525586 & 0.31932 \\
\hline Up & CXCL2 & 17 & $9.45 \mathrm{E}-04$ & 498648 & 0.305228 \\
\hline Up & MMRN1 & 17 & $4.60 \mathrm{E}-04$ & 617814 & 0.267011 \\
\hline Up & FAM193B & 17 & 0.001148 & 1447216 & 0.291699 \\
\hline Up & HLA-B & 16 & 0.001753 & 1709356 & 0.316705 \\
\hline Up & GCG & 16 & 0.001734 & 1201492 & 0.270831 \\
\hline Up & ANG & 15 & 0.001061 & 1182188 & 0.286699 \\
\hline Up & RIPPLY2 & 13 & $6.72 \mathrm{E}-04$ & 1051108 & 0.249022 \\
\hline Up & CDKN2A & 11 & $7.57 \mathrm{E}-04$ & 1062712 & 0.32113 \\
\hline Up & PDK4 & 11 & $5.73 \mathrm{E}-04$ & 839962 & 0.257952 \\
\hline Up & PENK & 10 & 0.001694 & 1717524 & 0.24922 \\
\hline
\end{tabular}




\begin{tabular}{|c|c|c|c|c|c|}
\hline $\mathrm{Up}$ & MAN1A1 & 10 & $3.87 \mathrm{E}-04$ & 238680 & 0.259994 \\
\hline $\mathrm{Up}$ & GAMT & 9 & $3.76 \mathrm{E}-04$ & 408938 & 0.279872 \\
\hline $\mathrm{Up}$ & CYP3A5 & 8 & 0.001126 & 1514978 & 0.241538 \\
\hline $\mathrm{Up}$ & AOX1 & 8 & $2.93 \mathrm{E}-04$ & 399780 & 0.258536 \\
\hline $\mathrm{Up}$ & HLA-DRB 1 & 7 & $1.24 \mathrm{E}-04$ & 74760 & 0.250776 \\
\hline Up & HLA-A & 7 & $7.84 \mathrm{E}-04$ & 861244 & 0.28934 \\
\hline $\mathrm{Up}$ & RAB33A & 7 & 5.82E-04 & 1629132 & 0.221958 \\
\hline Up & LONP1 & 6 & $5.55 \mathrm{E}-04$ & 2034278 & 0.328373 \\
\hline Up & HLA-H & 6 & $1.96 \mathrm{E}-04$ & 63810 & 0.271086 \\
\hline Up & MAP3K9 & 6 & $2.80 \mathrm{E}-04$ & 523732 & 0.268857 \\
\hline $\mathrm{Up}$ & ALDH2 & 5 & $2.38 \mathrm{E}-04$ & 448744 & 0.310928 \\
\hline Up & HLA-C & 5 & 4.48E-04 & 299492 & 0.271342 \\
\hline $\mathrm{Up}$ & NR4A1 & 5 & $1.74 \mathrm{E}-04$ & 265578 & 0.298378 \\
\hline Up & CARTPT & 5 & $3.33 \mathrm{E}-04$ & 343864 & 0.26055 \\
\hline $\mathrm{Up}$ & APOL1 & 4 & $1.94 \mathrm{E}-05$ & 34026 & 0.25131 \\
\hline Up & TBL2 & 4 & 7.27E-04 & 1174624 & 0.311925 \\
\hline $\mathrm{Up}$ & TTR & 4 & $5.60 \mathrm{E}-04$ & 453308 & 0.270913 \\
\hline $\mathrm{Up}$ & CD74 & 4 & $2.05 \mathrm{E}-04$ & 127222 & 0.259189 \\
\hline Up & CPM & 4 & 5.33E-04 & 590954 & 0.28459 \\
\hline $\mathrm{Up}$ & TMEM176A & 4 & $2.82 \mathrm{E}-04$ & 303148 & 0.244104 \\
\hline Up & HAO1 & 4 & $3.12 \mathrm{E}-04$ & 1039252 & 0.250113 \\
\hline $\mathrm{Up}$ & CHCHD10 & 3 & $4.87 \mathrm{E}-05$ & 78354 & 0.27908 \\
\hline $\mathrm{Up}$ & SUCLG2 & 3 & $8.47 \mathrm{E}-05$ & 93604 & 0.283569 \\
\hline $\mathrm{Up}$ & CTSD & 3 & $4.02 \mathrm{E}-05$ & 270406 & 0.307314 \\
\hline $\mathrm{Up}$ & DDX54 & 3 & $6.87 \mathrm{E}-05$ & 270908 & 0.307341 \\
\hline Up & ANP32A & 3 & $2.05 \mathrm{E}-05$ & 65462 & 0.310753 \\
\hline $\mathrm{Up}$ & BIRC3 & 3 & 5.17E-05 & 155646 & 0.286608 \\
\hline $\mathrm{Up}$ & GIGYF1 & 2 & $5.44 \mathrm{E}-06$ & 14190 & 0.272638 \\
\hline $\mathrm{Up}$ & RTN1 & 2 & $1.68 \mathrm{E}-05$ & 23170 & 0.266921 \\
\hline $\mathrm{Up}$ & SERPING1 & 2 & $2.26 \mathrm{E}-05$ & 9370 & 0.261051 \\
\hline
\end{tabular}


bioRxiv preprint doi: https://doi.org/10.1101/2021.03.28.437386; this version posted May 10, 2021. The copyright holder for this preprint (which was not certified by peer review) is the author/funder. All rights reserved. No reuse allowed without permission.

\begin{tabular}{|c|c|c|c|c|c|}
\hline Up & SERPINE2 & 2 & 2.62E-06 & 672 & 0.246784 \\
\hline Up & TRAPPC5 & 2 & $6.26 \mathrm{E}-05$ & 68134 & 0.249861 \\
\hline Up & APCS & 2 & 0 & 0 & 0.295158 \\
\hline Up & SERPINA6 & 2 & $3.33 \mathrm{E}-04$ & 309232 & 0.296276 \\
\hline Up & REG3A & 2 & $1.52 \mathrm{E}-05$ & 52952 & 0.299908 \\
\hline Up & BBC3 & 2 & 0 & 0 & 0.259778 \\
\hline Up & RPRD1A & 2 & $3.92 \mathrm{E}-05$ & 277120 & 0.309669 \\
\hline Up & DACH1 & 2 & 0 & 0 & 0.309936 \\
\hline Up & RGS4 & 2 & $5.44 \mathrm{E}-05$ & 21664 & 0.272307 \\
\hline Up & CASP10 & 2 & $3.66 \mathrm{E}-05$ & 73078 & 0.264702 \\
\hline Up & PPARA & 2 & $3.08 \mathrm{E}-05$ & 28360 & 0.285403 \\
\hline Up & DHCR24 & 2 & $2.06 \mathrm{E}-05$ & 30004 & 0.275109 \\
\hline Up & RAP1A & 2 & $3.50 \mathrm{E}-05$ & 22882 & 0.262835 \\
\hline Up & PCDH10 & 2 & $6.75 \mathrm{E}-06$ & 11790 & 0.233911 \\
\hline Up & F10 & 2 & $2.24 \mathrm{E}-06$ & 2690 & 0.247787 \\
\hline Up & PSMG1 & 2 & 0 & 0 & 0.29646 \\
\hline Up & CFB & 2 & 0 & 0 & 0.297072 \\
\hline Up & PPP1R12B & 2 & $1.19 \mathrm{E}-05$ & 11496 & 0.250122 \\
\hline Up & ABLIM1 & 2 & $4.21 \mathrm{E}-05$ & 35910 & 0.250479 \\
\hline Up & LTBP3 & 1 & 0 & 0 & 0.241806 \\
\hline Up & NAT9 & 1 & 0 & 0 & 0.267189 \\
\hline Up & GGA1 & 1 & 0 & 0 & 0.229025 \\
\hline Up & PJA1 & 1 & 0 & 0 & 0.239559 \\
\hline Up & SERPINA10 & 1 & 0 & 0 & 0.240834 \\
\hline Up & RNF32 & 1 & 0 & 0 & 0.249376 \\
\hline Up & HLA-DMB & 1 & 0 & 0 & 0.232768 \\
\hline Up & SAA1 & 1 & 0 & 0 & 0.241757 \\
\hline Up & C4BPA & 1 & 0 & 0 & 0.294264 \\
\hline Up & GABBR1 & 1 & 0 & 0 & 0.259778 \\
\hline Up & GET4 & 1 & 0 & 0 & 0.239455 \\
\hline
\end{tabular}


bioRxiv preprint doi: https://doi.org/10.1101/2021.03.28.437386; this version posted May 10, 2021. The copyright holder for this preprint (which was not certified by peer review) is the author/funder. All rights reserved. No reuse allowed without permission.

\begin{tabular}{|c|c|c|c|c|c|}
\hline Up & MUC20 & 1 & 0 & 0 & 0.235388 \\
\hline Up & NUDT16 & 1 & 0 & 0 & 0.304543 \\
\hline Up & ITPK1 & 1 & 0 & 0 & 0.304543 \\
\hline Up & FIGNL1 & 1 & 0 & 0 & 0.304543 \\
\hline Up & SLC25A19 & 1 & 0 & 0 & 0.304543 \\
\hline Up & RAP1GAP & 1 & 0 & 0 & 0.282411 \\
\hline Up & RPS6KA6 & 1 & 0 & 0 & 0.247514 \\
\hline Up & ARRDC4 & 1 & 0 & 0 & 0.263412 \\
\hline Up & RAB27A & 1 & 0 & 0 & 0.263412 \\
\hline Up & SPOCK3 & 1 & 0 & 0 & 0.236807 \\
\hline Up & DENND2D & 1 & 0 & 0 & 0.25945 \\
\hline Up & FAM20A & 1 & 0 & 0 & 0.245219 \\
\hline Up & TXNDC11 & 1 & 0 & 0 & 0.248884 \\
\hline $\mathrm{Up}$ & CCL20 & 1 & 0 & 0 & 0.219681 \\
\hline Up & HLA-F & 1 & 0 & 0 & 0.231435 \\
\hline Up & LRRC24 & 1 & 0 & 0 & 0.231435 \\
\hline Up & BCS1L & 1 & 0 & 0 & 0.274867 \\
\hline Up & MACROD1 & 1 & 0 & 0 & 0.274867 \\
\hline Up & KDM1B & 1 & 0 & 0 & 0.237111 \\
\hline Up & WFDC2 & 1 & 0 & 0 & 0.24227 \\
\hline Up & SLC25A36 & 1 & 0 & 0 & 0.24227 \\
\hline Up & PTPRH & 1 & 0 & 0 & 0.253159 \\
\hline Up & ELL & 1 & 0 & 0 & 0.263094 \\
\hline Up & XAB2 & 1 & 0 & 0 & 0.263094 \\
\hline Up & MTMR12 & 1 & 0 & 0 & 0.229339 \\
\hline Up & PPP1R1B & 1 & 0 & 0 & 0.27675 \\
\hline Up & POLD3 & 1 & 0 & 0 & 0.231405 \\
\hline Up & LSM6 & 1 & 0 & 0 & 0.231405 \\
\hline Up & MUC13 & 1 & 0 & 0 & 0.258853 \\
\hline Up & C1orf122 & 1 & 0 & 0 & 0.25146 \\
\hline
\end{tabular}


bioRxiv preprint doi: https://doi.org/10.1101/2021.03.28.437386; this version posted May 10, 2021. The copyright holder for this preprint (which was not certified by peer review) is the author/funder. All rights reserved. No reuse allowed without permission.

\begin{tabular}{|c|c|c|c|c|c|}
\hline Up & SLC22A17 & 1 & 0 & 0 & 0.219916 \\
\hline Up & NR1H4 & 1 & 0 & 0 & 0.28167 \\
\hline Up & ITGB3BP & 1 & 0 & 0 & 0.28167 \\
\hline Up & PTPRN2 & 1 & 0 & 0 & 0.245663 \\
\hline Up & ZC3H12A & 1 & 0 & 0 & 0.271608 \\
\hline Up & TMEM143 & 1 & 0 & 0 & 0.231853 \\
\hline Up & FAM8A1 & 1 & 0 & 0 & 0.237785 \\
\hline Up & QSOX1 & 1 & 0 & 0 & 0.242974 \\
\hline Up & LDLR & 1 & 0 & 0 & 0.229574 \\
\hline Up & LRG1 & 1 & 0 & 0 & 0.294264 \\
\hline Up & ORM1 & 1 & 0 & 0 & 0.259778 \\
\hline Up & CA2 & 1 & 0 & 0 & 0.304543 \\
\hline Up & OIP5 & 1 & 0 & 0 & 0.304543 \\
\hline Up & IMPA2 & 1 & 0 & 0 & 0.245671 \\
\hline Up & SDC4 & 1 & 0 & 0 & 0.252041 \\
\hline Up & GCNT3 & 1 & 0 & 0 & 0.252041 \\
\hline Up & MT1A & 1 & 0 & 0 & 0.257113 \\
\hline Up & FFAR1 & 1 & 0 & 0 & 0.257113 \\
\hline Up & CEBPD & 1 & 0 & 0 & 0.28167 \\
\hline Up & CA12 & 1 & 0 & 0 & 0.231853 \\
\hline Up & ADORA2A & 1 & 0 & 0 & 0.22721 \\
\hline Up & DOCK8 & 1 & 0 & 0 & 0.257888 \\
\hline Up & STX19 & 1 & 0 & 0 & 0.230169 \\
\hline Up & TRIOBP & 1 & 0 & 0 & 0.242237 \\
\hline Up & CACNA1H & 1 & 0 & 0 & 0.220929 \\
\hline Up & SLC39A1 & 1 & 0 & 0 & 0.239591 \\
\hline Up & P4HA1 & 1 & 0 & 0 & 0.234338 \\
\hline Down & FN1 & 800 & 0.121948 & $1.77 \mathrm{E}+08$ & 0.416937 \\
\hline Down & CDK1 & 321 & 0.052371 & 37130306 & 0.393533 \\
\hline Down & TK1 & 183 & 0.028359 & 22061908 & 0.356407 \\
\hline
\end{tabular}


bioRxiv preprint doi: https://doi.org/10.1101/2021.03.28.437386; this version posted May 10, 2021. The copyright holder for this preprint (which was not certified by peer review) is the author/funder. All rights reserved. No reuse allowed without permission.

\begin{tabular}{|c|c|c|c|c|c|}
\hline Down & A2M & 165 & 0.021657 & 31093610 & 0.33221 \\
\hline Down & ACTA2 & 156 & 0.021508 & 16177182 & 0.356813 \\
\hline Down & ANLN & 147 & 0.012288 & 32652030 & 0.31966 \\
\hline Down & RPTOR & 138 & 0.015393 & 20848032 & 0.33123 \\
\hline Down & FLNC & 130 & 0.020359 & 9885742 & 0.364849 \\
\hline Down & MME & 124 & 0.01613 & 22827922 & 0.327014 \\
\hline Down & CHEK1 & 123 & 0.0138 & 9428096 & 0.36459 \\
\hline Down & MCM6 & 119 & 0.012797 & 10240308 & 0.34408 \\
\hline Down & HEY1 & 115 & 0.007467 & 26394370 & 0.324521 \\
\hline Down & TOP2A & 113 & 0.00822 & 7037480 & 0.366131 \\
\hline Down & PTN & 109 & 0.01344 & 17516900 & 0.319717 \\
\hline Down & RIPK3 & 109 & 0.005618 & 13238646 & 0.329395 \\
\hline Down & KIT & 105 & 0.00936 & 8415988 & 0.318274 \\
\hline Down & BUB1 & 102 & 0.012926 & 9378750 & 0.327669 \\
\hline Down & IGF2BP3 & 101 & 0.006201 & 5000402 & 0.358021 \\
\hline Down & CDH5 & 97 & 0.014275 & 14697350 & 0.31753 \\
\hline Down & STIL & 94 & 0.010914 & 12929196 & 0.315912 \\
\hline Down & JAK3 & 93 & 0.006847 & 6645686 & 0.330743 \\
\hline Down & TUBB2B & 89 & 0.011127 & 6631350 & 0.358521 \\
\hline Down & CXCR4 & 82 & 0.010003 & 6983362 & 0.336956 \\
\hline Down & ALK & 79 & 0.006945 & 9288848 & 0.319235 \\
\hline Down & COL1A1 & 78 & 0.007539 & 4482218 & 0.336184 \\
\hline Down & KIF2C & 78 & 0.00852 & 6501484 & 0.336909 \\
\hline Down & NOTCH3 & 78 & 0.010163 & 11236576 & 0.315068 \\
\hline Down & CDC6 & 74 & 0.00694 & 5538892 & 0.323892 \\
\hline Down & UBE2C & 69 & 0.00668 & 5381164 & 0.318429 \\
\hline Down & ST8SIA4 & 68 & 0.011163 & 8424288 & 0.30563 \\
\hline Down & EPPK1 & 68 & 0.004854 & 7870332 & 0.320301 \\
\hline Down & NES & 63 & 0.005965 & 5426230 & 0.324301 \\
\hline Down & GRIP1 & 61 & 0.006138 & 14613812 & 0.304595 \\
\hline
\end{tabular}




\begin{tabular}{|c|c|c|c|c|c|}
\hline Down & LEF1 & 60 & 0.005343 & 4927416 & 0.310793 \\
\hline Down & MMP9 & 60 & 0.006943 & 5669948 & 0.345071 \\
\hline Down & THBS1 & 57 & 0.003128 & 2389380 & 0.326747 \\
\hline Down & COL1A2 & 48 & 0.003029 & 1783500 & 0.32932 \\
\hline Down & TPX2 & 46 & 0.003701 & 1798214 & 0.340352 \\
\hline Down & KRT17 & 45 & 0.003227 & 3063576 & 0.325652 \\
\hline Down & CENPE & 43 & 0.003357 & 2673372 & 0.310807 \\
\hline Down & TRIM9 & 43 & 0.004332 & 4076190 & 0.298973 \\
\hline Down & PLAT & 42 & 0.004548 & 2384326 & 0.317222 \\
\hline Down & NEXN & 40 & 0.002111 & 1827254 & 0.320901 \\
\hline Down & ARG1 & 39 & 0.003041 & 4412562 & 0.305942 \\
\hline Down & PTGS2 & 39 & 0.002083 & 2565408 & 0.316649 \\
\hline Down & PCDH7 & 38 & 0.004648 & 3503260 & 0.300108 \\
\hline Down & TFF1 & 38 & 0.002965 & 1245772 & 0.334139 \\
\hline Down & FGG & 37 & 0.002101 & 1367870 & 0.309656 \\
\hline Down & HMGA2 & 36 & $9.38 \mathrm{E}-04$ & 969146 & 0.320587 \\
\hline Down & LCP1 & 35 & 0.002865 & 1240328 & 0.343735 \\
\hline Down & COL5A1 & 34 & 0.001354 & 878512 & 0.318627 \\
\hline Down & MMP3 & 34 & 0.002251 & 1415208 & 0.31027 \\
\hline Down & ASB9 & 34 & 0.001201 & 3273876 & 0.29823 \\
\hline Down & COL6A2 & 33 & 0.003726 & 2359320 & 0.308699 \\
\hline Down & IL16 & 33 & 0.003152 & 1947338 & 0.313625 \\
\hline Down & PRC1 & 32 & 0.002506 & 1394808 & 0.310378 \\
\hline Down & SPARC & 32 & 0.00126 & 838072 & 0.31898 \\
\hline Down & NETO2 & 32 & 0.003703 & 1704326 & 0.304298 \\
\hline Down & LOX & 32 & 0.001666 & 910394 & 0.322152 \\
\hline Down & CDKN3 & 32 & 0.003019 & 1564204 & 0.302991 \\
\hline Down & COL4A1 & 31 & 0.001704 & 998644 & 0.318825 \\
\hline Down & VCAN & 31 & 0.002243 & 3325576 & 0.281515 \\
\hline Down & TNFAIP6 & 29 & 0.004894 & 3551464 & 0.309031 \\
\hline
\end{tabular}




\begin{tabular}{|c|c|c|c|c|c|}
\hline Down & BMP4 & 29 & 0.00477 & 6323086 & 0.261868 \\
\hline Down & DCAF4 & 29 & 0.002018 & 6457740 & 0.29138 \\
\hline Down & DACT1 & 28 & 0.001674 & 1236348 & 0.321216 \\
\hline Down & FBN2 & 27 & 0.002317 & 1481936 & 0.317068 \\
\hline Down & FBN1 & 27 & 0.001379 & 1080758 & 0.307209 \\
\hline Down & CPA4 & 27 & 0.002556 & 996084 & 0.289201 \\
\hline Down & PXDN & 26 & 0.002559 & 2031162 & 0.300221 \\
\hline Down & CNN1 & 24 & 0.002226 & 1637732 & 0.325932 \\
\hline Down & GAP43 & 24 & 0.00294 & 1612258 & 0.325343 \\
\hline Down & FAT3 & 23 & 0.002598 & 2919422 & 0.275457 \\
\hline Down & KIF26B & 22 & 0.001863 & 792688 & 0.306372 \\
\hline Down & CYBRD1 & 22 & 0.001123 & 1561118 & 0.291533 \\
\hline Down & LRRC8E & 22 & 0.001826 & 2528860 & 0.287639 \\
\hline Down & SIX2 & 22 & 0.001973 & 2753556 & 0.291415 \\
\hline Down & POU2F2 & 21 & 0.001426 & 1334750 & 0.295316 \\
\hline Down & FLI1 & 21 & 0.00112 & 2415044 & 0.285052 \\
\hline Down & GPR161 & 20 & 0.002009 & 2695240 & 0.292303 \\
\hline Down & PCDH12 & 19 & 0.001536 & 1167904 & 0.272989 \\
\hline Down & ADAMTS2 & 19 & 0.002709 & 2167276 & 0.259404 \\
\hline Down & ANKRD1 & 19 & 0.001457 & 2414200 & 0.271906 \\
\hline Down & TEKT2 & 19 & 0.002071 & 3016046 & 0.282477 \\
\hline Down & COLQ & 18 & 0.003044 & 3000882 & 0.306046 \\
\hline Down & MSRB3 & 18 & 0.002113 & 3276728 & 0.289003 \\
\hline Down & CSF2 & 17 & $1.81 \mathrm{E}-04$ & 232386 & 0.284073 \\
\hline Down & INHBE & 17 & 0.001905 & 3619024 & 0.291805 \\
\hline Down & NTM & 17 & 0.001536 & 2018548 & 0.280112 \\
\hline Down & SULF2 & 16 & 0.001763 & 1637484 & 0.282677 \\
\hline Down & ADAMTS12 & 14 & $3.95 \mathrm{E}-04$ & 228572 & 0.287916 \\
\hline Down & CABLES1 & 14 & $4.83 \mathrm{E}-04$ & 277378 & 0.300472 \\
\hline Down & KANK4 & 14 & 0.002325 & 3632254 & 0.267836 \\
\hline
\end{tabular}




\begin{tabular}{|c|c|c|c|c|c|}
\hline Down & EBF1 & 14 & 0.001351 & 2657292 & 0.252404 \\
\hline Down & TGFBI & 13 & $4.16 \mathrm{E}-04$ & 410792 & 0.302748 \\
\hline Down & CLIC5 & 13 & $6.32 \mathrm{E}-04$ & 350440 & 0.308236 \\
\hline Down & KLRK1 & 13 & 0.001636 & 1607184 & 0.253865 \\
\hline Down & SLC16A10 & 13 & 0.002048 & 1684164 & 0.231182 \\
\hline Down & KLHL1 & 12 & $8.40 \mathrm{E}-04$ & 685122 & 0.283569 \\
\hline Down & ULBP1 & 11 & 0.001627 & 1909902 & 0.252616 \\
\hline Down & CENPL & 11 & 0.001015 & 1075848 & 0.281835 \\
\hline Down & EFNA4 & 10 & 0.001001 & 1689268 & 0.262691 \\
\hline Down & SGCD & 10 & 0.001345 & 549950 & 0.269018 \\
\hline Down & TNFRSF11B & 8 & $8.96 \mathrm{E}-04$ & 1069060 & 0.296057 \\
\hline Down & ERG & 8 & $9.91 \mathrm{E}-04$ & 1598524 & 0.326955 \\
\hline Down & PDGFB & 8 & $2.27 \mathrm{E}-04$ & 209072 & 0.266763 \\
\hline Down & GPX8 & 8 & $9.35 \mathrm{E}-04$ & 811058 & 0.233017 \\
\hline Down & ADORA2B & 7 & $8.76 \mathrm{E}-04$ & 1026210 & 0.25586 \\
\hline Down & POSTN & 6 & $8.80 \mathrm{E}-04$ & 1154784 & 0.237699 \\
\hline Down & KIF6 & 6 & $8.38 \mathrm{E}-04$ & 1734970 & 0.202506 \\
\hline Down & HLA-DQB1 & 5 & $3.89 \mathrm{E}-04$ & 258228 & 0.235782 \\
\hline Down & NTNG2 & 5 & $1.04 \mathrm{E}-04$ & 119956 & 0.2581 \\
\hline Down & HHATL & 4 & $3.03 \mathrm{E}-04$ & 173754 & 0.247812 \\
\hline Down & SRPX2 & 4 & $1.18 \mathrm{E}-05$ & 10068 & 0.23472 \\
\hline Down & TIMP3 & 4 & $2.01 \mathrm{E}-04$ & 158044 & 0.310097 \\
\hline Down & HCST & 4 & $2.61 \mathrm{E}-04$ & 63872 & 0.273894 \\
\hline Down & TCF7L1 & 4 & $1.72 \mathrm{E}-05$ & 21986 & 0.253936 \\
\hline Down & ZBTB47 & 4 & $2.82 \mathrm{E}-04$ & 354140 & 0.266063 \\
\hline Down & SALL4 & 4 & $1.14 \mathrm{E}-05$ & 20262 & 0.267368 \\
\hline Down & CST6 & 3 & $5.80 \mathrm{E}-05$ & 89820 & 0.250776 \\
\hline Down & LAMA1 & 3 & $6.11 \mathrm{E}-05$ & 12132 & 0.257601 \\
\hline Down & NID1 & 3 & $4.30 \mathrm{E}-06$ & 4204 & 0.258499 \\
\hline Down & BGN & 3 & $8.53 \mathrm{E}-05$ & 103066 & 0.254728 \\
\hline
\end{tabular}


bioRxiv preprint doi: https://doi.org/10.1101/2021.03.28.437386; this version posted May 10, 2021. The copyright holder for this preprint (which was not certified by peer review) is the author/funder. All rights reserved. No reuse allowed without permission.

\begin{tabular}{|c|c|c|c|c|c|}
\hline Down & PDGFRA & 3 & $7.58 \mathrm{E}-05$ & 77934 & 0.284916 \\
\hline Down & COL3A1 & 3 & $1.64 \mathrm{E}-06$ & 1006 & 0.253096 \\
\hline Down & $\mathrm{ADA}$ & 3 & $3.21 \mathrm{E}-05$ & 15284 & 0.235058 \\
\hline Down & NELL2 & 2 & $2.10 \mathrm{E}-05$ & 14054 & 0.246513 \\
\hline Down & KDR & 2 & 2.89E-05 & 27088 & 0.254746 \\
\hline Down & ECEL1 & 2 & $4.32 \mathrm{E}-05$ & 24446 & 0.234537 \\
\hline Down & STAMBPL1 & 2 & $4.96 \mathrm{E}-05$ & 27352 & 0.254268 \\
\hline Down & SERPINE1 & 2 & $2.85 \mathrm{E}-06$ & 2312 & 0.251741 \\
\hline Down & CD93 & 2 & 0 & 0 & 0.253811 \\
\hline Down & ZNF16 & 2 & 0 & 0 & 0.253811 \\
\hline Down & NID2 & 2 & $1.07 \mathrm{E}-06$ & 1590 & 0.25443 \\
\hline Down & IGDCC4 & 2 & $1.01 \mathrm{E}-04$ & 72314 & 0.262566 \\
\hline Down & ECM1 & 2 & $4.51 \mathrm{E}-06$ & 13198 & 0.248764 \\
\hline Down & F2R & 2 & $2.19 \mathrm{E}-05$ & 6442 & 0.256902 \\
\hline Down & ASPM & 2 & $1.17 \mathrm{E}-04$ & 27730 & 0.255107 \\
\hline Down & THBS2 & 2 & 0 & 0 & 0.264556 \\
\hline Down & COL5A3 & 2 & 0 & 0 & 0.251187 \\
\hline Down & GREM2 & 2 & $1.13 \mathrm{E}-06$ & 1018 & 0.207542 \\
\hline Down & COL14A1 & 2 & $3.69 \mathrm{E}-05$ & 13532 & 0.278335 \\
\hline Down & GLRA1 & 2 & 0 & 0 & 0 \\
\hline Down & LDHAL6A & 2 & $8.46 \mathrm{E}-06$ & 18176 & 0.280834 \\
\hline Down & MFAP2 & 2 & 0 & 0 & 0.242474 \\
\hline Down & MST1R & 2 & $2.48 \mathrm{E}-05$ & 76094 & 0.293269 \\
\hline Down & FOXQ1 & 2 & $2.41 \mathrm{E}-06$ & 5328 & 0.256728 \\
\hline Down & PRR11 & 2 & $3.99 \mathrm{E}-06$ & 4210 & 0.259441 \\
\hline Down & PLAU & 2 & $3.89 \mathrm{E}-06$ & 3598 & 0.246159 \\
\hline Down & RGS5 & 2 & $3.15 \mathrm{E}-05$ & 39976 & 0.279535 \\
\hline Down & HCLS1 & 2 & $1.38 \mathrm{E}-05$ & 64778 & 0.279764 \\
\hline Down & RASSF9 & 2 & 0 & 0 & 0.279275 \\
\hline Down & CAPN3 & 2 & $1.29 \mathrm{E}-04$ & 71456 & 0.26935 \\
\hline
\end{tabular}


bioRxiv preprint doi: https://doi.org/10.1101/2021.03.28.437386; this version posted May 10, 2021. The copyright holder for this preprint (which was not certified by peer review) is the author/funder. All rights reserved. No reuse allowed without permission.

\begin{tabular}{|c|c|c|c|c|c|}
\hline Down & EMCN & 2 & $3.95 \mathrm{E}-06$ & 4814 & 0.206713 \\
\hline Down & PTPRE & 1 & 0 & 0 & 0.244935 \\
\hline Down & GHR & 1 & 0 & 0 & 0.24974 \\
\hline Down & KIF14 & 1 & 0 & 0 & 0.23932 \\
\hline Down & FRMD5 & 1 & 0 & 0 & 0.23932 \\
\hline Down & TBC1D2 & 1 & 0 & 0 & 0.246809 \\
\hline Down & MMP11 & 1 & 0 & 0 & 0.246758 \\
\hline Down & ENPEP & 1 & 0 & 0 & 0.234483 \\
\hline Down & NGF & 1 & 0 & 0 & 0.249376 \\
\hline Down & DDR2 & 1 & 0 & 0 & 0.251609 \\
\hline Down & AMPD3 & 1 & 0 & 0 & 0.259778 \\
\hline Down & KRT6B & 1 & 0 & 0 & 0.259778 \\
\hline Down & PALMD & 1 & 0 & 0 & 0.304543 \\
\hline Down & BACH2 & 1 & 0 & 0 & 0.304543 \\
\hline Down & NOX5 & 1 & 0 & 0 & 0.304543 \\
\hline Down & USP6 & 1 & 0 & 0 & 0.304543 \\
\hline Down & MCAM & 1 & 0 & 0 & 0.263412 \\
\hline Down & LUM & 1 & 0 & 0 & 0.247744 \\
\hline Down & CTSK & 1 & 0 & 0 & 0.241847 \\
\hline Down & CMTM3 & 1 & 0 & 0 & 0.245219 \\
\hline Down & FAT4 & 1 & 0 & 0 & 0.248884 \\
\hline Down & COL12A1 & 1 & 0 & 0 & 0.256554 \\
\hline Down & ACSM3 & 1 & 0 & 0 & 0.274867 \\
\hline Down & LAMA4 & 1 & 0 & 0 & 0.24227 \\
\hline Down & PHLDA1 & 1 & 0 & 0 & 0.253159 \\
\hline Down & ZNF74 & 1 & 0 & 0 & 0.263094 \\
\hline Down & NLRP1 & 1 & 0 & 0 & 0.236161 \\
\hline Down & IL18 & 1 & 0 & 0 & 0.236161 \\
\hline Down & MFAP4 & 1 & 0 & 0 & 0.235019 \\
\hline Down & APOBEC3B & 1 & 0 & 0 & 0.27675 \\
\hline
\end{tabular}


bioRxiv preprint doi: https://doi.org/10.1101/2021.03.28.437386; this version posted May 10, 2021. The copyright holder for this preprint (which was not certified by peer review) is the author/funder. All rights reserved. No reuse allowed without permission.

\begin{tabular}{|c|c|c|c|c|c|}
\hline Down & SPOCD1 & 1 & 0 & 0 & 0.27675 \\
\hline Down & GPRC5A & 1 & 0 & 0 & 0.258853 \\
\hline Down & E2F7 & 1 & 0 & 0 & 0.244776 \\
\hline Down & NRG3 & 1 & 0 & 0 & 0.205779 \\
\hline Down & S1PR3 & 1 & 0 & 0 & 0.257113 \\
\hline Down & TAF4B & 1 & 0 & 0 & 0.28167 \\
\hline Down & NRBP2 & 1 & 0 & 0 & 0.238756 \\
\hline Down & SYNPO2 & 1 & 0 & 0 & 0.267328 \\
\hline Down & MMS22L & 1 & 0 & 0 & 0.256006 \\
\hline Down & TIPIN & 1 & 0 & 0 & 0.256006 \\
\hline Down & ACOX2 & 1 & 0 & 0 & 0.231323 \\
\hline Down & CCNJL & 1 & 0 & 0 & 0.240079 \\
\hline Down & ZNF564 & 1 & 0 & 0 & 0.242793 \\
\hline Down & COLEC11 & 1 & 0 & 0 & 0.24466 \\
\hline Down & RTEL1 & 1 & 0 & 0 & 0.237785 \\
\hline Down & CHL1 & 1 & 0 & 0 & 0.304543 \\
\hline Down & BCAS1 & 1 & 0 & 0 & 0.304543 \\
\hline Down & $\overline{D C X}$ & 1 & 0 & 0 & 0.245219 \\
\hline Down & COL6A3 & 1 & 0 & 0 & 0.241643 \\
\hline Down & EGF & 1 & 0 & 0 & 0.253159 \\
\hline Down & ZSCAN20 & 1 & 0 & 0 & 0.242605 \\
\hline Down & IFITM1 & 1 & 0 & 0 & 0.256106 \\
\hline Down & STK10 & 1 & 0 & 0 & 0.256106 \\
\hline Down & HRH1 & 1 & 0 & 0 & 0.256106 \\
\hline Down & PECAM1 & 1 & 0 & 0 & 0.252041 \\
\hline Down & PCK1 & 1 & 0 & 0 & 0.257113 \\
\hline Down & S1PR1 & 1 & 0 & 0 & 0.257113 \\
\hline Down & MYL9 & 1 & 0 & 0 & 0.252714 \\
\hline Down & SLC7A5 & 1 & 0 & 0 & 0.252714 \\
\hline Down & GATA4 & 1 & 0 & 0 & 0.238613 \\
\hline
\end{tabular}




\begin{tabular}{cccccc}
\hline Down & RASSF2 & 1 & 0 & 0.236417 & 0 \\
\hline Down & CDCA7L & 1 & 0 & 0.24466 \\
\hline Down & ISLR & 1 & 0 & 0.24466 \\
\hline Down & GPC3 & 1 & 0 & 0.201677 \\
\hline Down & EFNB2 & 1 & 0 & 0 \\
\hline Down & HEY2 & 1 & 0 & 0.233486 \\
\hline
\end{tabular}

Table 6 miRNA - hub gene and TF - hub gene interaction

\begin{tabular}{|c|c|c|c|c|c|c|c|}
\hline Regulation & Hub Genes & Degree & MicroRNA & Regulation & Hub Genes & Degree & TF \\
\hline Up & MRPL12 & 102 & hsa-mir-1255b-5p & Up & JUN & 62 & VDR \\
\hline Up & RAB5C & 100 & hsa-mir-499a-5p & Up & POLR2A & 45 & BACH1 \\
\hline Up & VCAM1 & 86 & hsa-mir-200a-3p & Up & HIF1A & 39 & TFCP2L1 \\
\hline Up & HIF1A & 84 & hsa-mir- $449 c-5 p$ & Up & MRPL12 & 36 & HOXC9 \\
\hline Up & CLU & 69 & hsa-mir-520a-5p & Up & $\mathrm{U} 2 \mathrm{AF} 2$ & 34 & GATA2 \\
\hline Up & $\mathrm{U} 2 \mathrm{AF} 2$ & 56 & hsa-mir-3144-5p & Up & RELA & 34 & FOXO3 \\
\hline Up & OCRL & 55 & hsa-mir-95-5p & Up & PPP1CC & 32 & SOX2 \\
\hline Up & PPPICC & 49 & hsa-mir-4643 & Up & ADRB2 & 27 & GATA1 \\
\hline Up & RELA & 41 & hsa-mir-1303 & Up & ERBB3 & 25 & STAT1 \\
\hline Up & ERBB3 & 40 & hsa-mir-4732-5p & Up & SNCA & 25 & RUNX2 \\
\hline Up & JUN & 38 & hsa-mir-3178 & Up & CD81 & 22 & XRN2 \\
\hline Up & CD81 & 23 & hsa-mir-552-3p & Up & SDHA & 22 & ESR1 \\
\hline Up & POLR2A & 16 & hsa-mir-744-5p & Up & VCAM1 & 16 & ЕР300 \\
\hline Up & SDHA & 5 & hsa-mir-760 & Up & ALB & 12 & STAT3 \\
\hline Up & SNCA & 4 & hsa-mir-7-5p & Up & OCRL & 9 & TEAD4 \\
\hline Down & CDK1 & 52 & hsa-mir-410-3p & Down & RPTOR & 52 & TBX3 \\
\hline Down & CHEK1 & 52 & hsa-mir-3941 & Down & FN1 & 46 & ATF3 \\
\hline Down & TK1 & 45 & hsa-mir-181d-3p & Down & ANLN & 42 & GATA4 \\
\hline Down & KIT & 25 & hsa-mir-181c-5p & Down & MME & 31 & PAX6 \\
\hline Down & TOP2A & 17 & hsa-mir-708-5p & Down & HEY1 & 28 & FOXP1 \\
\hline Down & FN1 & 8 & hsa-mir-140-3p & Down & TK1 & 28 & SOX11 \\
\hline
\end{tabular}




$\begin{array}{lccccccc}\text { Down } & \text { MCM6 } & 6 & \text { hsa-mir-34a-5p } & \text { Down } & \text { PTN } & 27 & \text { SOX17 } \\ \text { Down } & \text { ANLN } & 5 & \text { hsa-mir-497-5p } & \text { Down } & \text { CHEK1 } & 27 & \text { HOXB4 } \\ \text { Down } & \text { HEY1 } & 4 & \text { hsa-mir-30b-5p } & \text { Down } & \text { TOP2A } & 25 & \text { RUNX1 } \\ \text { Down } & \text { RPTOR } & 3 & \text { hsa-mir-27a-3p } & \text { Down } & \text { MCM6 } & 24 & \text { HNF4A } \\ \text { Down } & \text { A2M } & 3 & \text { hsa-mir-98-5p } & \text { Down } & \text { FLNC } & 21 & \text { RNF2 } \\ \text { Down } & \text { MME } & 2 & \text { hsa-mir-1-3p } & \text { Down } & \text { CDK1 } & 19 & \text { FOXM1 } \\ \text { Down } & \text { FLNC } & 2 & \text { hsa-mir-454-3p } & \text { Down } & \text { RIPK3 } & 16 & \text { NACC1 } \\ \text { Down } & \text { PTN } & 1 & \text { hsa-mir-155-5p } & \text { Down } & \text { A2M } & 14 & \text { FOXA2 } \\ \text { Down } & \text { ACTA2 } & 1 & \text { hsa-mir-484 } & \text { Down } & \text { ACTA2 } & 14 & \text { SMAD4 }\end{array}$

\section{Figures}

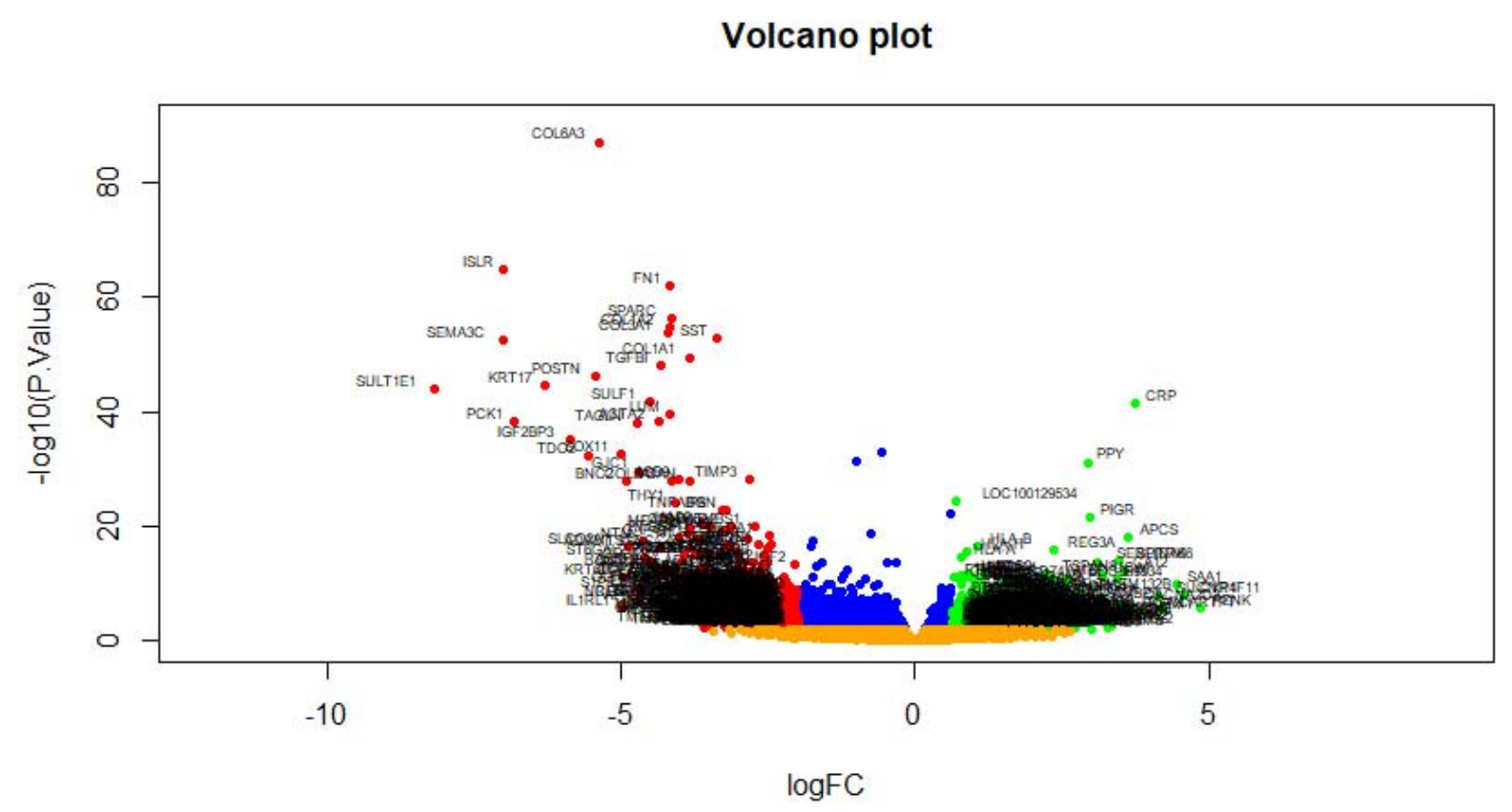

Fig. 1. Volcano plot of differentially expressed genes. Genes with a significant change of more than two-fold were selected. Green dot represented up regulated significant genes and red dot represented down regulated significant genes. 
bioRxiv preprint doi: https://doi.org/10.1101/2021.03.28.437386; this version posted May 10, 2021. The copyright holder for this preprint (which was not certified by peer review) is the author/funder. All rights reserved. No reuse allowed without permission.
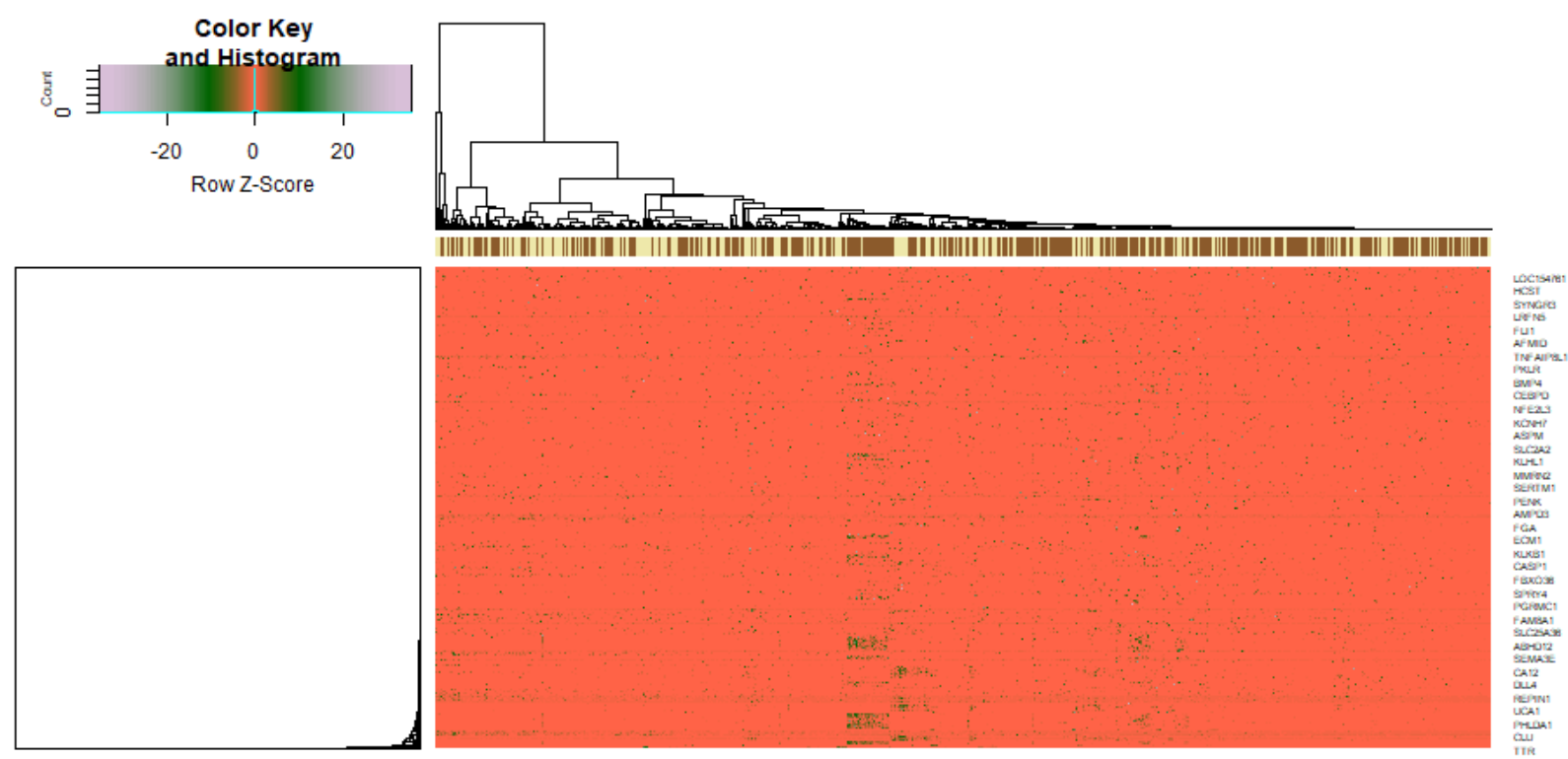

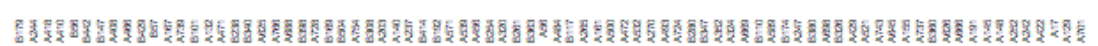

Fig. 2. Heat map of differentially expressed genes. Legend on the top left indicate log fold change of genes. (A1 A508 = normal control; B1 - B508 $=$ T2DM)

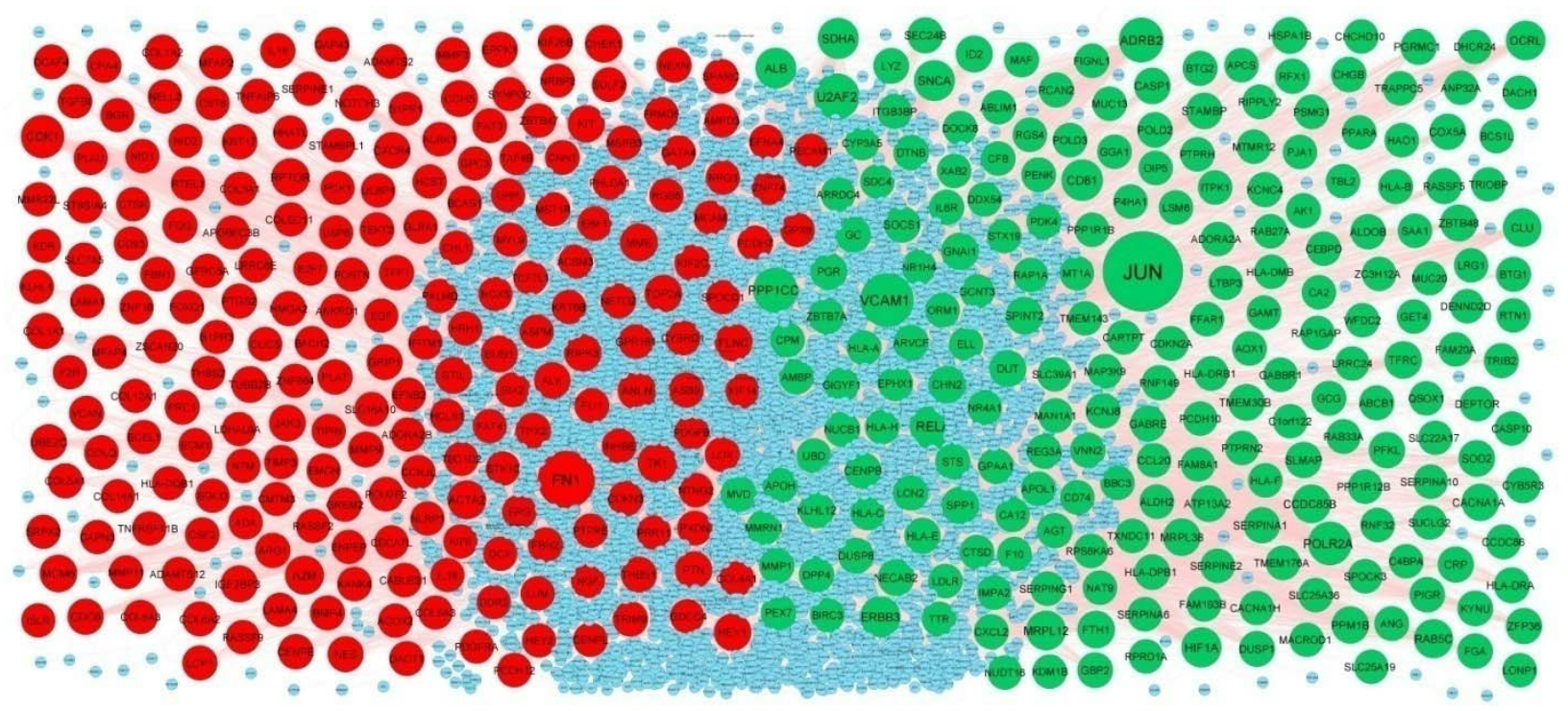

Fig. 3. PPI network of DEGs. The PPI network of DEGs was constructed using Cytoscap. Up regulated genes are marked in green; down regulated genes are marked in red 
A

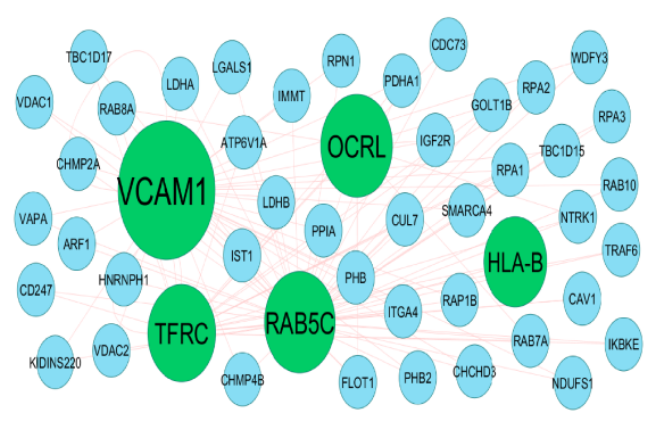

B

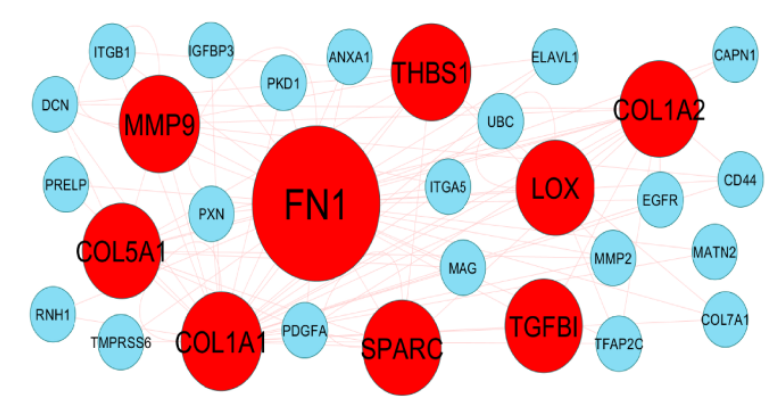

Fig. 4. Modules of isolated form PPI of DEGs. (A) The most significant module was obtained from PPI network with 48 nodes and 104 edges for up regulated genes (B) The most significant module was obtained from PPI network with 30 nodes and 92 edges for down regulated genes. Up regulated genes are marked in green; down regulated genes are marked in red.

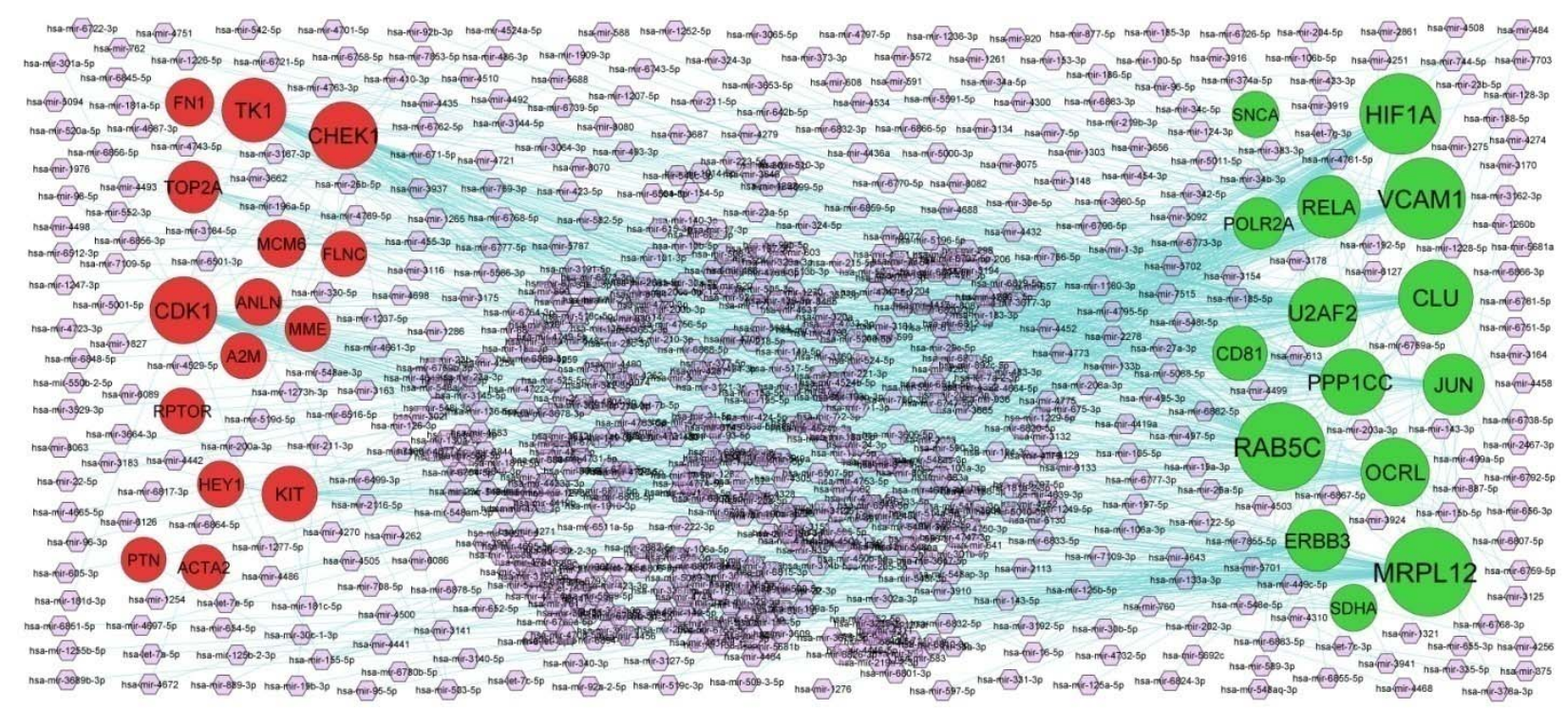

Fig. 5. MiRNA - hub gene regulatory network. The purple color diamond nodes represent the key miRNAs; up regulated genes are marked in green; down regulated genes are marked in red. 


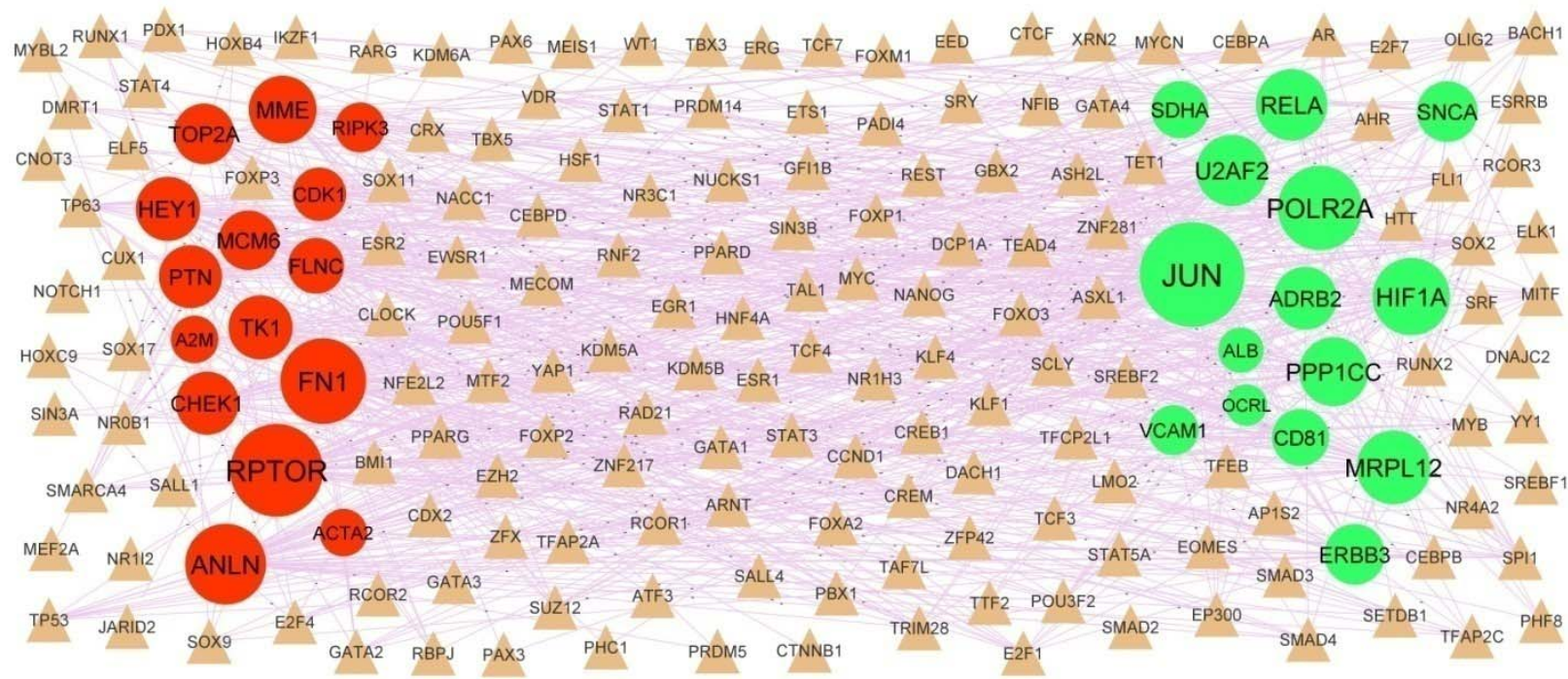

Fig. 6. TF - hub gene regulatory network. The brown color triangle nodes represent the key TFs; up regulated genes are marked in green; down regulated genes are marked in red.
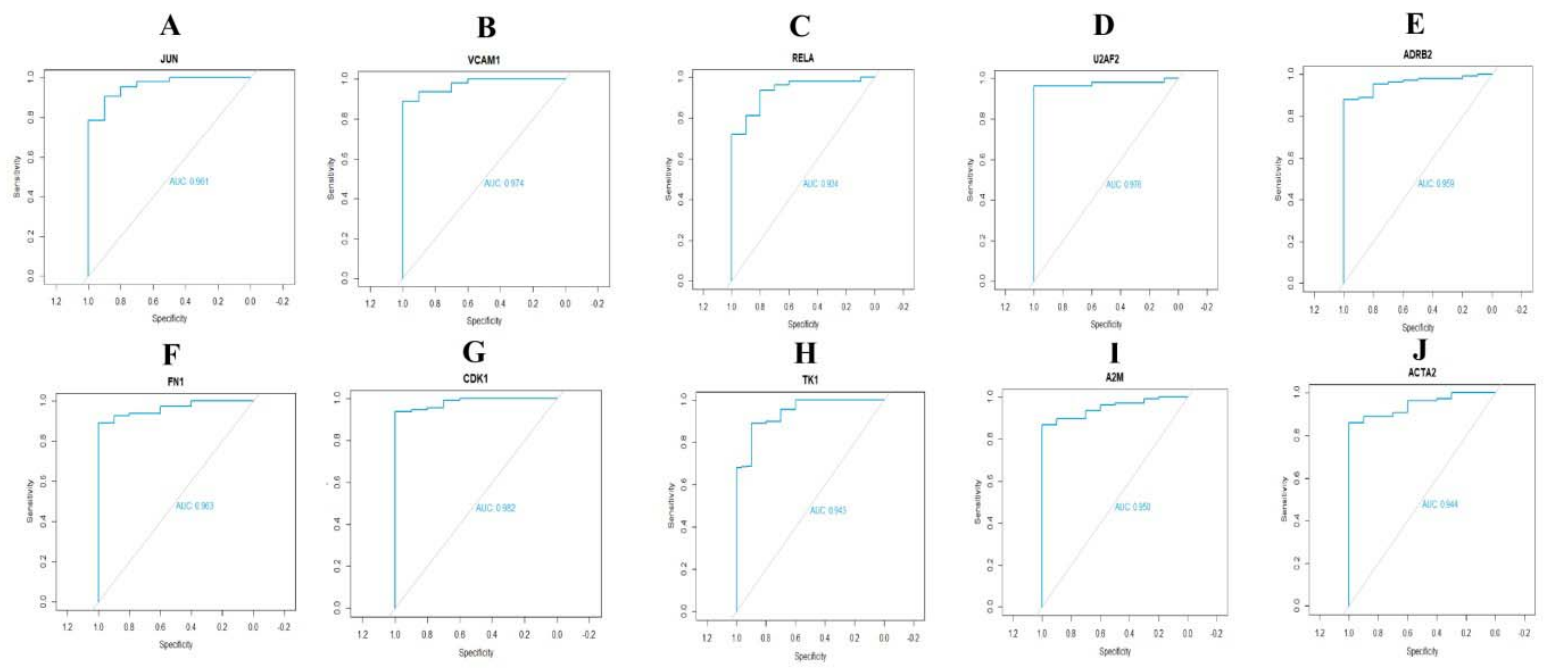

Fig. 7 ROC curve validated the sensitivity, specificity of hub genes as a predictive biomarker for T2DM prognosis. A) JUN B) VCAM1C) RELA D) U2AF2 E) ADRB2 F) FN1 G) CDK1 H) TK1 I) A2M J) ACTA2 
bioRxiv preprint dol: https://doi.org/10.1101/2021.03.28.437386; this version posted May 10, 2021. The copyright holder for this preprint (which was not certified by peer review) is the author/funder. All rights reserved. No reuse allowed without permission.
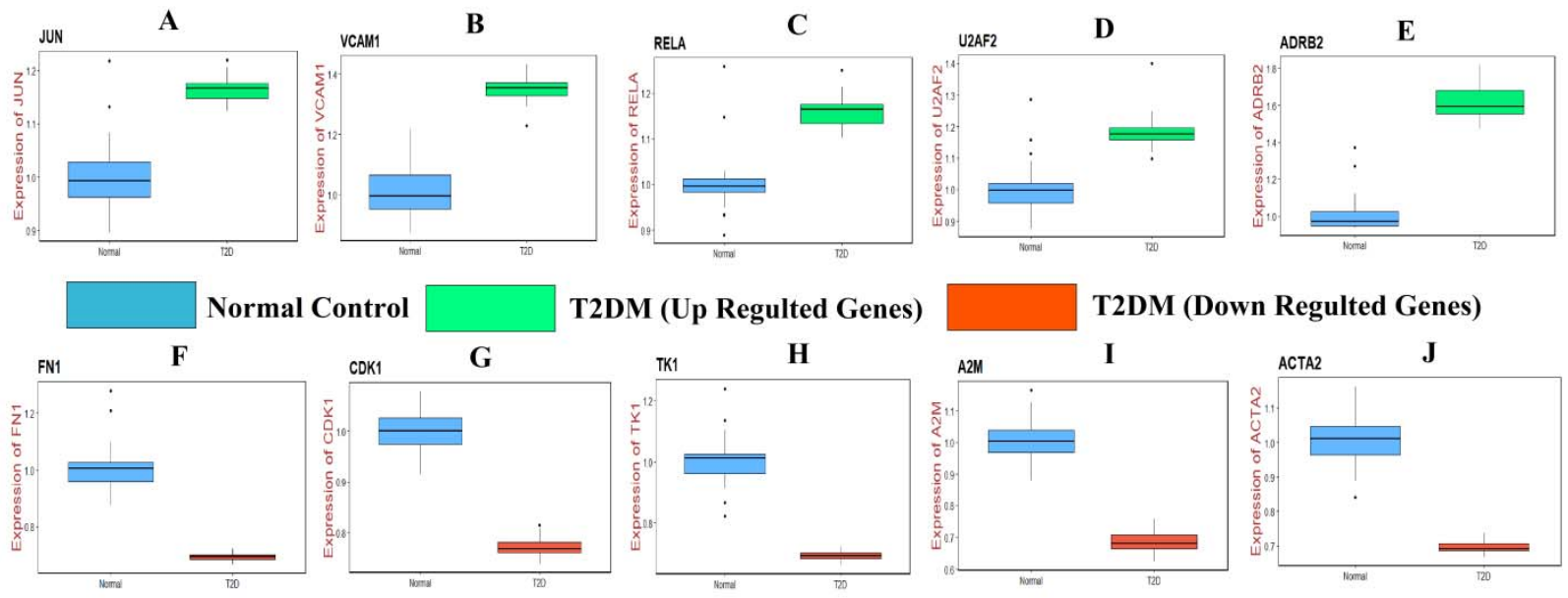

(Up Regulted Genes)
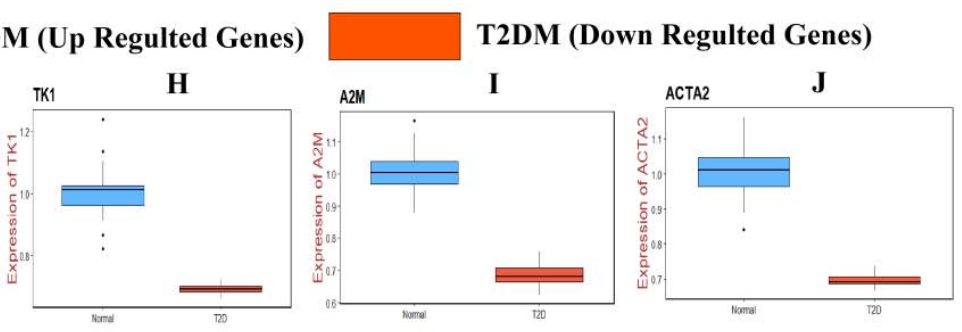

Fig. 8 Validation of hub genes by RT- PCR. A) JUN B) VCAM1C) RELA D) U2AF2 E) ADRB2 F) FN1 G) CDK1 H) TK1 I) A2M J) ACTA2 